\title{
1127
}

SoEP papers

on Multidisciplinary Panel Data Research

\section{Do You Really Want to Share Everything? The Wellbeing of Work-Linked Couples}


This series presents research findings based either directly on data from the German SocioEconomic Panel (SOEP) or using SOEP data as part of an internationally comparable data set (e.g. CNEF, ECHP, LIS, LWS, CHER/PACO). SOEP is a truly multidisciplinary household panel study covering a wide range of social and behavioral sciences: economics, sociology, psychology, survey methodology, econometrics and applied statistics, educational science, political science, public health, behavioral genetics, demography, geography, and sport science.

The decision to publish a submission in SOEPpapers is made by a board of editors chosen by the DIW Berlin to represent the wide range of disciplines covered by SOEP. There is no external referee process and papers are either accepted or rejected without revision. Papers appear in this series as works in progress and may also appear elsewhere. They often represent preliminary studies and are circulated to encourage discussion. Citation of such a paper should account for its provisional character. A revised version may be requested from the author directly.

Any opinions expressed in this series are those of the author(s) and not those of DIW Berlin. Research disseminated by DIW Berlin may include views on public policy issues, but the institute itself takes no institutional policy positions.

The SOEPpapers are available at http://www.diw.de/soeppapers

\section{Editors:}

Jan Goebel (Spatial Economics)

Stefan Liebig (Sociology)

David Richter (Psychology)

Carsten Schröder (Public Economics)

Jürgen Schupp (Sociology)

Sabine Zinn (Statistics)

Conchita D'Ambrosio (Public Economics, DIW Research Fellow)

Denis Gerstorf (Psychology, DIW Research Fellow)

Katharina Wrohlich (Gender Economics)

Martin Kroh (Political Science, Survey Methodology)

Jörg-Peter Schräpler (Survey Methodology, DIW Research Fellow)

Thomas Siedler (Empirical Economics, DIW Research Fellow)

C. Katharina Spieß (Education and Family Economics)

Gert G. Wagner (Social Sciences)

ISSN: 1864-6689 (online)

German Socio-Economic Panel (SOEP)

DIW Berlin

Mohrenstrasse 58

10117 Berlin, Germany

Contact: soeppapers@diw.de

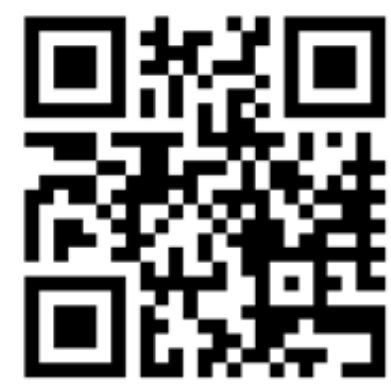




\title{
Do You Really Want to Share Everything? The Wellbeing of Work-Linked Couples *
}

\author{
Juliane Hennecke ${ }^{\dagger}$ \\ (Auckland University of Technology, IZA) \\ Clemens Hetschko \\ (University of Leeds, CESifo)
}

March 30, 2021

\begin{abstract}
Work as well as family life are crucial sources of human wellbeing, which however often interfere. This is especially so if partners work in the same occupation or industry. At the same time, being work-linked may benefit their career success. Still, surprisingly little is known about the wellbeing of work-linked couples. Our study fills this gap by examining the satisfaction differences between work-linked and non-work-linked partners. Using data from the German Socio-Economic Panel (SOEP, 2019), we estimate the effect of working in the same occupation and/or industry on life satisfaction as well as satisfaction with four areas of life: income, work, family and leisure. In the process, we employ pooled OLS estimations and instrumental variable strategies, for instance based on the gender disparity in industries and occupations. Our results suggest that being work-linked increases satisfaction with life as well as income and job satisfaction. These findings are consistent with positive assortative matching and mutual career support between work-linked partners. Our conclusions concern hiring couples as a means of recruiting exceptional talent.
\end{abstract}

Keywords: work-linked couples, wellbeing, assortative matching, relationship quality, work-life balance, copreneurs, occupational gender disparity, dual career support

JEL codes: I31, J12, J21, J44, M51

${ }^{*}$ Acknowledgements: The authors are grateful for comments made by Adrian Chadi, Alan Piper, Andreas Knabe, Clément Bellet and Jordy Meekes as well as participants of the Wellbeing Seminar at LSE (2020), the GLO/EHERO Special Sessions (2020), and the 2020 EALE/SOLE/AASLE World Conference.

${ }^{\dagger}$ Corresponding author, e-mail: juliane.hennecke@aut.ac.nz, NZ Work Research Institute, Auckland University of Technology, 120 Mayoral Drive, Auckland 1010, New Zealand. 


\section{Introduction}

Whether by meeting in college or at work, by founding a family business together, or by pure coincidence, many couples are work-linked. They have the same occupation, work in the same industry or even for the same employer. Individually, both a person's work life and relationship quality are crucial determinants of wellbeing. However, their interplay is also important. People need to reconcile family commitments and job demands on a daily basis. Having said that, surprisingly little is known about the wellbeing in couples where working life and partnership intersect. Our study fills this gap.

Understanding the determinants of individual wellbeing to improve societal welfare has become a major field of research (Weimann et al., 2015). In the process, there has been a special focus on working life due to its high relevance for both labor market and personnel policies. Happiness through, at and with work reduces absenteeism (Diestel et al. 2014) and job turnover (Clark, 2001) as well as increases performance (Oswald et al., 2015, Bellet et al. 2020). 1. To benefit wellbeing as much as possible, the workplace must not interfere with family life. (Ten Brummelhuis et al., 2014, Michel et al., 2011, Bertrand, 2013). Over the past years, the term work-life balance has become popular in the public arena and an important topic in personnel economics (e.g. Haar et al. (2014); Lauber and Storck (2019)). Employers advertise a flexible and balanced workplace to attract potential employees. The most common instruments in doing so are flexible working time, working from home as well as leave policies (Grzywacz and Carlson, 2007). Moreover, some employers support the employment prospects of the partners of highly demanded talents who need to relocate to the new workplace together with their families. If being work-linked increases wellbeing compared to a situation where both partners work in different environments, there may be a case for programs helping partners of highly demanded talents to find work in the same industry. On a more general note, positive effects of being work-linked on wellbeing may even imply an incentive for firms to hire spouses of staff members because of the many benefits of keeping workers happy. To start an evidence-based discussion of these considerations, we examine the wellbeing of partners who work in the same industry and/or occupation.

To the best of our knowledge, this study is the first that analyses the life satisfaction of worklinked partners. Economists have, so far, been more interested in the effects of different labor market states and characteristics of employment on life satisfaction, such as unemployment Clark and Oswald, 1994), job insecurity (Luechinger et al., 2010), part-time work (Booth and Van Ours, 2008), retirement (Bonsang and Klein, 2012), and self-employment (Binder and Coad, 2013) ? $^{2}$ However, there is some previous research on related outcomes in the area of management and occupational psychology, which relies on small non-representative samples (Halbesleben et al., 2010, 2012). Ferguson et al. (2016) provide a relatively extensive study with 1,278 online survey participants in which they find that

\footnotetext{
${ }^{1}$ Similarly, unhappiness predicts family life events. If the wellbeing of spouses differs to a great extent and this is driven by the wife's unhappiness, the couple are likely to divorce in the near future (Guven et al. 2012 ).

${ }^{2}$ Also, the wellbeing effects of partnership, family life and the interplay between the work and family domains have been analyzed (Lucas, 2007, Allen, 2012, Allen et al. 2014, Iseke, 2014, Knabe et al. 2016).
} 
being work-linked appears to positively correlate with job and family satisfaction. But methodological issues of endogeneity and selection remain largely unconsidered in their study.

Our study estimates the effect of being work-linked on general life satisfaction and the wellbeing in four areas of life: income, job, family, and leisure. We regard these life-domain specific indicators of wellbeing as suited for identifying the mechanisms explaining why being work-linked affects overall happiness (for a similar analysis on job loss see, e.g., Powdthavee, 2012). Positive assortative matching implies that work-linked couples are complements that generate high income and career success and thus are comparatively happy with their jobs and incomes ('power-couple hypothesis'). However, earnings risks in a work-linked couple are diversified to a lesser extent than in a non-linked couple which could have a harmful impact on wellbeing. Mutual understanding and emotional support may benefit work-life balance and thus satisfaction with family life and leisure, too. At the same time, inter alia, blurred boundaries between working life and private life imply negative effects of being work-linked. As a result of the potential for both negative and positive effects of being work-linked in the domain satisfactions, we consider the overall wellbeing effect as obtained from an estimation of life satisfaction as, a priori, unclear.

Our analyses take advantage of the extensive information available from the Socio-Economic Panel (SOEP, 2019), a large representative longitudinal household survey of the German population. The SOEP allows us to link the individuals to their partners, and contains comprehensive data on a range of characteristics for both provided they live together in the same household. By doing so, we are able to identify couples that work in the same industry or occupation and compare them to working partners that differ in these regards. For our main analyses, we define work links as the combination of occupation and industry link. SOEP data cover individuals' overall life satisfaction as well as domain-specific satisfaction measures on a yearly basis. Also, the data allow us to take into account the socio-demographic background and job characteristics of individuals, including factors that could mediate some of the impacts of being work-linked on subjective wellbeing, such as income, occupational autonomy, job security and working hours.

To identify effects of being work-linked, we employ two estimation methodologies, a pooled OLS estimation with a large number of potentially relevant covariates and, based on this, a two-stage instrumental variable estimation with endogenous binary treatment. In the process, the gender disparity in the individual's occupation and sector of industry as well as the partner's father's occupation serve us as instruments for being work-linked. Various tests do not point to a violation of the exclusion restriction.

We find that people benefit from being work-linked to their partners. Both the OLS estimation and the instrumental variable approach indicate positive effects of being work-linked on life satisfaction, income satisfaction and, to some extent, job satisfaction. While there are no significant gender differences, people who have a college degree benefit more than those without a degree. In addition, 
we obtain some evidence that income and occupational autonomy might mediate a positive impact of being work-linked. A negative effect on leisure satisfaction can only be found in the OLS estimation and is mediated by working hours. Analyses of self-employed workers and agricultural workers imply that the closest possible work link might not be the optimal, as the positive average effects do not appear in these groups.

We proceed as follows. Section 2 discusses the impact of being work-linked on wellbeing from a theoretical perspective. Section 3 describes the data, Section 4 presents our two estimation strategies. The results are documented in detail in Section 5, including the main findings, an investigation of potential mediators of being work-linked on wellbeing, subgroup analyses and sensitivity checks. Section 6 discusses our findings and concludes.

\section{Theory, mechanisms and hypotheses}

Economists have analyzed love relationships predominantly through the lens of matching on marriage markets. Work-linked partners may be seen as a form of positive assortative matching, i.e. mating of similar types, as they have chosen the same industry and/or occupation. In marriage markets, positive assortative matching occurs if partners are complements. Once the match is made, this complementarity allows couples to reach higher levels of utility, reaping a gain from marriage (Becker, 1973). Hence, a higher type individual does not only find a higher type partner, their complementarity leads to additional gains in wellbeing.

In our context, the question arises as to whether two partners who are similar, as they have the same occupation or work in the same industry, ought to be seen as complements. The work link may mean that they are better able to support each other's career, by sharing information and networks, or even through nepotism, compared to partners who have a similarly high level of skills but work in different industries and occupations. Given the complementarity, the work-linked couple may also be better able to work as copreneurs and run a business together (Blenkinsopp and Owens, 2010; Dahl et al. 2015). In any case, they may end up at a higher hierarchical level enjoying greater earnings and nonpecuniary job quality, such as occupational autonomy than a working couple that is not linked. The work-linked power couple will enjoy higher wellbeing as a result, especially in the areas of income and work.

Hypothesis (H1): Being work-linked increases income satisfaction.

Hypothesis (H2): Being work-linked increases job satisfaction.

There are a number of reasons why these hypotheses might be rejected. The gains of being worklinked may be limited to settings where career ladders are long (high-skilled professions) and require networks and other support. What is more, being work-linked correlates the earnings risks of both partners, leading to higher household income volatility. This may affect couples more the closer their 
work link, as in the case of copreneurs. In addition, nepotism might be regarded as unfair by coworkers and thus lead to worse relations with colleagues and superiors (Padgett and Morris, 2005). This would explain a negative effect in job satisfaction.

There may also be gender differences. A wage difference between work-linked partners could actually be perceived as unfair by the low-wage earner. Non-linked partners can attribute wage differences to occupation or industry effects, rather than unfair treatment. In contrast, working in the same occupation or industry as their partners enables, for instance, women to observe a gender pay gap that cannot be explained away so easily. This would result in less satisfaction with income for work-linked women. We therefore estimate the effects of being work-linked separately for men and women.

As argued by Voydanoff (2005), an understanding family environment that accommodates an individual's work demands is as important as a work environment that appreciates family demands. Being well-informed about the demands of a specific job may help workers to be more understanding towards the sacrifices their partners make for their careers when it comes to partnership and family (Ferguson et al., 2016; Halbesleben et al., 2010, 2012). Hence, the emotional support work-linked partners receive at home may lead to a better work-life balance and leave them more satisfied with their family life than non-linked partners. Also, to the extent that mutual understanding and emotional support lead to a more pleasurable time spent at home, leisure satisfaction could benefit from being work-linked to one's partner (in line with recent findings on relaxation, see Walter and Haun, 2020).

Hypothesis (H3): Being work-linked increases family life satisfaction.

Hypothesis (H4): Being work-linked increases leisure satisfaction.

Pitfalls of being work-linked in family life need to be considered, too. Partners doing similar jobs have similar working times and similar working time flexibility. As a result, not being linked might make it easier to share childcare and other family responsibilities. Partnership quality may also reduce where a close working relationship of the partners blurs the boundaries between working life and private life. In these cases, conflicts at work can all too easily spill into marital quality (Foley and Powell, 1997; Huffman et al., 2018). Occupational health literature even mentions insomnia spillovers as a particular problem of work-linked couples (Fritz et al. 2019), which can lead to low wellbeing (Piper, 2016). In this sense, not being work-linked diversifies the different risks of emotional detriment in life. It therefore remains for the empirical analysis to support or reject Hypotheses 3 and 4 .

Similarly, given the possible advantages and disadvantages of being work-linked in different areas of life, the effect on overall wellbeing as measured by life satisfaction might go both ways. We therefore do not formulate a clear hypothesis with regard to our main outcome variable and test in what follows whether positive or negative consequences prevail. 


\section{Data}

Sampling The empirical analysis makes use of 34 waves of data from the Socio-Economic Panel (SOEP, 2019) between 1985 and 2018 $3^{3}$ The SOEP is an annual representative household panel study of the German population. The most recent waves cover more than 30,000 individuals in over 15,000 households (see Goebel et al., 2019, for further information). The SOEP data have included individuals' self-reported wellbeing from the beginning as well as detailed information on their working life and partnership status. In addition, the data allow for merging partner information if couples live together in the same household which is hence a first requirement observations need to meet to be part of our sample. Some individual-year observations that fulfill this condition are still coded as one-person or single-parent households. Given this inconsistency, they are dropped from the sample. Furthermore, all couples living in stem households or other constellations with further adults are not included.

Based on this and motivated by the intended analysis, the sample is further reduced to dualearner couples. We only keep observations if the individuals as well as their partners are employed or self-employed, and of working age (25-64 years). As part of the sensitivity analyses, we include non-employed partners at a later stage (Section 5.4.

As we will explain later, our main instrumental variable works for heterosexual couples only. Therefore, we do not include same-sex partnerships. Due to the very small share of same sex couples in the full dataset (536 individuals, $0.44 \%$ of the sample), the estimation results are not sensitive to this restriction. The results of the sensitivity check can be found in Table S.1 in the Online Appendix $\mathbb{4}_{\text {. }}$ In a last step we exclude all individuals with missing information needed for the analysis (see below). This applies also to missing information on the characteristics of the partner. The final dataset consists of 122,456 observations for 24,013 individuals (i.e. 12,245 couples and households).

Occupation and industry links Our main explanatory variable is an indicator for whether an individual works in both the same occupational group as well as the same industry as their partner. We refer to these as 'combined work links' in what follows (abbreviated as WL in tables). It is assumed that, given the existence of both links, there is some overlap in the working lives or work environments of the two partners.

Occupations are categorized according to the 1992 classification by the German Federal Statistical Office (in German Klassifikation der Berufe 1992, KldB92), see Statistisches Bundesamt (2010) 5 KldB92 consists of 33 major occupations (Berufsabschnitt) which comprise 88 sub-major occupations (2-digit level, Berufsgruppe). The latter cover 369 more narrowly defined occupational groups (3digit level, Berufsordnung). Couples who are in the same occupation at that level are considered as

\footnotetext{
${ }^{3}$ The SOEP started one year before in 1984 . However, information about the type of employment contract (fixed-term or permanent) which we later use was not elicited in that year.

${ }^{4}$ The small number of same-sex couples in the data does not allow for a separate analysis.

${ }^{5}$ See Hartmann and Schütz (2017) for information on implementation in the SOEP.
} 
Table 1: Descriptive statistics - Work links

\begin{tabular}{|c|c|c|c|c|c|c|}
\hline & \multicolumn{2}{|c|}{ Combined link } & \multicolumn{2}{|c|}{ Occupation link } & \multicolumn{2}{|c|}{ Industry link } \\
\hline & No & Yes & No & Yes & No & Yes \\
\hline Observations & 116,040 & 6,416 & 114,762 & 7,694 & 99,380 & 23,076 \\
\hline$\%$ & & 5.24 & & 6.28 & & 18.84 \\
\hline Individuals & & 1,877 & & 2,283 & & 5,858 \\
\hline
\end{tabular}

Source: $[$ SOEP $[2019]$. Own calculations.

Note: Occupation links are defined at three-digit KldB92 level (369 occupations), industry-links are defined at two-digit NACE level (88 industries).

occupation-linked. At the four-digit level, three-digit occupations breakdown into 2,287 occupational classes (Berufsklassen). The four-digit level, however, produces only very few observed individuals per class. Hence, the three-digit level is the closest link we are able to analyze. To give an example, an economist who is married to a psychologist (both three-digit level occupations) is not considered work-linked although both partners are part of the same major occupation (social and teaching occupations) and the same sub-major occupation (arts and natural science professions). However, a graduate economist who is married to a graduate business economist (both four-digit level occupations) are considered occupation-linked, as both are economists (see also Table A.1 in the Appendix). If a couple also work in the same industry we consider them work-linked.

Industry sectors are compartmentalized based on the statistical classification of economic activities in the European Community (NACE). The SOEP provides these data at two levels. 21 major one-digit industries cover 88 two-digit level divisions, 58 of which are observed in the data. Cohabiting partners are considered industry-linked if their two-digit level industry matches.

Table 1 gives an overview of the numbers of observations of combined links, occupation links and industry links. $5.24 \%$ of individuals in our dataset are work-linked, as they are in the same three-digit occupational group and belong to the same two-digit industry as their partners. If we focused on separate links instead we would rely on $6.28 \%$ three-digit occupation links and $18.84 \%$ industry links. These alternative identifications of work links will be used for robustness checks later on (Section 5.4).

Table A.2 (Appendix) shows which of the major occupations (one-digit level) produce relatively many work links, such as agricultural occupations and bank/building society/insurance specialists. In contrast, work links are rare in manufacturing, building and technical professions. Similarly, Table A.3 shows for one-digit level industries that relatively many workers in the agricultural and the financial/private services sectors are work-linked, unlike in construction and manufacturing. As we will describe in greater detail below, these differences are related to gender disparities within occupations and sectors of industry (Section 4.2). In addition, Figure A.1 in the Appendix depicts all work links by major occupations and industries. Here, agriculture no longer ranks high, as only a small fraction of the workforce is employed in this industry and related occupations. Hence, for our sample, social welfare and teaching professions play a significant role, as well as the public sector, as they employ many workers and work links a relatively prevalent. 

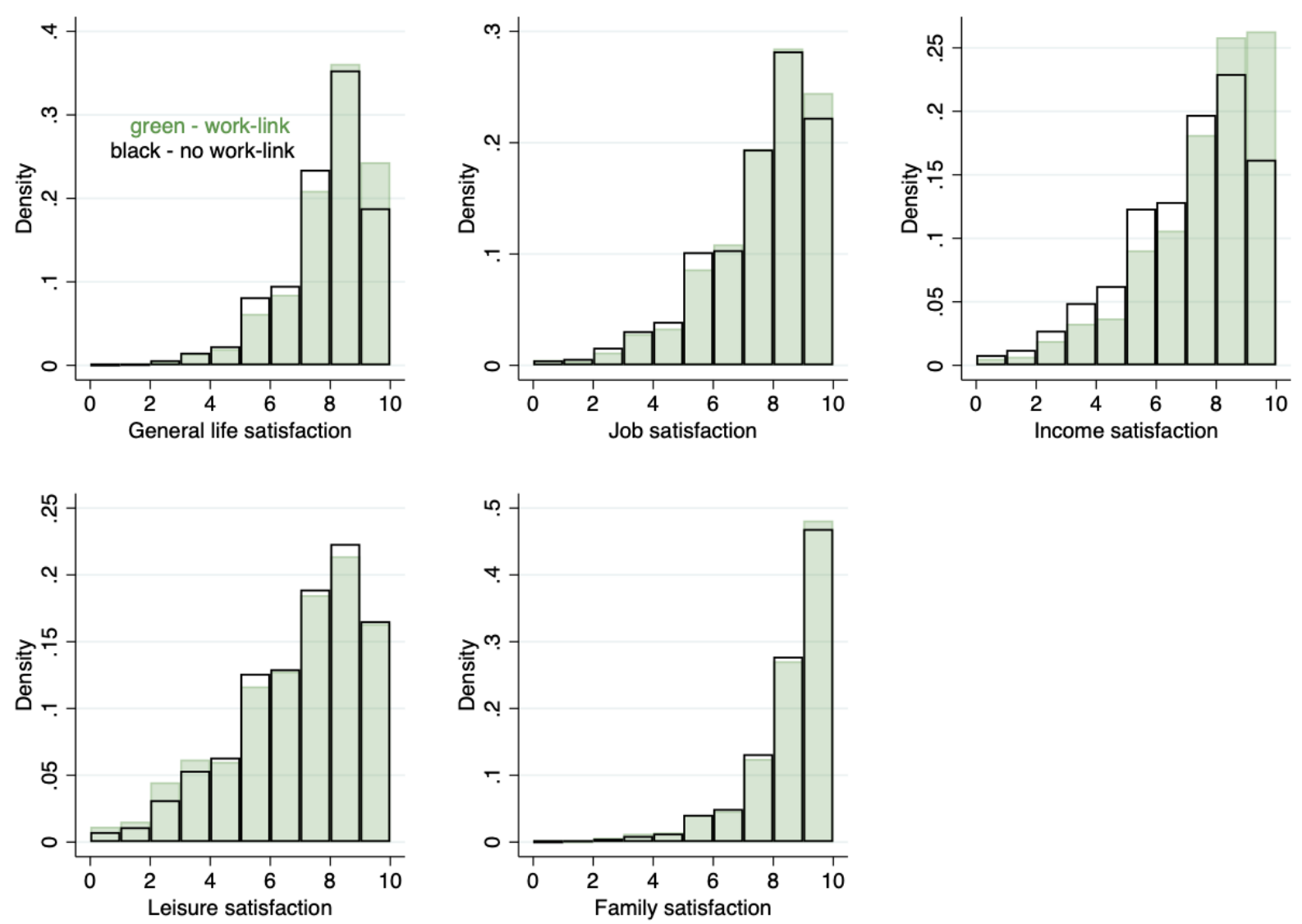

Source: SOEP 2019. Own calculations and illustration.

Subjective wellbeing To measure subjective wellbeing, SOEP respondents are asked the following question every year:

We would like to ask you about your satisfaction with your life in general. Please answer according to the following scale: 0 means 'completely dissatisfied', 10 means 'completely satisfied'. How satisfied are you with your life, all things considered?

The resulting variable is assumed to be continuous and its distribution is shown in Figure 1 and in Table A.4 in the Appendix for combined work-linked and non-linked individuals. The combined distribution is left-skewed with a mean of 7.35, a median of 8 and a standard deviation of 1.53 . As is shown in Table A.4, work-linked individuals, on average, score significantly higher on life satisfaction than non-linked individuals.

In addition to overall life satisfaction as the general wellbeing measure, individuals are required to indicate their satisfaction with a number of life domains on the same 11-point scale following the question:

How satisfied are you today with the following areas of your life? 
Our analyses consider satisfaction with job, personal income, family life and leisure, as they are most likely to reveal effects of being work-linked from a theoretical point of view (see Section 2). While job satisfaction is available for the whole time span, satisfaction with personal income (20042018), with family life (2006-2018) and with leisure (with gap $\S^{6}$ are covered in sub-periods only. The distributions of the four domain satisfactions are shown in Figure 1, too. Work-linked individuals enjoy significantly higher wellbeing than non-linked workers with respect to job and income satisfaction and lower wellbeing with respect to leisure satisfaction.

Individual, household and regional characteristics Our analyses also take into account several individual characteristics. Some of them are considered potential impacts of being work-linked, and in doing so mediators of wellbeing effects, such as monthly net individual labor income, net household equivalent income7 contractually agreed weekly working hours, subjective job security as well as occupational autonomy.

Apart from that, we make use of data on household characteristics including marital status (married or not), number of children in the household, and the partnership length in years ${ }^{8}$ Information about the federal state the individual lives in, as well as an indicator for whether the individual lives in a rural or urban area, allow for considering regional differences. Further individual characteristics used are age, gender and years of education as well as job characteristics. Job characteristics include several binary indicators, which capture whether the individual is working in the occupation they trained for, is self-employed, in fulltime employment or in a fixed-term contract. Also, we consider their tenure (in years) the size of the firm (categories small, medium and large).

Table A.5 in the Appendix gives an overview of the main characteristics of people who (do not) have a work-linked partner (Columns 2 and 3) based on the combined indicator. Work-linked individuals are on average significantly older and more highly educated, have shorter partnership lengths, are more likely to be self-employed, work in larger firms, are more likely to still work in their trained occupation, have longer tenure, work longer hours, have higher levels of occupational autonomy, and earn higher labor income as well as equivalent income.

\section{Methods}

To identify the effects of being work-linked on wellbeing, we employ two related empirical strategies. First, we pool the data over various waves and start with an OLS estimation relying on control variables to tackle endogeneity and selection issues. Second, we use the same dataset and employ a two-stage

\footnotetext{
${ }^{6}$ Leisure satisfaction was not surveyed in 1990 and 1995 and not at all for the individuals from the "Families in Germany" (FiD) related subsamples (L1-L3) in the years 2011-2013.

${ }^{7}$ Equivalent income is computed using the new OECD scale, i.e. 1 for the first adult in the household and 0.5 (0.3) times the number of additional household members that are at least 14 years old (younger than that).

${ }^{8}$ As the partnership length is not captured in the biographical information of first-time respondents, the information is left-censored for many of the individuals in the sample (as it just captures the time during which individuals were SOEP respondents). An indicator for whether the variable is left-censored or not is also included as a control.
} 
instrumental variable estimation to approach selection issues in a comprehensive manner. However, this also means that we estimate a local average treatment effect which does not necessarily reflect the average treatment effect of a work link. Hence, the OLS results are preferred in terms of external validity. Our interpretations will rely only on results that appear robust across both approaches.

\subsection{Ordinary least square estimation}

We estimate the effects of being work-linked on the different satisfaction outcomes using the following empirical model,

$$
W B_{i t}=\beta_{1}+\beta_{2} W L_{i t}+\beta_{3} H H C_{i t}+\beta_{4} I C_{i t}+\beta_{9} R C_{i t}+\beta_{5} P I C_{i t}+\beta_{6} O_{i t}+\beta_{7} I_{i t}+\beta_{8} T_{i}+\epsilon_{i t}
$$

where $W B_{i t}$ is the general or domain-specific satisfaction level of individual $i$ at time $t$ and $W L_{i t}$ is the indicator for whether the individual is work-linked based on the definitions above. Thus, $\beta_{2}$ is our parameter of interest.

We consider a detailed set of control variables to eliminate distortion from unobserved selection into work links (for a detailed list, see Table S.5 in the Online Appendix). The model includes the individual $\left(I C_{i t}\right)$, household $\left(H H C_{i t}\right)$ and regional characteristics $\left(R C_{i t}\right)$ introduced in the previous section. In addition, we control for a number of individual characteristics of the partner $\left(P I C_{i t}\right)$, namely years of education, tenure, whether they are working in their trained occupation, fixed-term contract and fulltime employment. As can be seen in the previous section, the probability of being work-linked varies across one-digit level industries and occupations, which may affect wellbeing for other reasons, too. Therefore, we also consider industry-fixed effects $I_{i t}$ and occupation-fixed effects $O_{i t}$ (at one-digit leve $9^{9}$, alongside time-fixed effects $T_{t}$ (wave dummies). In the following, we refer to the full set of the controls mentioned up to here as vector $\mathbf{X}_{i t}^{\prime}$ (e.g. in tables). Standard errors are clustered at the household level.

We deliberately do not control for equivalent income, personal labour income, subjective job security, occupational autonomy and working hours in the main specification, since we regard these variables as endogenous (see the discussion in Section 5.2). Accordingly, they will be analyzed separately as channels of wellbeing effects from being work-linked.

In principle, our data would allow us to conduct an individual-fixed effects estimation, too, which is fairly standard in research on wellbeing (Clark et al., 2016, Van der Zwan et al., 2018). However, we consider this type of analysis particularly susceptible to omitted variable bias in the context of our study. If being work-linked varies within the same person over time this will originate from other changes that affect wellbeing beyond the work link, such as changes in partnership, in one's own

\footnotetext{
${ }^{9}$ To avoid multicollinearity, we do not control for occupations and industries at the same more detailed level that we use to define the work link. This might not necessarily be a problem. The one-digit level occupation-fixed effects and industry-fixed effects hardly change the coefficients of being work-linked anymore if all other control variables are considered, implying that occupation and industry affect the work link wellbeing relationship indirectly through other factors which have been taken into account.
} 
working life or the partner's working life (Clark and Georgellis, 2013, Chadi and Hetschko, 2018; Nikolova and Ayhan, 2019). Controlling for all of these changes would also capture any variation in being work-linked, preventing us from estimating the effect of interest. Hence, in our context, a fixed-effects approach is of no value beyond the cross-sectional analysis described above.

\subsection{Instrumental variables}

The simple OLS framework might not capture all characteristics correlating with being work-linked and wellbeing and it does not account for reversed causality, i.e. happier people might be more likely to find a partner at work. We address the problems with exogenous instrumental variables $\left(z_{i t}\right)$.

Gender disparities (IV 1) The first instrument $z_{i t}$ denotes the average of the gender disparities in the individual's three-digit occupation and two-digit industry (recall that we focus on the combined link). Our results also hold if we use occupational gender disparity only to instrument the combined work link. The notion here is that heterosexual couples are more likely to form in occupations and industries in which the gender disparity is low. In a group of 50 male and 50 female teachers (no gender disparity) we can expect a maximum of 50 pairs whereas in a group of 99 male and one female miner, we can expect a maximum of one such pair. Obviously, this notion only applies to heterosexual couples which is why we excluded same-sex relationships from our sample. Also, this means that we approximate the probability of being work-linked for each individual at the level of their industry and occupation only. Alternatively, we could have assigned the individual probability of being work-linked based on the worker's gender in combination with the gender disparity in their industry and occupation, i.e. the female miner having a high chance of marrying a male miner but the male miner having a low chance of marrying a female miner. However, we expect an issue with the exclusion restriction here, as people might choose occupations / industries depending on the number of potential partners. People behaving in this way could be special in other respects, too.

We merge our dataset with administrative data from the German Federal Employment Agency (Bundesagentur für Arbeit) about the gender shares in industries and occupations as of 31 March 2016 for the universe of the German workforce (Bundeagentur für Arbeit, 2016a b) 10 This instrument arguably rules out reversed causality, as individual wellbeing does not affect these shares. The gender disparity $(G D)$ of industry sec or occupation occ is then calculated as

$$
\begin{aligned}
G D_{\text {sec } / \text { occ }} & =\left|50-\left(\frac{\text { females }_{\text {sec } / \text { occ }}}{\text { workforce }_{\text {sec } / \text { occ }}} \times 100\right)\right| \quad G D_{\text {sec } / \text { occ }}=[0,50] \\
z_{i t} & =\left(G D_{\text {sec }}+G D_{\text {occ }}\right) / 2
\end{aligned}
$$

\footnotetext{
${ }^{10}$ Ideally, we would calculate the gender disparity at when partners meet. However, this is not possible due to a lack of information. But, as the relative shares of females and males barely changed within occupations over time, the disparity as of 2016 is indicative of the disparity at each other point in time. This is shown by Figure S.2 in the Online Appendix for female shares in 2-digit KldB occupations between 1999 and 2016 based on administrative records of the Federal Employment Agency.
} 
Figure 2 illustrates the relationship between the occupational/industrial gender disparity and the probability of being work-linked.

Figure 2: Kernel densities of occupational/industrial gender disparity

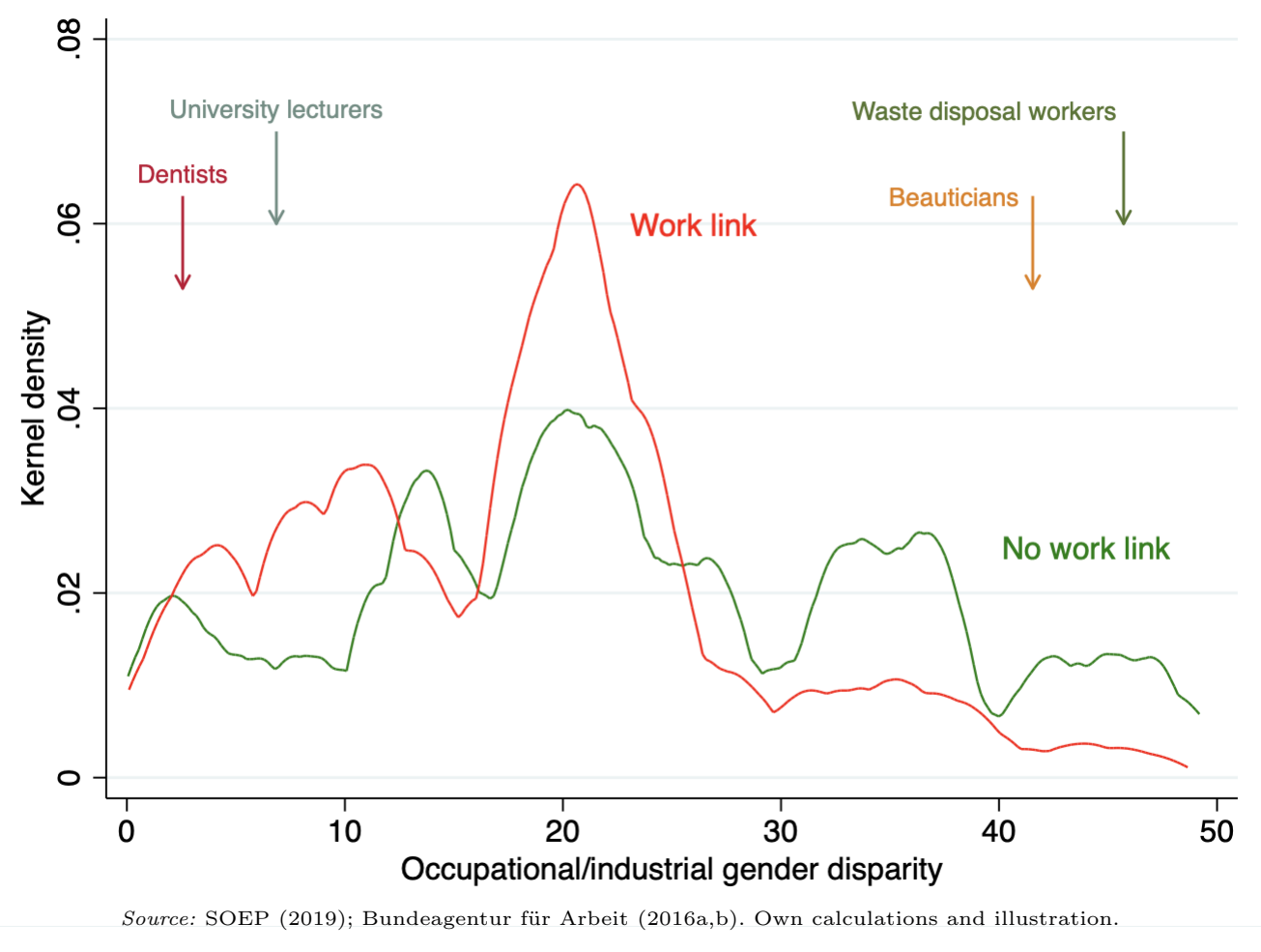

Intergenerational transmission of occupational choice (IV2) The second instrument $z_{i t}$ is the current overall work link probability in the occupation the partner's father pursued when the partner was 15 years old (retrieved from the biographical information). We use paternal occupation only due to a very high number of missing occupations for mothers $(>60 \%)$. The instrument is based on the idea of intergenerational transmission of occupational choice (Kelly et al., 2014). The fact that occupational choice often depends on parents' occupation also implies that being work-linked does not only depend on one's own parents' occupation, but also on that of the partner's parents. Arguably, this is independent of one's own wellbeing in a reversed causality sense and unlikely to impact wellbeing beyond the probability of being work-linked. We further discuss the exclusion restriction for both instruments below.

The work link probability of the partner's paternal occupation is the current share of work links in the partner's father's occupation (in \%). The share is estimated based on the mean of the work link indicator per occupation in the current SOEP wave. We cannot identify this probability for $20 \%$ of the sample, as, for instance, some observations are missing information on the partner's father's professional status or because the father was not working when the partner was 15 years old. The estimation sample thus reduces to individuals for whom we are able to identify the partner's father's 
Table 2: First stage estimation results - Full sample

\begin{tabular}{|c|c|c|c|}
\hline & All & Men & Women \\
\hline Occupational/industrial gender disparity & $\begin{array}{l}-0.011^{* * *} \\
(0.003)\end{array}$ & $\begin{array}{l}-0.015^{* * *} \\
(0.003)\end{array}$ & $\begin{array}{l}-0.006 \\
(0.004)\end{array}$ \\
\hline F-statistic & 10.13 & 17.16 & 1.99 \\
\hline $\mathrm{N}$ & 122,456 & 61,228 & 61,228 \\
\hline $\mathrm{P}(\mathrm{WL})$ in partner's paternal occupation in \% & $\begin{array}{l}0.010^{* * *} \\
(0.002)\end{array}$ & $\begin{array}{l}0.008 * * * \\
(0.003)\end{array}$ & $\begin{array}{l}0.011^{* * *} \\
(0.003)\end{array}$ \\
\hline F-statistic & 16.01 & 5.95 & 11.20 \\
\hline $\mathrm{N}$ & 98,153 & 49,406 & 48,747 \\
\hline $\mathbf{X}_{i t}$ & $\checkmark$ & $\checkmark$ & $\checkmark$ \\
\hline
\end{tabular}

occupation 11

Estimation model We separately estimate a linear regression model with endogenous binary treatment for both instruments using the Maximum Likelihood Estimator (STATA command etregress) ${ }^{12}$

$$
\begin{aligned}
W B_{i t} & =\beta_{1} W L_{i t}+\mathbf{X}_{i t}^{\prime} \beta_{2}+\epsilon_{i t} \\
W L_{i t}^{*} & =\mathbf{X}_{i t}^{\prime} \pi_{1}+\pi_{2} z_{i t}+v_{i t} \\
W L_{i t} & = \begin{cases}1 & \text { if } W L_{i t}^{*}>0 \\
0 & \text { otherwise }\end{cases}
\end{aligned}
$$

$\mathbf{X}_{i t}^{\prime}$ comprises the same control variables as the simple OLS estimation from before (Section 4.1). Standard errors are clustered at the grouped occupation and industry level for IV1 and at the household level for IV2.

Table 2 presents the results of the first-stage estimations for both instruments, the full sample and gender subsamples ${ }^{13}$ The instruments correlate with being work-linked as expected. For men, gender disparity is the stronger instrument than the work link probability in partner's paternal occupation. This is probably because of the weaker link between a father's occupation and his daughter's (the man's partner) occupational choice. As mentioned above, mother's occupation is not a sufficient replacement due to many missing values. As opposed to this, for women the work link probability in partner's paternal occupation is observed to be the better instrument.

\footnotetext{
${ }^{11}$ In order to enable comparability, we check the sensitivity of the OLS and the IV 1 estimations to this sample restriction, too. The results are robust and are presented in Table S.1 in the Online Appendix.

${ }^{12}$ In the present model, etregress is preferred to a two-stage least squares (2SLS) approach as the binary and rare nature of our treatment leads to inflated estimators in 2SLS due to a violation of the linearity assumption in the first stage. Additionally, as opposed to etregress, 2SLS does not allow us to include different sets of control variables for first and second stage, which is crucial in our case as the variation in our first instrument comes from the variation in occupations/ industries and controlling for them in the first stage strips the instrument of its explanatory power. Nevertheless, the qualitative findings of 2SLS and etregress are the same, with etregress yielding the more conservative estimates.

${ }^{13}$ First stage estimation results for the reduced sample sizes corresponding to family, leisure and income satisfaction can be found in Table $\mathrm{S.2}$ in the Online Appendix.
} 
Table S.3 in the Online Appendix presents results for the tF test procedures for weak instrument based on Lee et al. (2020). Except for family satisfaction as well as for life satisfaction in the subsample of women, all results presented in the following hold also if tF corrected standard errors are computed.

Exclusion restriction For the exclusion restriction to hold, the gender disparity in the individual's occupation and industry must not directly impact wellbeing i.e. $\operatorname{Cov}\left(z_{i t}, \epsilon_{i t}\right)=0$. Although this assumption cannot be be formally tested, we perform a number of ancillary analysis in order to support the assumption. Indeed, we find no statistically significant association (i.e., at $p<0.05$ ) between the gender disparity and our indicators of satisfaction in the reduced-form OLS regression where we control for the work link indicator (see Table S.4. Online Appendix). Moreover, we control for all variables from before which may capture other channels from the gender disparity to wellbeing. In the process, controlling for the industry and the occupation at a more aggregate level (first-digit) eliminates bias from the fact that occupations and industries with a relatively high or low gender disparity may differ in other respects, too. Controlling for the major industry and occupation also addresses the potential problem that comparatively happy or unhappy individuals select into more gender-equal or gender-unequal occupations and industries. Again, this should lead to a correlation between wellbeing and the gender disparity which we do not find. In addition, we analyze a subsample of individuals that we observe at age 17 and test whether their life satisfaction correlates with the gender disparity in their first occupation or industry. This is not the case (see Figure S.1 in the Online Appendix). In this regard, we should keep in mind that the gender disparity is only low if there are equal shares of both genders.

When it comes to the occupation of the individual's partner's father the same arguments apply. The probability of being work-linked of the partner's father is not correlated with individual wellbeing in the reduced form equation (at least not at $p<0.05$, see Table S.4. Online Appendix). The many control variables included, particularly those for occupation and industry, should further alleviate such concerns. Finally, having two instruments that are at least notionally independent of each other but nevertheless produce similar second-stage results is also reassuring (see Section 5.1).

\section{Results}

\subsection{Main results}

In the first step, we present the findings for the whole sample as well as the two gender subsamples. The estimates of being work-linked are presented in Figures 3 and 4 as well as in Table A.6(Appendix). Full estimation results, which include the coefficients for all control variables, are presented in Table S.5 and Table S.6 in the Online Appendix. We distinguish between unconditional (excludes control variables) OLS estimates, conditional OLS estimates and the second-stage IV estimates for the two instruments. 


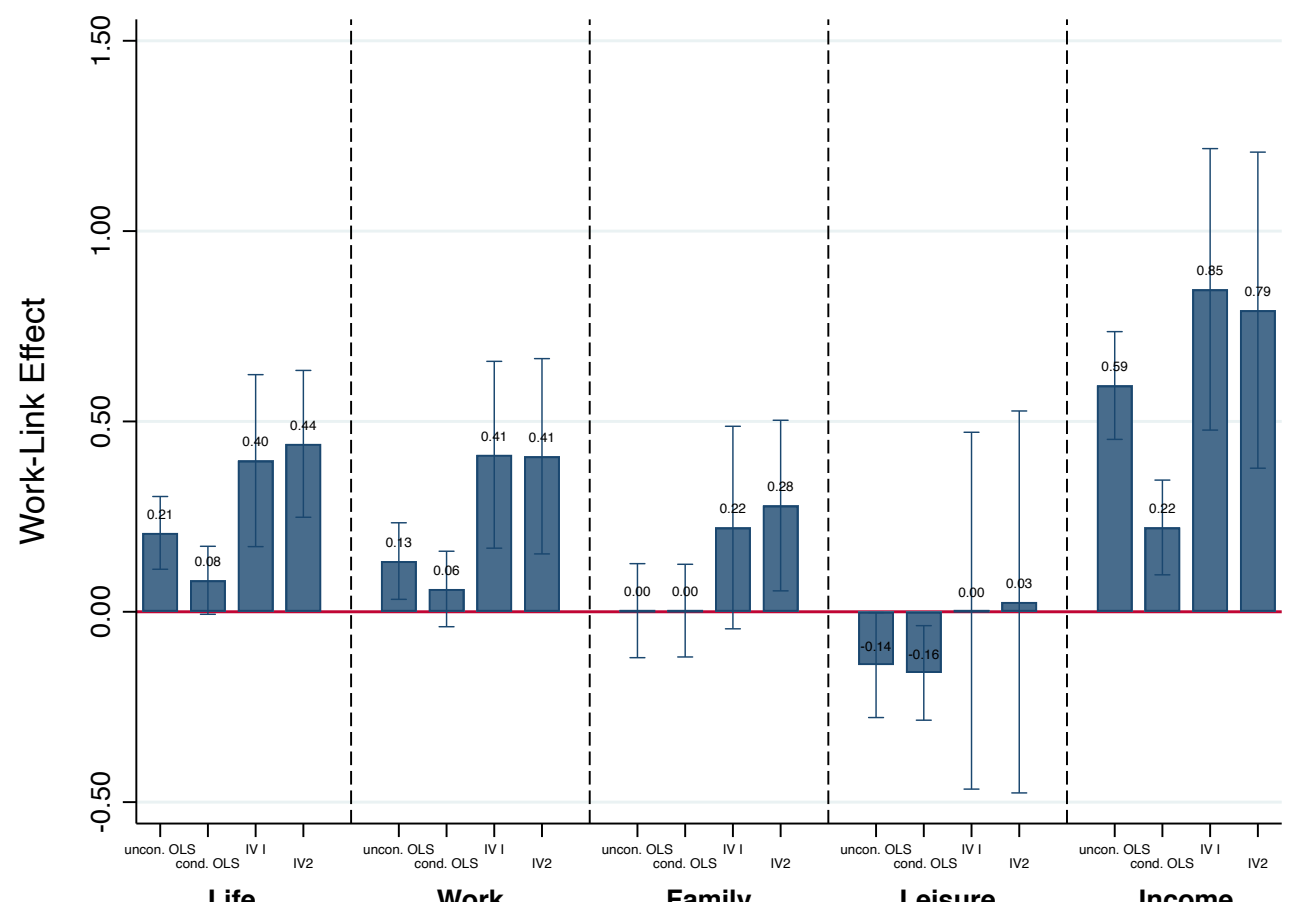

Source: SOEP 2019); Bundeagentur für Arbeit 2016a|b]. Own calculations and illustration. Note: Confidence intervals are based on standard errors clustered at the occupation/industry or household level and refer to the 95 percentile. Corresponding estimation coefficients can be found in Table A.6 (Appendix). Conditional results and IV estimates are based on the full set of controls (vector $\mathbf{X}_{i t}^{\prime}$ ). Specifications for estimations using IV 2 without federal state indicators due to non-convergence.

It turns out that both genders benefit from being work-linked to their partners in terms of life satisfaction and income satisfaction (i.e., in support of Hypothesis 1). When it comes to the OLS estimations, controlling for the characteristics as described in equation 4.1 reduces the effect size. The IV estimates of being work-linked on life satisfaction and income satisfaction are generally larger than the OLS coefficients and are fairly similar despite the use of two independent instruments.

The income satisfaction effects appear particularly strong (ranging from 10 to $40 \%$ of a standard deviation), pointing to a positive impact of being work-linked on career success. There is also weak evidence for a positive effect of being work-linked on job satisfaction (IV only), lending some support to Hypothesis 2. The effect seems to be stronger for women but the gender difference is not statistically significant. Life satisfaction is often regarded as a summary measure of the domain satisfactions (Van Praag et al., 2003; Chadi and Hetschko, 2020). This idea is compatible with our results that entail large positive effects of being work-linked in some life domains (e.g. income), but much lower effects in others (e.g. leisure), and a life satisfaction effect ranging somewhere in-between (ranging from 6 to $27 \%$ of a standard deviation). The fact that income satisfaction seems to be a relatively responsive wellbeing outcome is also in line with previous literature (Powdthavee, 2012; Chadi and Hetschko, 2017). Our estimations do not consistently reveal positive effects of being work-linked in satisfaction with family life (i.e., there is no clear support of Hypothesis 3). There is a negative correlation between 
Figure 4: Estimation results - Gender differences
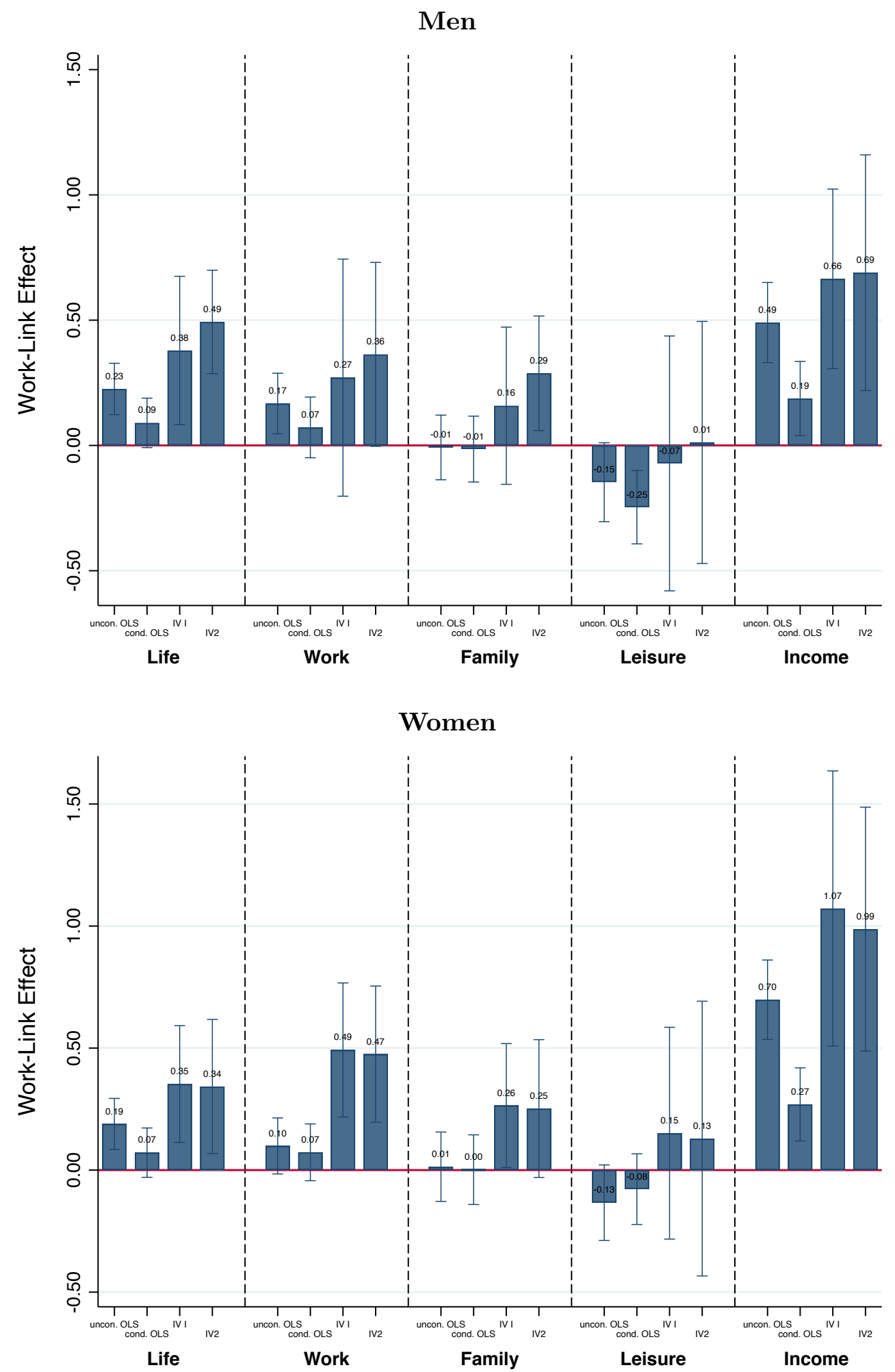

Source: SOEP 2019]; Bundeagentur für Arbeit 2016a b). Own calculations and illustration. Note: Confidence intervals are based on standard errors

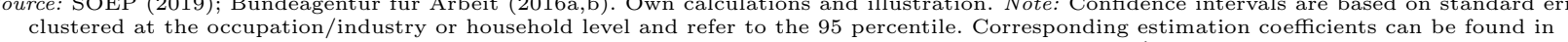
Table A.6 (Appendix). Conditional results and IV estimates are based on the full set of controls (vector $\mathbf{X}_{i t}^{\prime}$ ). Specifications for estimations using IV 2 without federal state indicators due to non-convergence. 
being work-linked and leisure satisfaction according to the OLS results, which is significantly stronger in men than in women. However, the IV also do not show positive effects when it comes to wellbeing in the leisure domain, which means that, overall, Hypothesis 4 is rejected.

Statistically significant gender differences are rare. Women and men both benefit from being worklinked. Given the different issues with the two methodologies (generalizability of IV, potential for endogeneity problems in OLS), we would not want to place much emphasis on the relatively small differences in effect sizes between genders. We analyze effect heterogeneity further below (Section 5.3).

\subsection{Autonomy, job security, income and hours as mediators}

In order to identify important channels of the identified relationships, we separately include a number of endogenous variables into the main specification, namely occupational autonomy, subjective job security, equivalent income and labor income, as well as working hours. According to our results, positive effects of being work-linked dominate in satisfaction with life and income and female's job satisfaction. These results support the power-couple hypothesis (Section 2 which posits that work-linked partners help each other climb the career ladder and therefore gain satisfaction. Therefore, occupational autonomy which reflects success on the career ladder may mediate the impact of being work-linked on wellbeing. As illustrated in the first column of Table 3 a work link increases occupational autonomy according to a conditional OLS estimations that replace satisfaction by autonomy as outcome variable. Including autonomy as additional control variable in the OLS estimation as well as the second stage of the IV estimations of satisfaction outcomes (Table A.7 in the Appendix) however hardly reduces the wellbeing effects of being work-linked.

If being work-linked fostered career success we should also observe positive income effects on the household level (equivalent income) and in individual earnings (labor income). This view is supported by the results in Table 3 (Columns 3 and 4). As for occupational autonomy, we find that the wellbeing effects of being work-linked reduce slightly once we control for equivalent income and labor income (Table A.7 in the Appendix).

Table 3: Effect of work link on endogenous variables (conditional OLS)

\begin{tabular}{|c|c|c|c|c|c|}
\hline$Y_{i t}$ & $\begin{array}{l}\text { Occ. auton. } \\
\text { High (dum) }\end{array}$ & $\begin{array}{l}\log (\text { net } H H \\
\text { eq. inc. })\end{array}$ & $\log ($ income $)$ & $\begin{array}{l}\text { Working } \\
\text { hours }\end{array}$ & $\begin{array}{c}\text { Secure } \\
\text { job }\end{array}$ \\
\hline WL & $\begin{array}{c}0.074^{* * *} \\
(0.012)\end{array}$ & $\begin{array}{c}0.040 * * * \\
(0.014)\end{array}$ & $\begin{array}{c}0.072^{* * *} \\
(0.014)\end{array}$ & $\begin{array}{c}0.991^{* * *} \\
(0.231)\end{array}$ & $\begin{array}{l}0.027^{*} \\
(0.016)\end{array}$ \\
\hline $\mathrm{N}$ & 122456 & 122276 & 122456 & 119582 & 120192 \\
\hline$X_{i t}$ & $\checkmark$ & $\checkmark$ & $\checkmark$ & $\checkmark$ & $\checkmark$ \\
\hline
\end{tabular}

Career success manifests itself in non-pecuniary ways as well. Work-linked partners may be better able than others to land a fulltime job and thus not end up underemployed. Moreover, working many hours could be particularly enjoyable for work-linked partners in cases of close links where time spent 
at work is to some extent spent with the partner (running a business together, farming, being employed by the same company). For these reasons, we repeat the two kinds of mediator analysis (mediator as outcome in Table 3 , mediator as control variable in Table A.7 for the contractually agreed weekly working hours. Being work-linked increases hours significantly. Still, the positive effects of being worklinked found in satisfaction with life, income and work do not shrink if we control for hours of work. Having said that, the negative effect of the work link on satisfaction with leisure that appears only in the OLS estimation vanishes when controlling for hours.

Lastly, we consider job security as a potential benefit of work-linked couples. It is measured using the item "How worried are you about losing your job" on a three-point scale (with a higher rating implying higher security, i.e. fewer worries). What worries people may be either the probability of losing their current job, or the consequences of job loss (Geishecker, 2012). A work link could potentially alleviate both reasons for concern. Nepotism could limit the probability of job loss, while networks and information provision may reduce the time spent unemployed and the effort necessary to find a new job in the actual event of a job loss. As shown in the final column of Table 3 , being work-linked indeed reduces concerns about job security. Its explanatory power for the work link wellbeing relationship is, however, small (Table A.7).

\subsection{Heterogeneity, closeness of the work link, gender norms and a tunnel effect}

As a next step, we examine whether certain groups of couples are driving our results. This has to rely on the OLS approach only, as the IV estimations fail to converge with many of the much smaller samples in the fully-separated models. In line with the power-couple hypothesis mutual support in working life should play a role especially in occupations with relatively long career ladders, i.e. those that require an academic degree. In panel 1 of Table A.8 (Appendix) we therefore interact the work link indicator with an indicator for whether the individual had a college degree. It turns out that all positive satisfaction effects of being work-linked are significantly higher in the former group.

Closely related to this finding, we analyze our power couple hypothesis more closely by separating high earners (net labor income greater than the 75th percentile of the distribution) and all other earners. Based on this, we differentiate between couples with two non-high-earners, couples with one high-earner (either self or the partner) and couples with two high-earners. The results of the heterogeneity analysis are presented in panel 2 of Table A.8. In line with expectations, we find a much stronger positive effect on life and job satisfaction for power couples as well as a slightly positive effect on family satisfaction, too.

We also investigate the wellbeing effects of being work-linked dependent on how the individual's income compares to their partner's income. To some extent, partners are reference points for people's own career success (Clark et al., 2003; Goerke and Pannenberg, 2015). This should especially be true for work-linked couples, as people choose reference groups by similarity. In line with the 'tunnel effect', 
higher earnings of a partner who works, for instance, in the same industry signal future increases of one's own personal income (Clark et al. 2009$)$. Hence, in a work-linked couple, someone who earns less than their partner may have higher income satisfaction than someone in the same position in a non-linked couple. Panel 7 of Table A.8 distinguishes between people that earn at least 500 euros per month less than their partners (after taxes), roughly the same as their partners (maximum deviation $=500$ euros) or at least 500 euros more than their partners. While most satisfaction effects of a work link are similar across these three groups, the positive income satisfaction effect indeed turns out to be most pronounced in those who earn less than their partners, even if household income is controlled for.

Moreover, we consider the possibility that the closest possible work link is not the optimal work link despite the positive effects found up to here. Couples may enjoy many of the advantages just by working in the same occupation or industry (spousal support, networks, information sharing), whereas some risks of being work-linked may grow if they even work for the same employer (blurred boundaries, highly correlated earnings risk). To shed some light on this possibility, we analyse work-linked couples who are self-employed, as we expect many of them to share a place of work (e.g. copreneurs). Note that our definition of self-employed workers also includes family members working in the family business. In line with the idea of links being 'too' close in some cases, self-employed workers display no positive effects of being work-linked on the satisfaction outcomes under consideration.

One sector where we expect small family businesses to be particularly prevalent is farming (Fitzgerald and Muske, 2002). We approach the issue of very close work links again through a separate estimation based on the agricultural sector, and allow for a comparison with other sectors in panel 4 of Table A.8. In line with our findings for the self-employed, the effects of being work-linked on several satisfaction outcomes are significantly smaller in this industry where partners often actually work together.

In a very traditional environment working women and their partners might suffer from deviating from the male breadwinner model. Being work-linked makes this norm deviation potentially more salient to one's own social group (such as colleagues) and thus more harmful for wellbeing. This could lead to a difference between East German and West German couples in the effects of being worklinked on wellbeing, as female labor supply was enforced in the GDR such that the male breadwinner model ceased to be a norm. Moreover, we might see increasingly positive wellbeing effects of being work-linked over time, as female labor supply has risen in general and the male breadwinner model has gone out of style (Wyrwich, 2019). But, as further subsample estimations presented in panels 5 and 6 of Table A.8 show, we cannot detect clear differences in the satisfaction effects of a work link between East and West Germans or between the pre-2000 and the post-2000 samples.

Next, we shed light on the notion that work-linked partners suffer from correlated earnings risks (see als Section 2p. If true, risk-averse work-linked indviduals should demonstrate comparatively low 
wellbeing, as they dislike being exposed to risks in life more than others. Individual willingness to take risks has been elicited in the SOEP in 2004, 2006 and annually since 2008, with a question asking respondents to rate whether they are "generally a person who is willing to take risks" on a scale from 0 to 10. We calculate the average of all indvidual observations of risk attitude during participation in the panel survey and classify respondents as either risk-averse or risk-seeking depending on whether they rank below or above the median. Panel 8 of Table A.8 reports the results of the heterogeneity analysis. Although risk seekers enjoy higher levels of wellbeing, we cannot detect any significant heterogeneity in the wellbeing effects of being work-linked between risk-seeking and risk-averse individuals.

Lastly, the effect of a work link might differ over the life course, as both partners progress on their careers and may become increasingly able to support each other. Age is usually u-shaped in wellbeing, which is why we interact the work link variable with age bands that split the sample into four ten-year brackets. The results can be found in panel 9 of Table A.8. No clear patterns emerge when it comes to satisfaction with life, leisure or income. The youngest group of adults (25-34 years) experience a statistically significant loss of family satisfaction when being work-linked. The older workers get, however, the more they benefit from a work link in this domain of life. Somewhat similar to that, the effect of the work link in job satisfaction is indistinct (insignificantly negative) in the youngest group but becomes more positive over the life course.

\subsection{Sensitivity analyses}

Link type As our first robustness check, we examine the sensitivity of our results to the definition of the work link between partners. We rerun our analyses separately for solely industry-based links (at the two-digit level) and solely occupation-based links (at the three-digit level). As can be seen in Table $\mathrm{S.7}$ in the Online Appendix, these estimations closely resemble our analyses for the combined link, including both the OLS approach as well as the IV estimates. This is not surprising given the large overlap between occupation links and industry links seen in Table 1.

Traits Secondly, we address selection issues in both the pooled OLS and the IV setting further by controlling for personality and various other traits. Personality strongly determines baseline levels of wellbeing (Lucas and Diener, 1999) and might also explain occupational choice and partner choice. A similar argument may be made with regard to risk aversion, time preference or subjective beliefs (optimism). Hence, controlling for these traits takes away an important source of heterogeneity that could explain high levels of wellbeing in work-linked couples. In the process, we consider the Big Five personality traits openness, conscientiousness, extraversion, agreeableness and neuroticism as well as locus of control, risk attitude, impatience and optimism/pessimism. The sample shrinks considerably as these traits are not elicited every year (for a more detailed account, see Online Appendix). As Table S.8 shows, our OLS and IV results barely change if we control for traits in addition to the 
variables considered in our main specification.

Correlated earnings risk Finally, we address the issue that our sampling might to some extent eliminate an important channel from being work-linked to wellbeing, the correlated earnings risk. In our main analyses, we do not consider non-employed workers who may currently suffer from income losses due to joblessness. As another check presented in Table S.1 in the Online Appendix, the sample is extended to couples where one or both partners are currently unemployed or non-working for other reasons. To still be able to identify work links, we impute occupation and industry of the non-working partners from previous waves of data. The sample comprises 122,456 individuals from dual-earner couples (original sample), 4,856 individuals from double non-working couples and 30,464 individuals from single-earner couples. The results based on the extended sample are largely in line with our previous findings, so the impact of the non-working partners is negligible (panel 1a). Then, worklinked couples with at least one non-working partner are examined only. Here, we find fewer positive effects across the different indicators of wellbeing, which could point to the problem of correlated earnings risks or simply to the fact that those who are unemployed currently do not enjoy the benefits of being work-linked (panel 1b).

\section{Concluding remarks}

Our investigation suggests that there are positive effects of being work-linked on subjective wellbeing. Most importantly, an occupation and/or industry link increases workers' satisfaction with their lives. We also find positive effects of being work-linked on income satisfaction and job satisfaction, in line with Hypotheses 1 and 2. Taken together with the benefits of a work link that we identify in income and occupational autonomy, these results point to the idea of power couples working in the same occupation or industry which enables them to greatly benefit each others' careers. In line with that, the positive role of being work-linked is most pronounced in people with a college degree where career ladders are relatively long and earnings growth is potentially steep.

Our analyses indicate that these positive effects of being work-linked are not driven by men, as increased salience of a gender pay gap in work-linked couples would have implied (see Section 2). In fact, the job satisfaction effects are even more pronounced in women. Rather, our heterogeneity analysis points to a tunnel effect benefiting the low-income earner in the couple who may perceive the higher income of the partner as a signal of future pay rises.

While we cannot rule out that women in work-linked couples are more likely to feel unfairly treated than women in non-linked couples, the positive implications of being work-linked prevail. The same applies to other potentially negative effects of a work link in the work domain, such as highly correlated earnings risks. They might reduce wellbeing to some extent or not, but in any event their impact is more than offset by the benefits the power couple enjoys. This does not apply to all work-linked 
couples, though. Copreneurs, for instance, here defined as self-employed work-linked couples, are not more satisfied with their lives, incomes or jobs than non-linked self-employed workers. This is an important finding in itself, as much of the previous literature focuses on this special kind of work link.

Our results are less conclusive regarding family life satisfaction (Hypothesis 3). Dependent on the methodological approach, we are sometimes able to report positive effects of being work-linked (IV) and sometimes not (OLS). According to our heterogeneity analysis, this might be because the work link effect on family life satisfaction is age-dependent. The suspected disadvantage of blurred boundaries between working life and family life no longer seems to dominate the advantages in terms of mutual understanding and emotional support in middle-age and older workers.

Also, the in some specifications observed positive effect of a link on family life satisfaction might merely be a spillover from wellbeing obtained in the work domain (Ilies et al., 2009). In general, the possibility of these spillovers is a limitation of our approach of revealing reasons for wellbeing effects of being work-linked through the domain satisfaction measures. However, we also have to reject Hypothesis 4, as none of our empirical approaches reveals an increase of leisure satisfaction as a result of the work link. Therefore, the positive impacts of a work link in other areas of life seem to be domainspecific. In a nutshell, all findings taken together imply that the positive impact of being work-linked on life satisfaction originates from working-life related benefits.

Our findings bear implications for hiring practice. The demand for high-skilled workers has led to transregional, or even international, markets for talents in many sectors. Here, an individual accepting a job means the whole household relocating, as commuting is often considered the less preferred option. In these instances, firms and other organizations are confronted with the challenge to offer dual career support for the partners of highly demanded talent, a topic research has touched on from different angles (Padgett and Morris, 2005; Schiebinger et al., 2008; Kojima et al., 2013; Sarpong, 2018). Job search support (same industry and beyond) and hiring couples are solutions to the problem with the result that work links between partners become closer than before, or are just being created.

Our results shed light on the potential consequences of these kinds of recruitment policies. Given the positive effects of being work-linked on wellbeing, supporting partners in the attempt to find a similar job might be conducive to worker wellbeing. It remains for future research to explore if the improvement of wellbeing translates into benefits for the firm, too, through higher commitment and job performance. Another direction for future research is to test if the closest possible link, i.e., working on the same team, is actually the optimal work link, or whether the gains of being work-linked are fully reaped through industry and occupation links. This would also provide more insight as to the optimal placement of the partner of a highly demanded talent. 


\section{Declaration}

Funding not applicable

Conflicts of interest/Competing interests non

Availability of data and material publicly available data

Code availability replication code available from authors upon request 


\section{References}

Allen, T. D. (2012). The Work-Family Role Interface: A Synthesis of the Research from Industrial and Organizational Psychology. In I. B. Weiner (ed.), Handbook of Psychology, Second Edition, 26, John Wiley \& Sons, Inc.

-, Cho, E. and Meier, L. L. (2014). Work-Family Boundary Dynamics. Annual Review of Organizational Psychology and Organizational Behavior, 1 (1), 99-121.

Becker, G. S. (1973). A Theory of Marriage: Part I. Journal of Political Economy, 81 (4), 813-846.

Bellet, C. S., De Neve, J.-E. and Ward, G. (2020). Does Employee Happiness Have an Impact on Productivity? CEP Discussion Paper No. 1655.

Bertrand, M. (2013). Career, family, and the well-being of college-educated women. American Economic Review, 103 (3), 244-250.

Binder, M. and CoAd, A. (2013). Life satisfaction and self-employment: A matching approach. Small Business Economics, 40 (4), 1009-1033.

Blenkinsopp, J. and Owens, G. (2010). At the heart of things: The role of the "married" couple in entrepreneurship and family business. International Journal of Entrepreneurial Behaviour \&6 Research, 16 (5), 357-369.

Bonsang, E. and Klein, T. J. (2012). Retirement and subjective well-being. Journal of Economic Behavior \&s Organization, 83 (3), 311-329.

Booth, A. L. and Van Ours, J. C. (2008). Job satisfaction and family happiness: The part-time work puzzle. Economic Journal, 118 (526), F77-F99.

Bundeagentur Für Arbeit (2016a). Beschäftigte nach Berufen (KldB 2010) (Quartalszahlen) Deutschland. https://statistik.arbeitsagentur.de/DE/Navigation/Statistiken/ Themen-im-Fokus/Berufe/Berufe-Nav.html, as of March 31, 2016.

Bundeagentur Für ArBeit (2016b). Beschäftigte nach Wirtschaftszweigen (WZ 2008) (Quartalszahlen) Deutschland. https://statistik.arbeitsagentur.de/DE/Navigation/Statistiken/ Themen-im-Fokus/Wirtschaftszweige/Wirtschaftszweige-Nav.html, as of March 31, 2016.

Chadi, A. and Hetschko, C. (2017). Income or leisure? On the hidden benefits of (un-)employment. IAAEU Discussion Paper 06/2017.

- and - (2018). The magic of the new: How job changes affect job satisfaction. Journal of Economics and Management Strategy, 27 (1), 23-39.

- and - (2020). How Job Changes Affect People's Lives - Evidence from Subjective Well-being Data. British Journal of Industrial Relations, in press.

Clark, A. E. (2001). What really matters in a job? Hedonic measurement using quit data. Labour Economics, 8 (2), 223-242.

-, D'Ambrosio, C. and Ghislandi, S. (2016). Adaptation to Poverty in Long-Run Panel Data. Review of Economics and Statistics, 98 (3), 591-600.

- and Georgellis, Y. (2013). Back to baseline in Britain: adaptation in the British household panel survey. Economica, 80 (319), 496-512.

-, Kristensen, N. and Westergard-Nielsen, N. (2009). Job satisfaction and co-worker wages: Status or signal? Economic Journal, 119 (536), 430-447.

— and Oswald, A. J. (1994). Unhappiness and unemployment. The Economic Journal, 104 (424), 648-659.

Clark, W. A. V., Huang, Y. and Withers, S. (2003). Does commuting distance matter? Commuting tolerance and residential change. Regional Science and Urban Economics, 33 (2), 199-221.

Dahl, M. S., Van PraAg, M. and Thompson, P. (2015). Entrepreneurial couples. In 75th Annual Meeting of the Academy of Management, AOM 2015, pp. 795-800. 
Diestel, S., Wegge, J. and Schmidt, K. H. (2014). The impact of social context on the relationship between individual job satisfaction and absenteeism: The roles of different foci of job satisfaction and work-unit absenteeism. Academy of Management Journal, 57 (2), 353-382.

Ferguson, M., Carlson, D., Kacmar, K. M. and Halbesleben, J. R. B. (2016). The Supportive Spouse at Work : Does Being Work-Linked Help? Journal of Occupational Health Psychology, 21 (1), $37-50$.

Fitzgerald, M. A. and Muske, G. (2002). Copreneurs: An Exploration and Comparison to Other Family Businesses. Family Business Review, 15 (1), 1-16.

Foley, S. and Powell, G. N. (1997). Reconceptualizing work-family conflict for business / marriage partners: a theoretical model. Journal of Small Business Management, 35 (4), 36-47.

Fritz, C., PArk, Y. and Shepherd, B. R. (2019). Workplace Incivility Ruins my Sleep and Yours: the Costs of Being in a Work-Linked Relationship. Occupational Health Science, 3 (1), 1-21.

Geishecker, I. (2012). Simultaneity bias in the analysis of perceived job insecurity and subjective well-being. Economics Letters, 116 (3), 319-321.

Goebel, J., Grabka, M. M., Liebig, S., Kroh, M., Richter, D., Schröder, C. and Schupp, J. (2019). The German Socio-Economic Panel (SOEP). Jahrbücher für Nationalökonomie und Statistik, 239 (2), 345-360.

Goerke, L. and Pannenberg, M. (2015). Direct evidence for income comparisons and subjective well-being across reference groups. Economics Letters, 137, 95-101.

Grzywacz, J. G. and Carlson, D. S. (2007). Conceptualizing Work-Family Balance: Implications for Practice and Research. Advances in Developing Human Resources, 9 (4), 455-471.

Guven, C., Senik, C. and Stichnoth, H. (2012). You can't be happier than your wife. Happiness gaps and divorce. Journal of Economic Behavior 63 Organization, 82 (1), 110-130.

Haar, J. M., Russo, M., Suñe, A. and Ollier-Malaterre, A. (2014). Outcomes of work-life balance on job satisfaction, life satisfaction and mental health: A study across seven cultures. Journal of Vocational Behavior, 85 (3), 361-373.

Halbesleben, J. R., Wheeler, A. R. and Rossi, A. M. (2012). The costs and benefits of working with one's spouse: A two-sample examination of spousal support, work-family conflict, and emotional exhaustion in work-linked relationships. Journal of Organizational Behavior, 33, 597-615.

-, Zellars, K. L., Carlson, D. S., Perrewé, P. L. and Rotondo, D. (2010). The moderating effect of work-linked couple relationships and work-family integration on the spouse instrumental support-emotional exhaustion relationship. Journal of Occupational Health Psychology, 15 (4), 371387.

Hartmann, J. and Schütz, G. (2017). Die Klassifizierung der Berufe und der Wirtschaftszweige im Sozio-oekonomischen Panel - Neuvercodung der Daten 1984-2001. SOEP Survey Papers 468 (Reprint).

Huffman, A. H., Dunbar, N., Klinefelter, Z. P. and Howes, S. S. (2018). Sharing Experiences and Stressors at Work and at Home: A Model of Work-Linked Couples. Occupational Health Science, $2(2), 157-180$.

Ilies, R., Wilson, K. S. and WagneR, D. T. (2009). The spillover of daily job satisfaction onto employees' family lives: The facilitating role of work-family integration. Academy of Management Journal, 52 (1), 87-102.

Iseke, A. (2014). The Part-Time Job Satisfaction Puzzle: Different Types of Job Discrepancies and the Moderating Effect of Family Importance. British Journal of Industrial Relations, 52 (3), 445469.

Kelly, I. R., Dave, D. M., Sindelar, J. L. and Gallo, W. T. (2014). The impact of early occupational choice on health behaviors. Review of Economics of the Household, 12 (4), 737-770.

Knabe, A., Sсhöв, R. and Weimann, J. (2016). Partnership , Gender Roles and the Well-Being Cost of Unemployment. Social Indicators Research, 129 (3), 1255-1275. 
Kojima, F., Pathak, P. A. and Roth, A. E. (2013). Matching with couples: Stability and incentives in large markets. The Quarterly Journal of Economics, 128 (4), 1585-1632.

Lauber, V. and Storck, J. (2019). Helping with the kids? How family-friendly workplaces affect parental well-being and behaviour. Oxford Economic Papers, 71 (1), 95-118.

Lee, D. L., McCrary, J., Moreira, M. J. and Porter, J. (2020). Valid t-ratio Inference for IV.

Lucas, R. E. (2007). Adaptation and the Set-Point Model of Subjective Well-Being Does Happiness Change After Major Life Events? Current Directions in Psychological Science, 16 (2), 75-79.

- and Diener, E. (1999). Personality and Subjective Well-Being. In D. Kahneman, E. Diener and N. Schwarz (eds.), Foundations of Hedonic Psychology, New York: Russell Sage, pp. 213-229.

Luechinger, S., Meier, S. and Stutzer, A. (2010). Why does unemployment hurt the employed?: Evidence from the life satisfaction gap between the public and the private sector. Journal of Human Resources, 45 (4), 998-1045.

Michel, J. S., Kotrba, L. M., Mitchelson, J. K., Clark, M. A. and Baltes, B. B. (2011). Antecedents of work-family conflict: A meta-analytic review. Journal of Organizational Behavior, $32(5), 689-725$.

Nikolova, M. and Ayhan, S. H. (2019). Your spouse is fired! How much do you care? Journal of Population Economics, 32 (3), 799-844.

Oswald, A. J., Proto, E. and Sgroi, D. (2015). Happiness and productivity. Journal of Labor Economics, 33 (4), 789-822.

Padgett, M. Y. and Morris, K. A. (2005). Keeping it "All in the Family:" Does Nepotism in the Hiring Process Really Benefit the Beneficiary? Journal of Leadership 83 Organizational Studies, $11(2), 34-45$.

PIPER, A. T. (2016). Sleep duration and life satisfaction. International Review of Economics, 63 (4), $305-325$.

Powdthavee, N. (2012). Jobless, Friendless and Broke: What Happens to Different Areas of Life Before and After Unemployment? Economica, 79 (315), 557-575.

SARPong, S. (2018). Spouses at work: Opportunity ahead. Global Business and Organizational Excellence, 37 (5), 21-28.

Schiebinger, L., Davies Henderson, A. and Gilmartin, S. (2008). Dual career couples: What universities need to know. Stanford, CA: Michelle R. Clayman Institute for Gender Research, Stanford University.

SOEP (2019). Socio Economic Panel Data: Data for years 1984-2018, version 35, Doi: 10.5684/soepcore.v35.

Statistisches Bundesamt (2010). Klassifikation der Berufe 1992 (KldB 92) - Gliederungstruktur bis zur 4 Steller-Ebene. Wiesbaden: Statistisches Bundesamt.

Ten Brummelhuis, L. L., HaAr, J. M. and Roche, M. (2014). Does Family Life Help to be a Better Leader? A Closer Look at Crossover Processes From Leaders to Followers. Personnel Psychology, 67 (4), 917-949.

Van der Zwan, P., Hessels, J. and Rietveld, C. A. (2018). Self-employment and satisfaction with life, work, and leisure. Journal of Economic Psychology, 64, 73-88.

Van Praag, B. M. S., Frijters, P. and Ferrer-i Carbonell, A. (2003). The anatomy of subjective well-being. Journal of Economic Behavior \&5 Organization, 51, 29-49.

Voydanoff, P. (2005). Toward a Conceptualization of Perceived Work-Family Fit and Balance: A Demands and Resources Approach. Journal of Marriage and Family, 67 (4), 822-836.

Walter, J. and Haun, V. C. (2020). Work-Related Spousal Support and Recovery Experiences among Dual-Earner Couples - Work-Linkage as Moderator. Occupational Health Science, 4 (3), $333-355$. 
Weimann, J., Knabe, A. and Schöв, R. (2015). Measuring happiness: The economics of well-being. MIT Press.

Wyrwich, M. (2019). Historical and current spatial differences in female labour force participation: Evidence from Germany. Papers in Regional Science, 98 (1), 211-239. 


\section{Tables and figures}

Table A.1: Occupational classification in the KldB92 example

\begin{tabular}{|c|c|c|}
\hline Digit & Code & Description \\
\hline 1 & Vh & Social and teaching occupations and other not classified arts and natural science professions \\
\hline 2 & 86 & Social welfare professions \\
\hline 3 & 861 & Social workers, social education workers \\
\hline 3 & 862 & Remedial teachers \\
\hline 3 & 863 & Early childhood teachers \\
\hline 3 & 864 & Geriatric nurses \\
\hline 3 & $\ldots$ & $\ldots$ \\
\hline 2 & 87 & Teachers \\
\hline 3 & 870 & Teachers without designation \\
\hline 3 & 871 & University lecturers \\
\hline 3 & 872 & Grammar school teachers \\
\hline 3 & 873 & Primary, junior high, secondary, special school teachers \\
\hline 3 & 874 & Vocational school teachers \\
\hline 3 & 875 & Music teachers \\
\hline 3 & 876 & Sports teachers \\
\hline 3 & 878 & Driving, traffic instructors \\
\hline 3 & 879 & Other teachers \\
\hline 2 & 88 & Arts and natural sciences professions \\
\hline 3 & 880 & Academics without designation \\
\hline 3 & 881 & Economic scientists \\
\hline 4 & 8810 & Economists without further specification \\
\hline 4 & 8812 & Graduate economists without further specification \\
\hline 4 & 8814 & Graduate business economist without further specification \\
\hline 4 & 8815 & Business economists without further specification \\
\hline 4 & $\cdots$ & $\cdots$ \\
\hline 3 & 882 & Arts and humanities academics \\
\hline 3 & 883 & Natural scientists \\
\hline 3 & 884 & Social scientists \\
\hline 3 & 885 & Educational scientists \\
\hline 3 & 886 & Psychologists \\
\hline 3 & 887 & Statisticians, market researchers and related professions \\
\hline 2 & 89 & Counselling professions \\
\hline 3 & 891 & Priests \\
\hline 3 & 894 & Monks, nuns - spiritual/pastoral care \\
\hline
\end{tabular}


Figure A.1: Shares of overall work links by occupation and industry

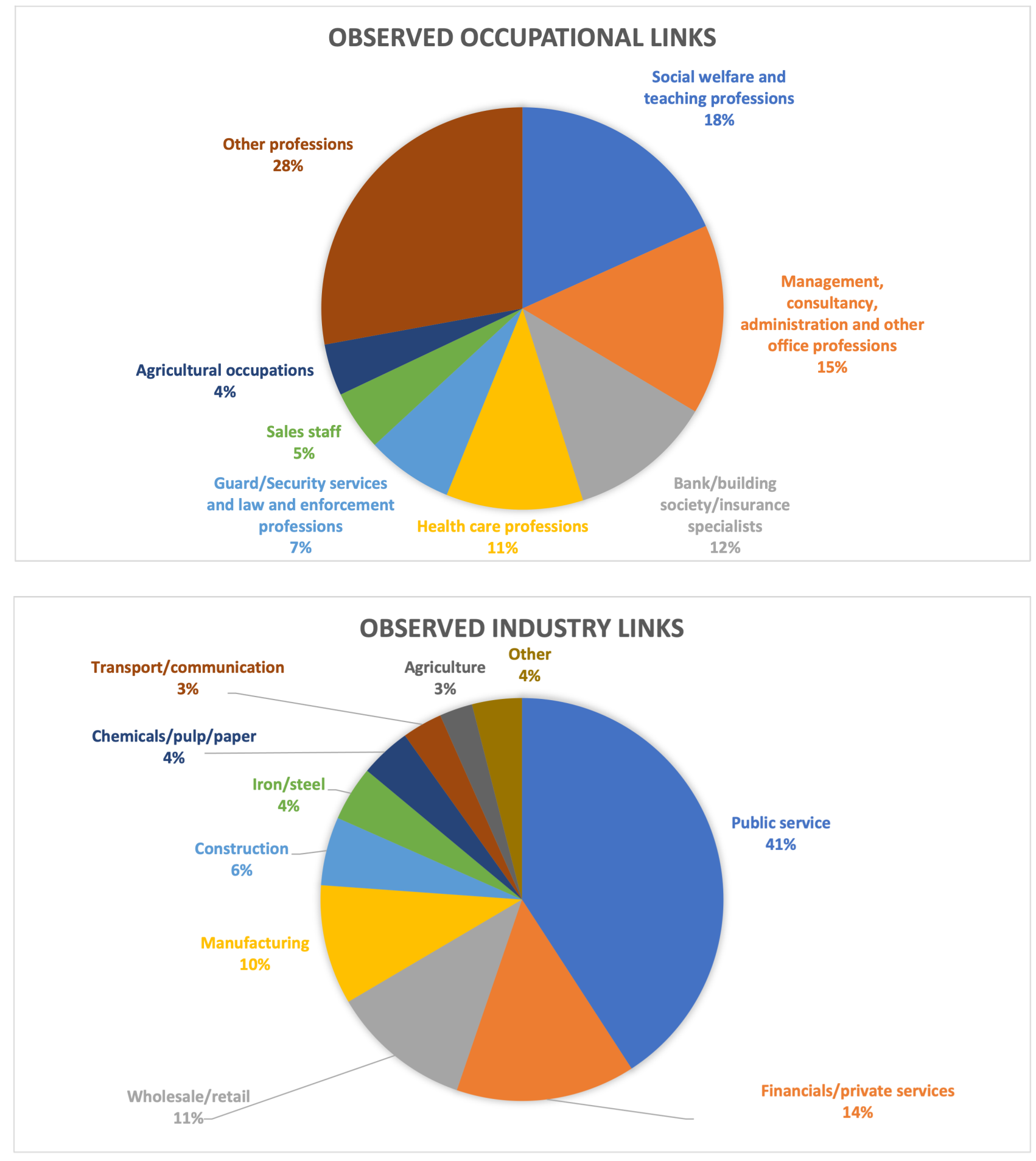

Source: SOEP 2019). Own calculations and illustration. 
Table A.2: Occupation-specific work link shares

\begin{tabular}{|c|c|c|c|c|c|}
\hline \multirow[t]{2}{*}{ Kldb92 - 2 digit level } & \multirow[t]{2}{*}{ Freq. } & \multicolumn{2}{|c|}{ Occupational WL } & \multicolumn{2}{|c|}{ Combined WL } \\
\hline & & Freq. & & Freq. & \\
\hline Management, consultancy, administration and other office professions & 26,409 & 1,176 & 4.45 & 758 & 2.87 \\
\hline Social welfare and teaching professions & 13,040 & 1,406 & 10.78 & 1,264 & 9.69 \\
\hline Sales staff & 10,058 & 372 & 3.7 & 328 & 3.26 \\
\hline Health care professions & 8,924 & 848 & 9.5 & 826 & 9.26 \\
\hline Other service professions & 7,586 & 366 & 6.32 & 322 & 4.47 \\
\hline Transport professions & 6,611 & 238 & 3.6 & 150 & 2.27 \\
\hline Metal and plant engineering and related professions & 6,189 & 90 & 1.45 & 70 & 1.13 \\
\hline Bank/building society/insurance specialists & 5,708 & 890 & 15.59 & 838 & 14.68 \\
\hline Guard/security services and law and enforcement professions & 4,926 & 538 & 10.92 & 496 & 10.07 \\
\hline Engineers, chemists, physicists, mathematicians & 4,900 & 304 & 6.2 & 194 & 3.96 \\
\hline Technicians and technical specialists & 4,449 & 98 & 2.2 & 76 & 1.71 \\
\hline Food manufacturing and processing professions & 2,377 & 150 & 6.31 & 124 & 5.22 \\
\hline Electrical professions & 2,361 & 54 & 2.29 & 52 & 2.2 \\
\hline Journalism, translation, librarian, artistic and related professions & 2,012 & 170 & 8.45 & 118 & 5.86 \\
\hline Agricultural occupations & 1,990 & 320 & 16.08 & 270 & 13.57 \\
\hline Structural and civil engineering professions & 1,699 & 12 & 0.71 & 8 & 0.47 \\
\hline Metal manufacturing and processing professions & 1,542 & 32 & 2.08 & 24 & 1.56 \\
\hline Goods inspectors, dispatch workers & 1,442 & 70 & 4.85 & 44 & 3.05 \\
\hline Installation and other metal professions & 1,323 & 138 & 10.43 & 122 & 9.22 \\
\hline Extension building professions and interior decorators, upholsterers & 1,208 & 6 & 0.5 & 6 & 0.5 \\
\hline Machine, plant operators and machine setters & 1,165 & 16 & 1.37 & 6 & 0.52 \\
\hline Chemistry and synthetic materials professions & 1,160 & 58 & 5 & 58 & 5 \\
\hline Arts and natural science professions & 1,072 & 86 & 5.69 & 58 & 5.41 \\
\hline Wood and synthetic materials processing professions & 1,036 & 60 & 5.79 & 48 & 4.63 \\
\hline Unskilled workers & 886 & 130 & 14.67 & 92 & 10.38 \\
\hline Paper manufacturing/processing and print (processing) professions & 743 & 22 & 2.96 & 22 & 2.96 \\
\hline Painters, varnishers and related professions & 716 & 14 & 1.96 & 14 & 1.96 \\
\hline Textil manufacturing and processing professions & 581 & 18 & 3.1 & 18 & 3.1 \\
\hline Ceramists and glass manufacturing/processing professions & 201 & 4 & 1.99 & 4 & 1.99 \\
\hline Leather manufacturing, leather/fur processing professions & 170 & 2 & 1.18 & 0 & 0 \\
\hline Wood processing, wood/woven goods manufacturing professions & 142 & 6 & 4.23 & 6 & 4.23 \\
\hline Mining occupations & 106 & 0 & 0 & 0 & 0 \\
\hline Stone processors and construction material manufacturers & 105 & 0 & 0 & 0 & 0 \\
\hline Total & 122,456 & 7,694 & 6.28 & 6,416 & 5.24 \\
\hline
\end{tabular}

Source: [SOEP $[2019)$. Own calculations.

Table A.3: Industry-specific work link shares

\begin{tabular}{llllll}
\hline Industries & Freq. & \multicolumn{2}{l}{ Industrial WL } & \multicolumn{2}{l}{ Combined WL } \\
& & Freq. & $\%$ & Freq. & $\%$ \\
\hline Agriculture & 1,962 & 612 & 31.19 & 254 & 12.95 \\
Mining, quarrying, energy & 1,758 & 130 & 7.39 & 6 & 0.34 \\
Manufacturing & 15,450 & 2,218 & 14.36 & 300 & 1.94 \\
Chemicals/pulp/paper & 6,312 & 944 & 14.96 & 180 & 2.85 \\
Construction & 8,411 & 1,268 & 15.08 & 118 & 1.4 \\
Iron/steel & 6,024 & 1,018 & 16.9 & 184 & 3.05 \\
Textile/apparel & 1,312 & 210 & 16.01 & 68 & 5.18 \\
Wholesale/retail & 14,698 & 2,602 & 17.7 & 432 & 2.94 \\
Transport/communication & 6,304 & 742 & 11.77 & 186 & 2.95 \\
Public service & 38,671 & 9,424 & 24.37 & 3,048 & 7.88 \\
Financial/private services & 16,288 & 3,324 & 20.41 & 1,428 & 8.77 \\
Not categorized & 5,266 & 584 & 11.09 & 212 & 4.03 \\
\hline Total & 122,456 & 23,076 & 18.84 & 6,416 & 5.24 \\
\hline Source: SOEP [2019). Own calculations. & & & &
\end{tabular}


Table A.4: Descriptive statistics outcome variables by work link

\begin{tabular}{|c|c|c|c|c|c|c|}
\hline & \multicolumn{3}{|c|}{ All } & \multirow{2}{*}{$\begin{array}{c}\text { No WL } \\
\text { mean }\end{array}$} & \multirow{2}{*}{$\begin{array}{l}\mathbf{W L} \\
\text { mean }\end{array}$} & \multirow{2}{*}{$\begin{array}{l}\text { t-test } \\
\text { p-value }\end{array}$} \\
\hline & $\mathrm{N}$ & mean & $\mathrm{SD}$ & & & \\
\hline Life satisfaction & 122,456 & 7.35 & 1.53 & 7.34 & 7.54 & 0.00 \\
\hline Work satisfaction & 122,456 & 7.12 & 1.93 & 7.11 & 7.25 & 0.00 \\
\hline Family satisfaction & 68,782 & 8.16 & 1.61 & 8.16 & 8.17 & 0.91 \\
\hline Leisure satisfaction & 111,288 & 6.55 & 2.16 & 6.55 & 6.41 & 0.00 \\
\hline Income satisfaction & 78,016 & 6.61 & 2.11 & 6.58 & 7.17 & 0.00 \\
\hline
\end{tabular}

Source: SOEP 2019]. Own calculations. 
Table A.5: Summary statistics by work link

\begin{tabular}{|c|c|c|c|c|}
\hline & $\begin{array}{l}\text { All } \\
\text { mean }\end{array}$ & $\begin{array}{l}\text { No WL } \\
\text { mean }\end{array}$ & $\begin{array}{l}\text { WL } \\
\text { mean }\end{array}$ & $\begin{array}{l}\text { t-test } \\
\text { p-value }\end{array}$ \\
\hline \multicolumn{5}{|l|}{ Individual characteristics } \\
\hline Female & 0.50 & 0.50 & 0.50 & 1.00 \\
\hline \multicolumn{5}{|l|}{ Age } \\
\hline 25-34 years & 0.18 & 0.18 & 0.20 & 0.00 \\
\hline $35-44$ years & 0.37 & 0.37 & 0.35 & 0.00 \\
\hline $45-54$ years & 0.33 & 0.33 & 0.30 & 0.00 \\
\hline 55-64 years & 0.12 & 0.11 & 0.15 & 0.00 \\
\hline Years of education & 12.57 & 12.51 & 13.65 & 0.00 \\
\hline Self-employed & 0.09 & 0.09 & 0.16 & 0.00 \\
\hline Tenure (in years) & 11.58 & 11.46 & 13.82 & 0.00 \\
\hline \multicolumn{5}{|l|}{ Firm size (number of employees) } \\
\hline small (under 20) & 0.29 & 0.30 & 0.26 & 0.00 \\
\hline medium $(20-199)$ & 0.26 & 0.27 & 0.21 & 0.00 \\
\hline large (200 and more) & 0.44 & 0.44 & 0.53 & 0.00 \\
\hline In trained occupation & 0.59 & 0.59 & 0.69 & 0.00 \\
\hline Fixed-term contract & 0.06 & 0.06 & 0.06 & 0.41 \\
\hline Full-time employed & 0.64 & 0.64 & 0.64 & 0.28 \\
\hline Net Labor income & 1644.91 & 1625.26 & 2000.17 & 0.00 \\
\hline Equivalent income & 2022.11 & 2000.73 & 2408.63 & 0.00 \\
\hline \multicolumn{5}{|l|}{ Occupational autonomy } \\
\hline Untrained & 0.14 & 0.14 & 0.11 & 0.00 \\
\hline Low level & 0.27 & 0.28 & 0.15 & 0.00 \\
\hline Executive level & 0.31 & 0.31 & 0.27 & 0.00 \\
\hline Middle level & 0.24 & 0.23 & 0.37 & 0.00 \\
\hline Upper level & 0.05 & 0.04 & 0.09 & 0.00 \\
\hline Working hours & 37.37 & 37.22 & 40.09 & 0.00 \\
\hline \multicolumn{5}{|l|}{ Household characteristics } \\
\hline Married & 0.88 & 0.88 & 0.83 & 0.00 \\
\hline Number of children in $\mathrm{HH}$ & 0.89 & 0.89 & 0.90 & 0.44 \\
\hline Partnership length & 7.75 & 7.81 & 6.68 & 0.00 \\
\hline Censored partnership length & 0.73 & 0.73 & 0.72 & 0.17 \\
\hline \multicolumn{5}{|l|}{ Partner characteristics } \\
\hline Years of education & 12.57 & 12.51 & 13.65 & 0.00 \\
\hline Tenure & 11.58 & 11.46 & 13.82 & 0.00 \\
\hline In trained occupation & 0.59 & 0.59 & 0.69 & 0.00 \\
\hline Fixed-term contract & 0.06 & 0.06 & 0.06 & 0.41 \\
\hline Full-time employed & 0.64 & 0.64 & 0.64 & 0.28 \\
\hline \multicolumn{5}{|l|}{ Regional characteristics } \\
\hline Schleswig-Holstein & 0.03 & 0.03 & 0.03 & 0.26 \\
\hline Hamburg & 0.01 & 0.01 & 0.01 & 0.87 \\
\hline Lower Saxony & 0.09 & 0.09 & 0.07 & 0.00 \\
\hline Bremen & 0.01 & 0.01 & 0.01 & 0.03 \\
\hline North Rhine-Westphalia & 0.20 & 0.20 & 0.20 & 0.32 \\
\hline Hesse & 0.08 & 0.08 & 0.07 & 0.00 \\
\hline Rhinel.-Palatinate & 0.05 & 0.05 & 0.04 & 0.26 \\
\hline Baden-Wuerttemberg & 0.13 & 0.13 & 0.13 & 0.06 \\
\hline Bavaria & 0.15 & 0.15 & 0.19 & 0.00 \\
\hline Saarland & 0.01 & 0.01 & 0.00 & 0.00 \\
\hline Berlin & 0.03 & 0.03 & 0.04 & 0.00 \\
\hline Brandenburg & 0.04 & 0.04 & 0.03 & 0.01 \\
\hline Mecklenburg-Western Pomerania & 0.02 & 0.02 & 0.03 & 0.01 \\
\hline Saxony & 0.07 & 0.07 & 0.05 & 0.00 \\
\hline Saxony-Anhalt & 0.04 & 0.04 & 0.03 & 0.01 \\
\hline Thuringia & 0.04 & 0.04 & 0.05 & 0.00 \\
\hline
\end{tabular}

Source: SOEP [2019]. Own calculations. 
Table A.6: Main estimation results

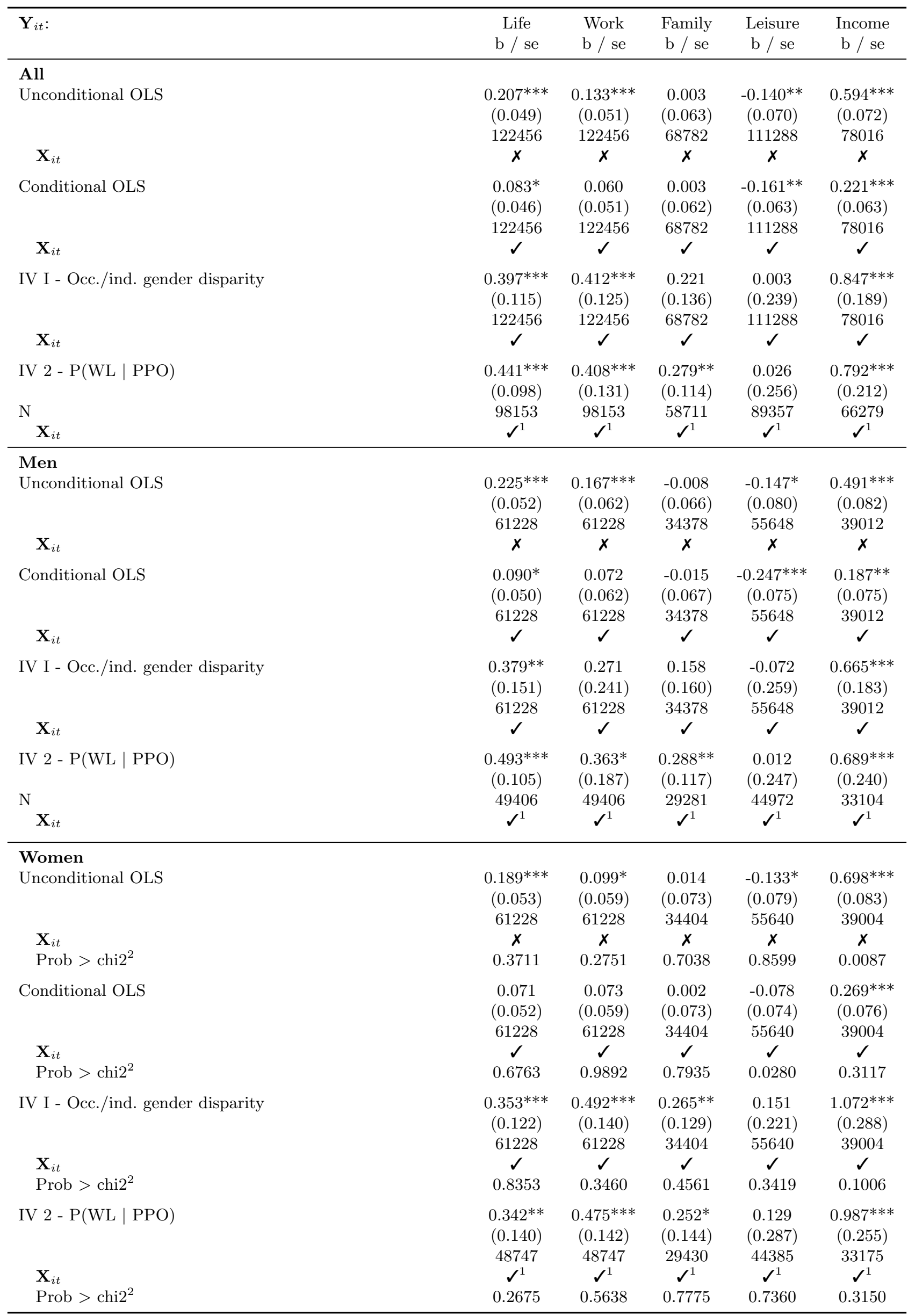

Source: SOEP (2019); Bundeagentur für Arbeit (2016a|b). Own calculations.

Note: Clustered standard errors in parentheses. ${ }^{*} p<0.1,{ }^{* *} p<0.05,{ }^{* * *} p<0.01 .{ }^{1}$ Specifications without federal state indicators due to non-convergence. ${ }^{2} \mathrm{P}$-values refer to the test for equality of the coefficients between the equations for men and women. 
Table A.7: Ancillary analysis - Endogenous variables

\begin{tabular}{|c|c|c|c|c|c|c|c|c|c|c|c|c|c|c|c|}
\hline \multirow[t]{2}{*}{$\mathbf{Y}_{i t}$} & \multicolumn{3}{|c|}{ Life } & \multicolumn{3}{|c|}{ Work } & \multicolumn{3}{|c|}{ Family } & \multicolumn{3}{|c|}{ Leisure } & \multicolumn{3}{|c|}{ Income } \\
\hline & OLS & IV1 & IV2 & OLS & IV1 & IV2 & OLS & IV1 & IV2 & OLS & IV1 & IV2 & OLS & IV1 & IV2 \\
\hline \multicolumn{16}{|c|}{ Occupational autonomy } \\
\hline WL & $\begin{array}{c}0.067 \\
(0.046)\end{array}$ & $\begin{array}{c}0.437^{* * *} \\
(0.105)\end{array}$ & $\begin{array}{c}0.427^{* * *} \\
(0.081)\end{array}$ & $\begin{array}{c}0.051 \\
(0.051)\end{array}$ & $\begin{array}{c}0.387^{* * *} \\
(0.110)\end{array}$ & $\begin{array}{c}0.306^{* *} \\
(0.144)\end{array}$ & $\begin{array}{c}0.001 \\
(0.063)\end{array}$ & $\begin{array}{l}0.213^{*} \\
(0.126)\end{array}$ & $\begin{array}{c}0.260^{* *} \\
(0.101)\end{array}$ & $\begin{array}{c}-0.181^{* * *} \\
(0.065)\end{array}$ & $\begin{array}{c}0.156 \\
(0.262)\end{array}$ & $\begin{array}{c}0.090 \\
(0.264)\end{array}$ & $\begin{array}{c}0.179^{* * *} \\
(0.063)\end{array}$ & $\begin{array}{c}0.896^{* * *} \\
(0.193)\end{array}$ & $\begin{array}{c}0.750^{* * *} \\
(0.159)\end{array}$ \\
\hline \multicolumn{16}{|c|}{ Occupational Autonomy (Ref.: Untrained) } \\
\hline Apprentice & $\begin{array}{c}0.004 \\
(0.091)\end{array}$ & $\begin{array}{c}0.005 \\
(0.100)\end{array}$ & $\begin{array}{c}0.044 \\
(0.097)\end{array}$ & $\begin{array}{c}0.568^{* * *} \\
(0.109)\end{array}$ & $\begin{array}{c}0.570 * * * \\
(0.124)\end{array}$ & $\begin{array}{c}0.604^{* * *} \\
(0.117)\end{array}$ & $\begin{array}{l}-0.133 \\
(0.142)\end{array}$ & $\begin{array}{l}-0.132 \\
(0.144)\end{array}$ & $\begin{array}{l}-0.022 \\
(0.130)\end{array}$ & $\begin{array}{c}-0.399^{* * * *} \\
(0.142)\end{array}$ & $\begin{array}{c}-0.398^{* * * *} \\
(0.140)\end{array}$ & $\begin{array}{l}-0.275^{*} \\
(0.160)\end{array}$ & $\begin{array}{c}-1.277^{* * *} \\
(0.163)\end{array}$ & $\begin{array}{c}-1.273^{* * *} \\
(0.199)\end{array}$ & $\begin{array}{c}-1.137^{* * *} \\
(0.179)\end{array}$ \\
\hline Low & $\begin{array}{c}0.024 \\
(0.032)\end{array}$ & $\begin{array}{c}0.025 \\
(0.030)\end{array}$ & $\begin{array}{l}0.066^{*} \\
(0.037)\end{array}$ & $\begin{array}{c}0.266^{* * *} * \\
(0.038)\end{array}$ & $\begin{array}{c}0.267^{* * *} \\
(0.035)\end{array}$ & $\begin{array}{c}0.307^{* * *} \\
(0.044)\end{array}$ & $\begin{array}{l}-0.035 \\
(0.040)\end{array}$ & $\begin{array}{l}-0.033 \\
(0.039)\end{array}$ & $\begin{array}{c}0.004 \\
(0.046)\end{array}$ & $\begin{array}{c}-0.115^{* * * *} \\
(0.044)\end{array}$ & $\begin{array}{c}-0.115^{* *} \\
(0.056)\end{array}$ & $\begin{array}{l}-0.048 \\
(0.048)\end{array}$ & $\begin{array}{c}0.272^{* * *} \\
(0.051)\end{array}$ & $\begin{array}{c}0.276^{* * *} \\
(0.047)\end{array}$ & $\begin{array}{c}0.273^{* * * *} \\
(0.056)\end{array}$ \\
\hline Middle & $\begin{array}{c}0.226^{* * *} * \\
(0.041)\end{array}$ & $\begin{array}{c}0.226^{* * *} \\
(0.040)\end{array}$ & $\begin{array}{c}0.266^{* * *} \\
(0.046)\end{array}$ & $\begin{array}{c}0.591^{* * *} \\
(0.048)\end{array}$ & $\begin{array}{c}0.591^{* * *} \\
(0.046)\end{array}$ & $\begin{array}{c}0.639^{* * *} \\
(0.054)\end{array}$ & $\begin{array}{l}-0.081 \\
(0.052)\end{array}$ & $\begin{array}{c}-0.080^{*} \\
(0.047)\end{array}$ & $\begin{array}{l}-0.040 \\
(0.057)\end{array}$ & $\begin{array}{c}-0.568^{* * * *} \\
(0.060)\end{array}$ & $\begin{array}{c}-0.568^{* * *} \\
(0.089)\end{array}$ & $\begin{array}{c}-0.402^{* * *} \\
(0.062)\end{array}$ & $\begin{array}{c}1.085 * * * \\
(0.065)\end{array}$ & $\begin{array}{c}1.087^{* * *} \\
(0.062)\end{array}$ & $\begin{array}{c}1.086^{* * *} * \\
(0.071)\end{array}$ \\
\hline Manag. & $\begin{array}{c}0.496^{* * *} \\
(0.054)\end{array}$ & $\begin{array}{c}0.496^{* * *} \\
(0.055)\end{array}$ & $\begin{array}{c}0.509 * * * \\
(0.060)\end{array}$ & $\begin{array}{c}1.037^{* * *} \\
(0.065)\end{array}$ & $\begin{array}{c}1.037^{* * *} \\
(0.069)\end{array}$ & $\begin{array}{c}1.055^{* * *} \\
(0.073)\end{array}$ & $\begin{array}{c}0.022 \\
(0.069)\end{array}$ & $\begin{array}{c}0.021 \\
(0.060)\end{array}$ & $\begin{array}{c}0.054 \\
(0.075)\end{array}$ & $\begin{array}{c}-0.588^{* * * *} \\
(0.082)\end{array}$ & $\begin{array}{c}-0.589^{* * * *} \\
(0.100)\end{array}$ & $\begin{array}{c}-0.432^{* * * *} \\
(0.088)\end{array}$ & $\begin{array}{c}1.819^{* * *} \\
(0.082)\end{array}$ & $\begin{array}{c}1.817^{* * *} \\
(0.086)\end{array}$ & $\begin{array}{c}1.801^{* * *} \\
(0.088)\end{array}$ \\
\hline $\mathrm{N}$ & 122456 & 122456 & 98153 & 122456 & 122456 & 98153 & 68782 & 68782 & 58711 & 111288 & 111288 & 89357 & 78016 & 78016 & 66279 \\
\hline \multicolumn{16}{|l|}{ Labor income } \\
\hline WL & $\begin{array}{c}0.058 \\
(0.045)\end{array}$ & $\begin{array}{c}0.438^{* * *} \\
(0.105)\end{array}$ & $\begin{array}{c}0.416^{* * *} \\
(0.088)\end{array}$ & $\begin{array}{c}0.029 \\
(0.050)\end{array}$ & $\begin{array}{c}0.371^{* * *} \\
(0.111)\end{array}$ & $\begin{array}{c}0.317^{* *} \\
(0.144)\end{array}$ & $\begin{array}{c}0.001 \\
(0.063)\end{array}$ & $\begin{array}{l}0.214^{*} \\
(0.129)\end{array}$ & $\begin{array}{c}0.253^{* *} \\
(0.111)\end{array}$ & $\begin{array}{c}-0.172^{* * *} \\
(0.065)\end{array}$ & $\begin{array}{c}0.139 \\
(0.247)\end{array}$ & $\begin{array}{c}0.024 \\
(0.312)\end{array}$ & $\begin{array}{c}0.114^{* *} \\
(0.057)\end{array}$ & $\begin{array}{c}1.025^{* * *} \\
(0.218)\end{array}$ & $\begin{array}{c}1.024^{* * *} \\
(0.172)\end{array}$ \\
\hline $\log (\mathrm{LII})$ & $\begin{array}{c}0.228^{* * *} \\
(0.016)\end{array}$ & $\begin{array}{c}0.228^{* * *} \\
(0.017)\end{array}$ & $\begin{array}{c}0.230^{* * *} \\
(0.017)\end{array}$ & $\begin{array}{c}0.391^{* * *} \\
(0.020)\end{array}$ & $\begin{array}{c}0.390^{* * *} \\
(0.021)\end{array}$ & $\begin{array}{c}0.401^{* * *} \\
(0.022)\end{array}$ & $\begin{array}{l}-0.008 \\
(0.020)\end{array}$ & $\begin{array}{l}-0.009 \\
(0.018)\end{array}$ & $\begin{array}{l}-0.007 \\
(0.021)\end{array}$ & $\begin{array}{c}-0.389^{* * *} \\
(0.027)\end{array}$ & $\begin{array}{c}-0.389^{* * *} \\
(0.029)\end{array}$ & $-0.211^{* * *}$ & $1.202^{* * *}$ & $1.203^{* * *}$ & $1.221^{* * *}$ \\
\hline \multicolumn{16}{|c|}{ Net equivalent $\mathrm{HH}$ income } \\
\hline WL & $\begin{array}{c}0.050 \\
(0.044)\end{array}$ & $\begin{array}{c}0.417^{* * *} \\
(0.102)\end{array}$ & $\begin{array}{c}0.405^{* * *} \\
(0.085)\end{array}$ & $\begin{array}{c}0.044 \\
(0.049)\end{array}$ & $\begin{array}{c}0.383^{* * *} \\
(0.112)\end{array}$ & $\begin{array}{c}0.331^{* *} \\
(0.143)\end{array}$ & $\begin{array}{l}-0.009 \\
(0.063)\end{array}$ & $\begin{array}{c}0.198 \\
(0.135)\end{array}$ & $\begin{array}{c}0.242^{* *} \\
(0.110)\end{array}$ & $\begin{array}{c}-0.216^{* * *} \\
(0.065)\end{array}$ & $\begin{array}{c}0.055 \\
(0.286)\end{array}$ & $\begin{array}{l}-0.006 \\
(0.320)\end{array}$ & $\begin{array}{c}0.158^{* * *} \\
(0.057)\end{array}$ & $\begin{array}{c}0.932^{* * *} \\
(0.197)\end{array}$ & $\begin{array}{c}0.923^{* * *} \\
(0.161)\end{array}$ \\
\hline $\log ($ HHEI $)$ & $0.629^{* * *}$ & $0.629^{* * *}$ & $0.623^{* * *}$ & $0.525^{* * *}$ & $0.524^{* * *}$ & $0.533^{* * *}$ & $0.181^{* * *}$ & $0.180^{* * *}$ & $0.179^{* * *}$ & 0.063 & $0.063^{*}$ & $0.178^{* * *}$ & $1.563^{* * *}$ & $1.562^{* * *}$ & $1.579^{* * *}$ \\
\hline & $(0.029)$ & $(0.020)$ & $(0.032)$ & $(0.032)$ & $(0.027)$ & $(0.035)$ & $(0.039)$ & $(0.029)$ & $(0.042)$ & $(0.046)$ & $(0.038)$ & $(0.046)$ & $(0.042)$ & $(0.035)$ & $(0.044)$ \\
\hline $\mathrm{N}$ & 122276 & 122276 & 98020 & 122276 & 122276 & 98020 & 68782 & 68782 & 58711 & 111128 & 111128 & 89234 & 78016 & 78016 & 66279 \\
\hline \multicolumn{16}{|c|}{ Weekly working hours } \\
\hline WL & $\begin{array}{c}0.103^{* *} \\
(0.046)\end{array}$ & $\begin{array}{c}0.490^{* * *} \\
(0.095)\end{array}$ & $\begin{array}{c}0.448^{* * *} \\
(0.082)\end{array}$ & $\begin{array}{c}0.076 \\
(0.051)\end{array}$ & $\begin{array}{c}0.429^{* * *} \\
(0.109)\end{array}$ & $\begin{array}{c}0.304^{* *} \\
(0.154)\end{array}$ & $\begin{array}{c}0.003 \\
(0.063)\end{array}$ & $\begin{array}{c}0.196 \\
(0.132)\end{array}$ & $\begin{array}{l}0.251^{* *} \\
(0.102)\end{array}$ & $\begin{array}{l}-0.070 \\
(0.060)\end{array}$ & $\begin{array}{c}0.158 \\
(0.248)\end{array}$ & $\begin{array}{l}-0.001 \\
(2.245)\end{array}$ & $\begin{array}{c}0.213^{* * *} \\
(0.065)\end{array}$ & $\begin{array}{c}1.025^{* * *} \\
(0.178)\end{array}$ & $\begin{array}{c}0.809^{* * *} \\
(0.156)\end{array}$ \\
\hline Hours & $-0.006^{* * *}$ & $-0.006^{* * *}$ & $-0.006^{* * *}$ & 0.002 & 0.002 & $0.002^{* *}$ & $-0.010^{* * *}$ & $-0.010^{* * *}$ & $-0.010^{* * *}$ & $-0.054^{* * *}$ & $-0.054^{* * *}$ & $-0.051^{* * *}$ & $0.010^{* * *}$ & $0.010^{* * *}$ & $0.010^{* * *}$ \\
\hline $\mathrm{N}$ & $\begin{array}{l}(0.001) \\
119582\end{array}$ & $\begin{array}{l}(0.001) \\
119582\end{array}$ & $\begin{array}{l}(0.001) \\
96028\end{array}$ & $\begin{array}{l}(0.001) \\
119582\end{array}$ & $\begin{array}{l}(0.001) \\
119582\end{array}$ & $\begin{array}{c}(0.001) \\
96028\end{array}$ & $\begin{array}{l}(0.001) \\
67705\end{array}$ & $\begin{array}{l}(0.001) \\
67705\end{array}$ & $\begin{array}{l}(0.001) \\
57787\end{array}$ & $\begin{array}{l}(0.001) \\
108660\end{array}$ & $\begin{array}{l}(0.001) \\
108660\end{array}$ & $\begin{array}{l}(0.002) \\
87404\end{array}$ & $\begin{array}{c}(0.002) \\
76734\end{array}$ & $\begin{array}{c}(0.002) \\
76734\end{array}$ & $\begin{array}{c}(0.002) \\
65193\end{array}$ \\
\hline \multicolumn{16}{|c|}{ Subjective job security } \\
\hline & $\begin{array}{c}0.073 \\
(0.045)\end{array}$ & $\begin{array}{c}0.407^{* * *} \\
(0.100)\end{array}$ & $\begin{array}{c}0.427^{* * *} \\
(0.081)\end{array}$ & $\begin{array}{c}0.053 \\
(0.049)\end{array}$ & $\begin{array}{c}0.265^{* *} \\
(0.128)\end{array}$ & $\begin{array}{c}0.252 \\
(0.177)\end{array}$ & $\begin{array}{l}-0.003 \\
(0.063)\end{array}$ & $\begin{array}{l}0.216^{*} \\
(0.118)\end{array}$ & $\begin{array}{c}0.245^{* *} \\
(0.102)\end{array}$ & $\begin{array}{c}-0.215^{* * *} \\
(0.065)\end{array}$ & $\begin{array}{l}-0.005 \\
(0.299)\end{array}$ & $\begin{array}{c}0.026 \\
(0.279)\end{array}$ & $\begin{array}{c}0.217^{* * *} \\
(0.062)\end{array}$ & $\begin{array}{c}0.770^{* * *} \\
(0.151)\end{array}$ & $\begin{array}{c}0.760^{* * *} \\
(0.159)\end{array}$ \\
\hline \multicolumn{16}{|c|}{ Job loss worries (Ref.: Very worried) } \\
\hline A little worried & $\begin{array}{c}0.563^{* * *} \\
(0.026)\end{array}$ & $\begin{array}{c}0.563^{* * *} \\
(0.020)\end{array}$ & $\begin{array}{c}0.573^{* * *} \\
(0.029)\end{array}$ & $\begin{array}{c}0.852^{* * *} \\
(0.032)\end{array}$ & $\begin{array}{c}0.852^{* * *} \\
(0.029)\end{array}$ & $\begin{array}{c}0.884^{* * *} \\
(0.037)\end{array}$ & $\begin{array}{c}0.139^{* * *} \\
(0.036)\end{array}$ & $\begin{array}{c}0.139 * * * \\
(0.031)\end{array}$ & $\begin{array}{c}0.140^{* * *} \\
(0.039)\end{array}$ & $\begin{array}{c}0.332^{* * *} \\
(0.036)\end{array}$ & $\begin{array}{c}0.332^{* * *} \\
(0.029)\end{array}$ & $\begin{array}{c}0.357^{* * *} \\
(0.041)\end{array}$ & $\begin{array}{c}0.765^{* * *} \\
(0.041)\end{array}$ & $\begin{array}{c}0.765^{* * *} \\
(0.033)\end{array}$ & $\begin{array}{c}0.796^{* * *} \\
(0.044)\end{array}$ \\
\hline $\mathbf{X}_{i t}$ & $\checkmark$ & $\checkmark$ & $\checkmark$ & $\checkmark$ & $\checkmark$ & $\checkmark$ & $\checkmark$ & $\checkmark$ & $\checkmark$ & $\checkmark$ & $\checkmark$ & $\mathfrak{J}^{1}$ & $\checkmark$ & $\checkmark$ & $\checkmark$ \\
\hline
\end{tabular}

Source: SOEP $[2019) ;$; Bundeagentur für Arbeit
Note: Clustered standard errors in parentheses. ${ }^{*} p<0.1,{ }^{* *} p<0.05,{ }^{* * *} p<0.01$. To circumvent non-convergence, specifications in this table do

Note: Clustered standard errors in parentheses. $p<0.1,{ }^{* *} p<0.05,{ }^{* * *} p<0.01$. To circumvent non-convergence, specifications in this ta
not include federal state and self-employment indicators. ${ }^{1}$ Estimation additionally estimated without occupation FE due to non-convergence. 
Table A.8: Heterogeneity analysis

\begin{tabular}{|c|c|c|c|c|c|}
\hline $\mathbf{Y}_{i t}$ & Life & Work & Family & Leisure & Income \\
\hline \multicolumn{6}{|l|}{ 1) Education } \\
\hline WL & $\begin{array}{c}0.016 \\
(0.059)\end{array}$ & $\begin{array}{l}-0.015 \\
(0.065)\end{array}$ & $\begin{array}{l}-0.123 \\
(0.087)\end{array}$ & $\begin{array}{c}-0.204^{* *} \\
(0.081)\end{array}$ & $\begin{array}{c}0.094 \\
(0.084)\end{array}$ \\
\hline College & $\begin{array}{l}0.064^{*} \\
(0.036)\end{array}$ & $\begin{array}{l}-0.037 \\
(0.042)\end{array}$ & $\begin{array}{c}0.071 \\
(0.045)\end{array}$ & $\begin{array}{c}-0.217^{* * *} \\
(0.052)\end{array}$ & $\begin{array}{l}0.096^{*} \\
(0.056)\end{array}$ \\
\hline $\mathrm{WL} \times$ College & $\begin{array}{l}0.152^{*} \\
(0.087)\end{array}$ & $\begin{array}{l}0.179^{*} \\
(0.097)\end{array}$ & $\begin{array}{c}0.238^{* *} \\
(0.117)\end{array}$ & $\begin{array}{c}0.116 \\
(0.123)\end{array}$ & $\begin{array}{c}0.243^{* *} \\
(0.118)\end{array}$ \\
\hline \multicolumn{6}{|l|}{ 2) High income - Power couples } \\
\hline $\mathrm{WL}$ & $\begin{array}{c}0.024 \\
(0.063)\end{array}$ & $\begin{array}{l}-0.028 \\
(0.068)\end{array}$ & $\begin{array}{l}-0.115 \\
(0.097)\end{array}$ & $\begin{array}{c}-0.236^{* * *} \\
(0.086)\end{array}$ & $\begin{array}{c}0.088 \\
(0.101)\end{array}$ \\
\hline One high earner - Self & $\begin{array}{c}0.248^{* * *} \\
(0.026)\end{array}$ & $\begin{array}{c}0.321^{* * *} \\
(0.030)\end{array}$ & $\begin{array}{l}-0.025 \\
(0.033)\end{array}$ & $\begin{array}{c}-0.197^{* * *} \\
(0.038)\end{array}$ & $\begin{array}{c}1.171^{* * *} \\
(0.038)\end{array}$ \\
\hline One high earner - Partner & $\begin{array}{c}0.218^{* * *} \\
(0.026)\end{array}$ & $\begin{array}{c}0.080^{* * *} \\
(0.030)\end{array}$ & $\begin{array}{l}-0.005 \\
(0.033)\end{array}$ & $\begin{array}{c}0.107^{* * *} \\
(0.037)\end{array}$ & $\begin{array}{c}0.166^{* * *} \\
(0.040)\end{array}$ \\
\hline Two high earners & $\begin{array}{c}0.297^{* * *} \\
(0.046)\end{array}$ & $\begin{array}{c}0.362^{* * *} \\
(0.053)\end{array}$ & $\begin{array}{l}-0.016 \\
(0.059)\end{array}$ & $\begin{array}{c}-0.137^{* *} \\
(0.069)\end{array}$ & $\begin{array}{c}1.239 * * * \\
(0.059)\end{array}$ \\
\hline WL $\times$ One high earner - Self & $\begin{array}{c}0.080 \\
(0.087)\end{array}$ & $\begin{array}{c}0.112 \\
(0.105)\end{array}$ & $\begin{array}{c}0.100 \\
(0.127)\end{array}$ & $\begin{array}{c}0.116 \\
(0.128)\end{array}$ & $\begin{array}{l}-0.003 \\
(0.133)\end{array}$ \\
\hline WL $\times$ One high earner - Partner & $\begin{array}{l}-0.008 \\
(0.085)\end{array}$ & $\begin{array}{l}0.106 \\
(0.107)\end{array}$ & $\begin{array}{l}0.120 \\
(0.121)\end{array}$ & $\begin{array}{c}0.164 \\
(0.123)\end{array}$ & $\begin{array}{l}0.194 \\
(0.146)\end{array}$ \\
\hline WL $\times$ Two high earners & $\begin{array}{c}0.235^{* *} \\
(0.115)\end{array}$ & $\begin{array}{l}0.219^{*} \\
(0.131)\end{array}$ & $\begin{array}{l}0.279^{*} \\
(0.151)\end{array}$ & $\begin{array}{l}0.203 \\
(0.162)\end{array}$ & $\begin{array}{l}0.141 \\
(0.141)\end{array}$ \\
\hline \multicolumn{6}{|l|}{ 3) Labor force status } \\
\hline WL & $\begin{array}{c}0.019 \\
(0.113)\end{array}$ & $\begin{array}{c}0.013 \\
(0.118)\end{array}$ & $\begin{array}{c}0.012 \\
(0.161)\end{array}$ & $\begin{array}{c}-0.593^{* * *} \\
(0.173)\end{array}$ & $\begin{array}{c}0.077 \\
(0.176)\end{array}$ \\
\hline Employed & $\begin{array}{l}0.040 \\
(0.036)\end{array}$ & $\begin{array}{c}-0.273^{* * *} \\
(0.044)\end{array}$ & $\begin{array}{c}0.166^{* * *} \\
(0.047)\end{array}$ & $\begin{array}{c}1.055^{* * *} \\
(0.061)\end{array}$ & $\begin{array}{c}-0.346^{* * *} \\
(0.065)\end{array}$ \\
\hline $\mathrm{WL} \times$ Employed & $\begin{array}{l}0.075 \\
(0.119)\end{array}$ & $\begin{array}{c}0.055 \\
(0.127)\end{array}$ & $\begin{array}{l}-0.010 \\
(0.169)\end{array}$ & $\begin{array}{c}0.514^{* * *} \\
(0.182)\end{array}$ & $\begin{array}{c}0.168 \\
(0.182)\end{array}$ \\
\hline \multicolumn{6}{|l|}{ 4) Industry / sector } \\
\hline WL & $\begin{array}{c}0.146^{* *} \\
(0.058)\end{array}$ & $\begin{array}{c}0.066 \\
(0.063)\end{array}$ & $\begin{array}{c}0.050 \\
(0.072)\end{array}$ & $\begin{array}{l}-0.128 \\
(0.079)\end{array}$ & $\begin{array}{c}0.281^{* * *} \\
(0.069)\end{array}$ \\
\hline \multicolumn{6}{|l|}{ Industry / sector (Ref.: Services) } \\
\hline Agriculture & $\begin{array}{c}0.041 \\
(0.090)\end{array}$ & $\begin{array}{c}0.215^{* *} \\
(0.104)\end{array}$ & $\begin{array}{l}0.145 \\
(0.101)\end{array}$ & $\begin{array}{l}-0.032 \\
(0.136)\end{array}$ & $\begin{array}{l}-0.223 \\
(0.161)\end{array}$ \\
\hline Secondary sector & $\begin{array}{l}0.213^{* *} \\
(0.105)\end{array}$ & $\begin{array}{c}0.306^{* * *} \\
(0.106)\end{array}$ & $\begin{array}{l}-0.004 \\
(0.163)\end{array}$ & $\begin{array}{l}0.289^{* *} \\
(0.141)\end{array}$ & $\begin{array}{l}0.240 \\
(0.172)\end{array}$ \\
\hline Wholesale, retail, transport, communication & $\begin{array}{l}-0.072 \\
(0.048)\end{array}$ & $\begin{array}{l}-0.080 \\
(0.061)\end{array}$ & $\begin{array}{l}0.025 \\
(0.063)\end{array}$ & $\begin{array}{l}-0.006 \\
(0.072)\end{array}$ & $\begin{array}{l}0.124^{*} \\
(0.073)\end{array}$ \\
\hline Other & $\begin{array}{c}0.069 \\
(0.050)\end{array}$ & $\begin{array}{c}0.272^{* * *} \\
(0.059)\end{array}$ & $\begin{array}{l}0.105^{*} \\
(0.063)\end{array}$ & $\begin{array}{c}0.272^{* * *} \\
(0.073)\end{array}$ & $\begin{array}{c}0.069 \\
(0.084)\end{array}$ \\
\hline $\mathrm{WL} \times$ Agriculture & $\begin{array}{c}-0.452^{* *} \\
(0.218)\end{array}$ & $\begin{array}{c}-0.348^{*} \\
(0.194)\end{array}$ & $\begin{array}{c}-0.909 * * * \\
(0.349)\end{array}$ & $\begin{array}{c}-0.839^{* *} \\
(0.359)\end{array}$ & $\begin{array}{c}-1.026^{* *} \\
(0.404)\end{array}$ \\
\hline $\mathrm{WL} \times$ Secondary sector & $\begin{array}{l}-0.120 \\
(0.112)\end{array}$ & $\begin{array}{l}0.085 \\
(0.135)\end{array}$ & $\begin{array}{c}0.128 \\
(0.159)\end{array}$ & $\begin{array}{c}0.324^{* *} \\
(0.157)\end{array}$ & $\begin{array}{c}0.051 \\
(0.228)\end{array}$ \\
\hline WL $\times$ Wholesale, retail, transport, communication & $\begin{array}{c}-0.245^{*} \\
(0.130)\end{array}$ & $\begin{array}{l}-0.016 \\
(0.165)\end{array}$ & $\begin{array}{l}-0.251 \\
(0.244)\end{array}$ & $\begin{array}{c}-0.371^{* *} \\
(0.180)\end{array}$ & $\begin{array}{l}-0.325 \\
(0.248)\end{array}$ \\
\hline WL $\times$ Other & $\begin{array}{l}-0.144 \\
(0.156)\end{array}$ & $\begin{array}{l}-0.093 \\
(0.179)\end{array}$ & $\begin{array}{l}-0.409 \\
(0.263)\end{array}$ & $\begin{array}{l}-0.229 \\
(0.289)\end{array}$ & $\begin{array}{l}-0.275 \\
(0.349)\end{array}$ \\
\hline \multicolumn{6}{|l|}{ 5) Region } \\
\hline WL & $\begin{array}{c}0.063 \\
(0.052)\end{array}$ & $\begin{array}{c}0.081 \\
(0.055)\end{array}$ & $\begin{array}{c}0.024 \\
(0.071)\end{array}$ & $\begin{array}{c}-0.159^{* *} \\
(0.072)\end{array}$ & $\begin{array}{c}0.185^{* * *} \\
(0.070)\end{array}$ \\
\hline East & $\begin{array}{c}-0.679^{* * *} \\
(0.084)\end{array}$ & $\begin{array}{c}-0.532^{* * *} \\
(0.102)\end{array}$ & $\begin{array}{c}-0.335^{* * *} \\
(0.098)\end{array}$ & $\begin{array}{c}-0.812^{* * *} \\
(0.130)\end{array}$ & $\begin{array}{c}-0.691^{* * *} \\
(0.131)\end{array}$ \\
\hline $\mathrm{WL} \times$ East & $\begin{array}{c}0.096 \\
(0.106)\end{array}$ & $\begin{array}{l}-0.105 \\
(0.131)\end{array}$ & $\begin{array}{l}-0.087 \\
(0.145)\end{array}$ & $\begin{array}{l}-0.007 \\
(0.154)\end{array}$ & $\begin{array}{c}0.162 \\
(0.154)\end{array}$ \\
\hline
\end{tabular}

6) Time Period

WL

$0.052 \quad-0.025$

$-0.416^{* * *}$ 
Table A.8: Heterogeneity Analysis (ctd.)

\begin{tabular}{|c|c|c|c|c|c|}
\hline $\mathbf{Y}_{i t}:$ & Life & Work & Family & Leisure & Income \\
\hline & $(0.088)$ & $(0.095)$ & & $(0.143)$ & \\
\hline \multirow[t]{2}{*}{ Post 2000} & $0.456^{* * *}$ & $0.116^{* *}$ & & $0.429^{* * *}$ & \\
\hline & $(0.047)$ & $(0.054)$ & & $(0.064)$ & \\
\hline \multirow[t]{2}{*}{ WL $\times$ Post 2000} & 0.040 & 0.111 & & $0.329 * *$ & \\
\hline & $(0.097)$ & $(0.105)$ & & $(0.155)$ & \\
\hline \multicolumn{6}{|l|}{ 7) Relative income } \\
\hline \multirow[t]{2}{*}{ WL } & 0.005 & 0.071 & -0.046 & -0.128 & $0.323^{* * *}$ \\
\hline & $(0.059)$ & $(0.076)$ & $(0.077)$ & $(0.084)$ & $(0.084)$ \\
\hline \multicolumn{6}{|c|}{ Relative Income (Ref.: Income < Partner income) } \\
\hline Inc. = Partner inc. & $\begin{array}{l}-0.030 \\
(0.025)\end{array}$ & $\begin{array}{c}0.164 * * * \\
(0.030)\end{array}$ & $\begin{array}{c}0.007 \\
(0.034)\end{array}$ & $\begin{array}{c}-0.133^{* * *} \\
(0.036)\end{array}$ & $\begin{array}{c}0.692^{* * *} \\
(0.039)\end{array}$ \\
\hline Inc. > Partner inc. & $\begin{array}{c}0.092^{* * *} \\
(0.020)\end{array}$ & $\begin{array}{c}0.408^{* * *} \\
(0.031)\end{array}$ & $\begin{array}{l}-0.030 \\
(0.026)\end{array}$ & $\begin{array}{c}-0.209^{* * *} \\
(0.034)\end{array}$ & $\begin{array}{c}1.343^{* * *} \\
(0.039)\end{array}$ \\
\hline $\mathrm{WL} \times$ Inc. $=$ Partner inc. & $\begin{array}{c}0.130 \\
(0.079)\end{array}$ & $\begin{array}{l}-0.045 \\
(0.093)\end{array}$ & $\begin{array}{c}0.057 \\
(0.116)\end{array}$ & $\begin{array}{l}-0.026 \\
(0.112)\end{array}$ & $\begin{array}{l}-0.179 \\
(0.110)\end{array}$ \\
\hline WL $\times$ Inc. $>$ Partner inc. & $\begin{array}{c}0.029 \\
(0.047)\end{array}$ & $\begin{array}{l}-0.003 \\
(0.082)\end{array}$ & $\begin{array}{c}0.053 \\
(0.062)\end{array}$ & $\begin{array}{l}-0.082 \\
(0.092)\end{array}$ & $\begin{array}{c}-0.300^{* * *} \\
(0.090)\end{array}$ \\
\hline $\log (\mathrm{NHHI})$ & $\begin{array}{c}0.581^{* * *} \\
(0.029)\end{array}$ & $\begin{array}{c}0.504^{* * *} \\
(0.032)\end{array}$ & $\begin{array}{c}0.197^{* * *} \\
(0.040)\end{array}$ & $\begin{array}{c}0.070 \\
(0.044)\end{array}$ & $\begin{array}{c}1.589^{* * *} \\
(0.042)\end{array}$ \\
\hline \multicolumn{6}{|l|}{ 8) Risk aversion } \\
\hline WL & $\begin{array}{c}0.096 \\
(0.061)\end{array}$ & $\begin{array}{c}0.007 \\
(0.070)\end{array}$ & $\begin{array}{l}-0.008 \\
(0.083)\end{array}$ & $\begin{array}{r}-0.157^{*} \\
(0.083)\end{array}$ & $\begin{array}{c}0.232^{* * *} \\
(0.085)\end{array}$ \\
\hline Risk seeker & $\begin{array}{c}0.153^{* * *} \\
(0.021)\end{array}$ & $\begin{array}{c}0.149^{* * *} \\
(0.024)\end{array}$ & $\begin{array}{c}0.049^{* *} \\
(0.025)\end{array}$ & $\begin{array}{c}0.079^{* * *} \\
(0.030)\end{array}$ & $\begin{array}{c}0.193^{* * *} \\
(0.031)\end{array}$ \\
\hline WL $\times$ Risk seeker & $\begin{array}{l}-0.022 \\
(0.074)\end{array}$ & $\begin{array}{l}0.096 \\
(0.084)\end{array}$ & $\begin{array}{l}0.021 \\
(0.100)\end{array}$ & $\begin{array}{l}-0.005 \\
(0.108)\end{array}$ & $\begin{array}{l}-0.020 \\
(0.107)\end{array}$ \\
\hline \multicolumn{6}{|l|}{ 9) Age } \\
\hline $\mathrm{WL}$ & $\begin{array}{c}0.051 \\
(0.064)\end{array}$ & $\begin{array}{l}-0.112 \\
(0.083)\end{array}$ & $\begin{array}{c}-0.336^{* * *} \\
(0.127)\end{array}$ & $\begin{array}{l}-0.199^{*} \\
(0.114)\end{array}$ & $\begin{array}{c}0.188 \\
(0.141)\end{array}$ \\
\hline \multicolumn{6}{|l|}{ Age group (Ref.: 25-34 years) } \\
\hline $35-44$ years & $\begin{array}{c}-0.128^{* * *} \\
(0.021)\end{array}$ & $\begin{array}{l}-0.020 \\
(0.025)\end{array}$ & $\begin{array}{c}-0.215^{* * *} \\
(0.031)\end{array}$ & $\begin{array}{l}-0.051 \\
(0.032)\end{array}$ & $\begin{array}{c}0.005 \\
(0.036)\end{array}$ \\
\hline $45-54$ years & $\begin{array}{c}-0.242^{* * *} \\
(0.030)\end{array}$ & $\begin{array}{c}-0.086^{* *} \\
(0.034)\end{array}$ & $\begin{array}{c}-0.355^{* * *} \\
(0.040)\end{array}$ & $\begin{array}{l}-0.082^{*} \\
(0.043)\end{array}$ & $\begin{array}{c}-0.151^{* * *} \\
(0.046)\end{array}$ \\
\hline $55-64$ years & $\begin{array}{c}-0.231^{* * *} \\
(0.042)\end{array}$ & $\begin{array}{l}-0.038 \\
(0.049)\end{array}$ & $\begin{array}{c}-0.291^{* * *} \\
(0.056)\end{array}$ & $\begin{array}{l}-0.044 \\
(0.058)\end{array}$ & $\begin{array}{c}-0.151^{* *} \\
(0.063)\end{array}$ \\
\hline $\mathrm{WL} \times 35-44$ years & $\begin{array}{c}0.035 \\
(0.072)\end{array}$ & $\begin{array}{l}0.174^{*} \\
(0.093)\end{array}$ & $\begin{array}{c}0.320^{* *} \\
(0.137)\end{array}$ & $\begin{array}{c}0.083 \\
(0.118)\end{array}$ & $\begin{array}{l}-0.015 \\
(0.155)\end{array}$ \\
\hline $\mathrm{WL} \times 45-54$ years & $\begin{array}{c}0.042 \\
(0.096)\end{array}$ & $\begin{array}{c}0.235^{* *} \\
(0.115)\end{array}$ & $\begin{array}{c}0.429 * * * \\
(0.158)\end{array}$ & $\begin{array}{c}0.050 \\
(0.144)\end{array}$ & $\begin{array}{c}0.067 \\
(0.169)\end{array}$ \\
\hline $\mathrm{WL} \times 55-64$ years & $\begin{array}{c}0.045 \\
(0.111)\end{array}$ & $\begin{array}{l}0.269^{*} \\
(0.140)\end{array}$ & $\begin{array}{c}0.504^{* * *} \\
(0.174)\end{array}$ & $\begin{array}{l}-0.032 \\
(0.175)\end{array}$ & $\begin{array}{c}0.101 \\
(0.196)\end{array}$ \\
\hline $\mathrm{N}$ & 122,456 & 122,456 & 68,782 & 111,288 & 78,016 \\
\hline $\mathbf{X}_{i t}$ & $\checkmark$ & $\checkmark$ & $\checkmark$ & $\checkmark$ & $\checkmark$ \\
\hline
\end{tabular}

Source: SOEP (2019). Own calculations.

Note: Clustered standard errors in parentheses. ${ }^{*} p<0.1,{ }^{* *} p<0.05,{ }^{* * *} p<0.01$. 
Supplementary online material

Figure S.1: Life satisfaction at age 17 and gender disparity of first occupation

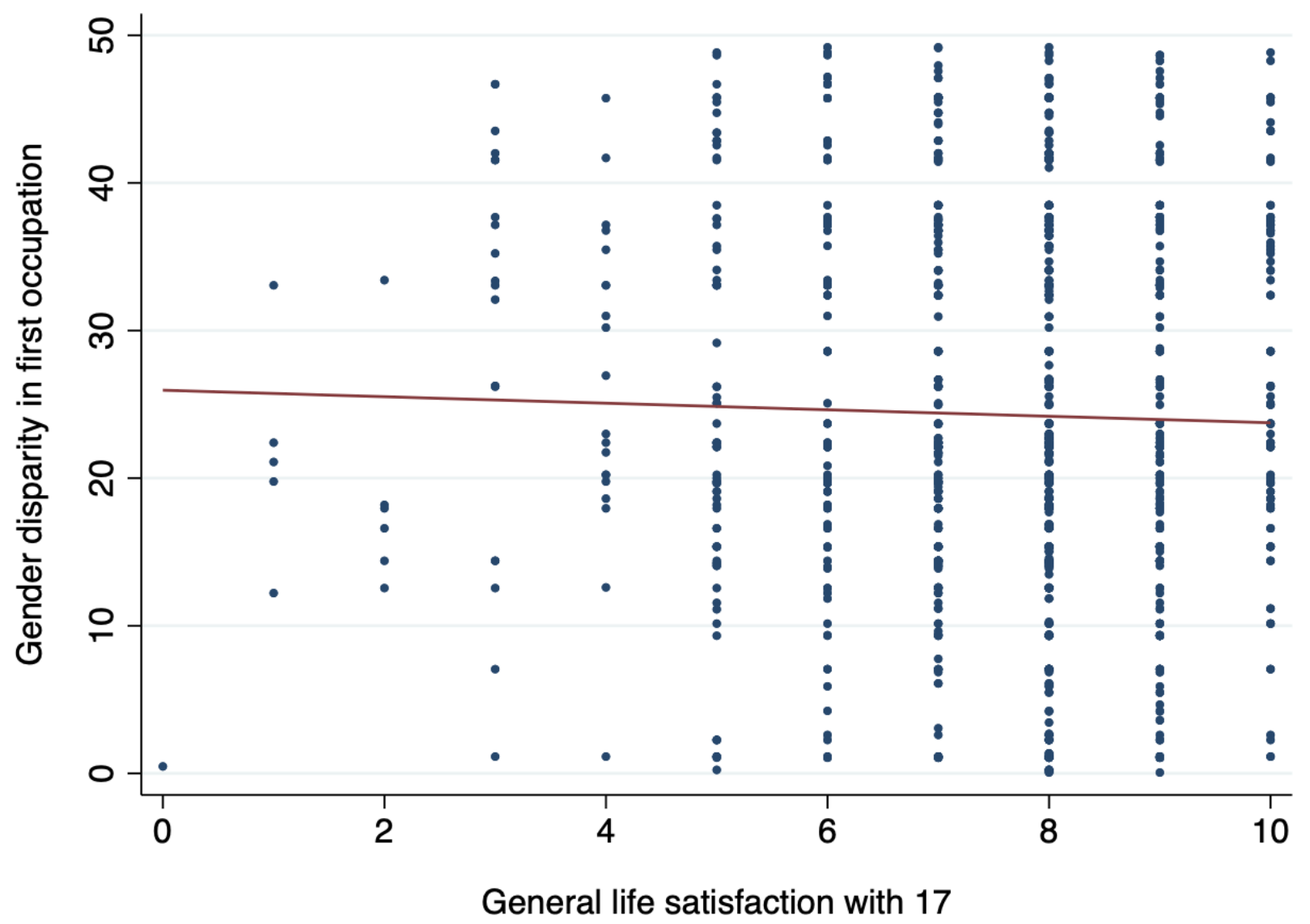

Source: SOEP 2019; Bundeagentur für Arbeit 2016a b. Own calculations and illustration.

Notes: Sample of 1178 adolescence with no own income at age 17 (2008-2018). 
Figure S.2: Share of female employees in occupations 1999 and 2016

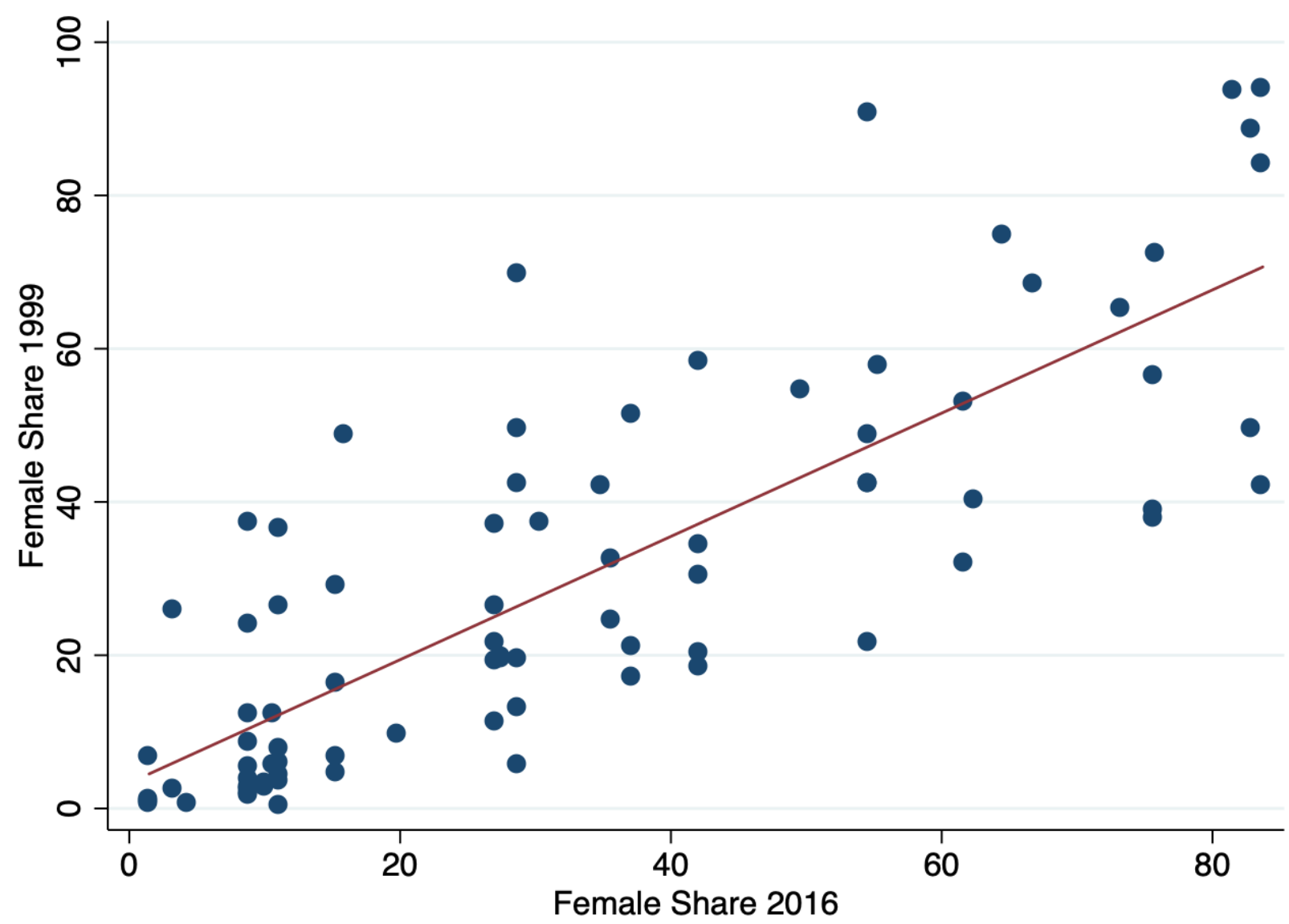

Source: Bundeagentur für Arbeit 2016a b). Own illustration.

Notes: Data points refer to 82 occupations classified using the KIdB88 classification for the year 1999 . Due to a change in the occupational classification around the year 2010 (from Kldb988 to Kldb10), occupations in 2016 (classified using Kldb10) cannot be matched directly to the occupations in 1999 but have to be grouped using a translation table available from the German Federal Employment Agency. If multiple Kldb10-occupations refer to a single Kldb8 occupation, the occupation with the largest overlap is merged. In some cases this can lead to an inaccurate match such that observed changes in the female shares are driven by the new classification. 
Table S.1: Robustness checks - Sample selection

\begin{tabular}{|c|c|c|c|c|c|c|c|c|c|c|c|c|c|c|c|}
\hline & $\begin{array}{c}\text { OLS } \\
(1)\end{array}$ & $\begin{array}{l}\text { Life } \\
\text { IV1 } \\
(2)\end{array}$ & $\begin{array}{c}\text { IV2 } \\
(3)\end{array}$ & $\begin{array}{c}\text { OLS } \\
(4)\end{array}$ & $\begin{array}{c}\text { Work } \\
\text { IV1 } \\
(5)\end{array}$ & $\begin{array}{c}\text { IV2 } \\
(6)\end{array}$ & $\begin{array}{c}\text { OLS } \\
(7)\end{array}$ & $\begin{array}{l}\text { Family } \\
\text { IV1 } \\
(8)\end{array}$ & $\begin{array}{c}\text { IV2 } \\
(9)\end{array}$ & $\begin{array}{c}\text { OLS } \\
(10)\end{array}$ & $\begin{array}{c}\text { Leisure } \\
\text { IV1 } \\
(11) \\
\end{array}$ & $\begin{array}{l}\text { IV2 } \\
(12)\end{array}$ & $\begin{array}{c}\text { OLS } \\
(13)\end{array}$ & $\begin{array}{c}\text { Income } \\
\text { IV1 } \\
(14)\end{array}$ & $\begin{array}{l}\text { IV2 } \\
(15)\end{array}$ \\
\hline \multicolumn{16}{|c|}{ Baseline } \\
\hline WL & $\begin{array}{l}0.082^{*} \\
(0.046)\end{array}$ & $\begin{array}{c}0.482^{* * *} \\
(0.105)\end{array}$ & $\begin{array}{c}0.441^{* * *} \\
(0.098)\end{array}$ & $\begin{array}{c}0.070 \\
(0.051)\end{array}$ & $\begin{array}{c}0.476^{* * *} \\
(0.101)\end{array}$ & $\begin{array}{c}0.408^{* * *} \\
(0.131)\end{array}$ & $\begin{array}{c}-0.000 \\
(0.063)\end{array}$ & $\begin{array}{c}0.252^{* *} \\
(0.126)\end{array}$ & $\begin{array}{c}0.279^{* *} \\
(0.114)\end{array}$ & $\begin{array}{c}-0.213^{* * *} \\
(0.065)\end{array}$ & $\begin{array}{c}0.139 \\
(0.269)\end{array}$ & $\begin{array}{c}0.026 \\
(0.256)\end{array}$ & $\begin{array}{c}0.229^{* * *} \\
(0.065)\end{array}$ & $\begin{array}{c}0.964^{* * *} \\
(0.164)\end{array}$ & $\begin{array}{c}0.792^{* * *} \\
(0.212)\end{array}$ \\
\hline $\mathrm{N}$ & 122456 & 122456 & 98153 & 122456 & 122456 & 98153 & 68782 & 68782 & 58711 & 111288 & 111288 & 89357 & 78016 & 78016 & 66279 \\
\hline \multicolumn{16}{|c|}{ 1a) Incl. non dual-earner couples } \\
\hline WL & $\begin{array}{c}0.054 \\
(0.048)\end{array}$ & $\begin{array}{c}0.482^{* * *} \\
(0.127)\end{array}$ & $\begin{array}{c}0.477^{* * *} \\
(0.106)\end{array}$ & $\begin{array}{c}0.046 \\
(0.051)\end{array}$ & $\begin{array}{c}0.444^{* * *} \\
(0.102)\end{array}$ & $\begin{array}{c}0.370^{* * *} \\
(0.134)\end{array}$ & $\begin{array}{c}-0.020 \\
(0.061)\end{array}$ & $\begin{array}{c}0.275^{* *} \\
(0.118)\end{array}$ & $\begin{array}{c}0.289^{* * *} \\
(0.106)\end{array}$ & $\begin{array}{c}-0.214^{* * *} \\
(0.065)\end{array}$ & $\begin{array}{c}0.207 \\
(0.258)\end{array}$ & $\begin{array}{c}0.212 \\
(0.185)\end{array}$ & $\begin{array}{c}0.211^{* * *} \\
(0.064)\end{array}$ & $\begin{array}{c}0.932^{* * *} \\
(0.154)\end{array}$ & $\begin{array}{c}0.789^{* * *} \\
(0.206)\end{array}$ \\
\hline $\mathrm{N}$ & 158190 & 158190 & 124670 & 137916 & 137916 & 109737 & 85350 & 85350 & 72142 & 144808 & 144808 & 114286 & 86633 & 86633 & 73142 \\
\hline \multicolumn{16}{|c|}{ 1b) Only non dual-earner couples } \\
\hline WL & $\begin{array}{c}-0.178 \\
(0.122)\end{array}$ & $\begin{array}{c}0.273 \\
(0.281)\end{array}$ & $\begin{array}{c}0.475^{* *} \\
(0.220)\end{array}$ & $\begin{array}{c}-0.367^{* * *} \\
(0.138)\end{array}$ & $\begin{array}{c}0.011 \\
(0.254)\end{array}$ & $\begin{array}{c}0.176 \\
(0.231)\end{array}$ & $\begin{array}{c}-0.161 \\
(0.148)\end{array}$ & $\begin{array}{c}0.259 \\
(0.217)\end{array}$ & $\begin{array}{c}0.217 \\
(0.192)\end{array}$ & $\begin{array}{l}-0.167 \\
(0.157)\end{array}$ & $\begin{array}{l}-0.185 \\
(0.906)\end{array}$ & $\begin{array}{c}0.422 \\
(0.314)\end{array}$ & $\begin{array}{c}-0.196 \\
(0.195)\end{array}$ & $\begin{array}{c}0.726^{* *} \\
(0.301)\end{array}$ & $\begin{array}{c}0.422 \\
(0.368)\end{array}$ \\
\hline $\mathrm{N}$ & 35734 & 35734 & 26517 & 15460 & 15460 & 11584 & 16568 & 16568 & 13431 & 33520 & 33520 & 24929 & 8617 & 8617 & 6863 \\
\hline \multicolumn{16}{|c|}{ 2) Incl. same sex couples } \\
\hline WL & $\begin{array}{l}0.080^{*} \\
(0.046)\end{array}$ & $\begin{array}{c}0.481^{* * *} \\
(0.105)\end{array}$ & $\begin{array}{c}0.448^{* * *} \\
(0.096)\end{array}$ & $\begin{array}{c}0.065 \\
(0.051)\end{array}$ & $\begin{array}{c}0.473^{* * *} \\
(0.101)\end{array}$ & $\begin{array}{c}0.390^{* * *} \\
(0.132)\end{array}$ & $\begin{array}{c}0.003 \\
(0.062)\end{array}$ & $\begin{array}{c}0.249^{* *} \\
(0.125)\end{array}$ & $\begin{array}{c}0.284^{* *} \\
(0.113)\end{array}$ & $\begin{array}{c}-0.219^{* * *} \\
(0.065)\end{array}$ & $\begin{array}{c}0.140 \\
(0.263)\end{array}$ & $\begin{array}{c}0.120 \\
(0.225)\end{array}$ & $\begin{array}{c}0.233^{* * *} \\
(0.065)\end{array}$ & $\begin{array}{c}0.972^{* * *} \\
(0.164)\end{array}$ & $\begin{array}{r}0.866^{* * *} \\
(0.205)\end{array}$ \\
\hline $\mathrm{N}$ & 122992 & 122992 & 98599 & 122992 & 122992 & 98599 & 69207 & 69207 & 59065 & 111810 & 111810 & 89794 & 78477 & 78477 & 66665 \\
\hline \multicolumn{16}{|c|}{ 3) Excl. missing paternal occupation } \\
\hline WL & $\begin{array}{l}0.084^{*} \\
(0.051)\end{array}$ & $\begin{array}{c}0.467^{* * *} \\
(0.098)\end{array}$ & & $\begin{array}{c}0.064 \\
(0.058)\end{array}$ & $\begin{array}{c}0.471^{* * *} \\
(0.103)\end{array}$ & & $\begin{array}{l}-0.008 \\
(0.066)\end{array}$ & $\begin{array}{c}0.254^{* *} \\
(0.127)\end{array}$ & & $\begin{array}{c}-0.152^{* *} \\
(0.070)\end{array}$ & $\begin{array}{c}0.176 \\
(0.265)\end{array}$ & & & $\begin{array}{c}0.232^{* * *} \\
(0.068)\end{array}$ & $\begin{array}{c}0.925^{* * *} \\
(0.185)\end{array}$ \\
\hline $\mathrm{N}$ & 98153 & 98153 & & 98153 & 98153 & & 58711 & 58711 & & 89357 & 89357 & & & 66279 & 66279 \\
\hline $\mathbf{X}_{i t}$ & $\checkmark$ & $\checkmark$ & $\checkmark$ & $\checkmark$ & $\checkmark$ & $\checkmark$ & $\checkmark$ & $\checkmark$ & $\checkmark$ & $\checkmark$ & $\checkmark$ & $\checkmark$ & $\checkmark$ & $\checkmark$ & $\checkmark$ \\
\hline
\end{tabular}

Source: [SOEP [2019]; $[$ Bundeagentur für Arbeit $[2016 \mathrm{a}$ b]. Own calculations.
Note: Clustered standard errors in parentheses do not include federal state and self-employment indicators. The baseline results thus slightly differ from the main estimation results. Estimations in panel 1b), columns (11) and (12) do not include occupation FE due to non-convergence. 
Table S.2: First stage estimation results - Reduced samples

\begin{tabular}{|c|c|c|c|}
\hline & All & Men & Women \\
\hline \multicolumn{4}{|c|}{ Sample: Family satisfaction (2006-2018) } \\
\hline Occ./Ind. gender disparity & $\begin{array}{l}-0.013^{* * *} \\
(0.003)\end{array}$ & $\begin{array}{l}-0.015^{* * *} \\
(0.003)\end{array}$ & $\begin{array}{l}-0.009^{* *} \\
(0.004)\end{array}$ \\
\hline F-statistic & 9.07 & 13.51 & 3.21 \\
\hline $\mathrm{N}$ & 68782 & 34378 & 34404 \\
\hline $\mathrm{P}(\mathrm{WL} \mid \mathrm{PPO})$ & $\begin{array}{l}0.009 * * * \\
(0.003)\end{array}$ & $\begin{array}{l}0.006^{*} \\
(0.004)\end{array}$ & $\begin{array}{l}0.010^{* * *} \\
(0.004)\end{array}$ \\
\hline F-statistic & 9.31 & 2.65 & 6.16 \\
\hline $\mathrm{N}$ & 58711 & 29281 & 29430 \\
\hline \multicolumn{4}{|c|}{ Sample: Leisure satisfaction (with gaps) } \\
\hline Occ./Ind. gender disparity & $\begin{array}{l}-0.011^{* * *} \\
(0.003)\end{array}$ & $\begin{array}{l}-0.015^{* * *} \\
(0.003)\end{array}$ & $\begin{array}{l}-0.006 \\
(0.004)\end{array}$ \\
\hline F-statistic & 9.88 & 16.28 & 2.19 \\
\hline $\mathrm{N}$ & 111288 & 55648 & 55640 \\
\hline $\mathrm{P}(\mathrm{WL} \mid \mathrm{PPO})$ & $\begin{array}{l}0.010^{* * *} \\
(0.002)\end{array}$ & $\begin{array}{l}0.008^{* * *} \\
(0.003)\end{array}$ & $\begin{array}{l}0.011^{* * *} \\
(0.003)\end{array}$ \\
\hline F-statistic & 16.29 & 6.07 & 11.45 \\
\hline $\mathrm{N}$ & 89357 & 44972 & 44385 \\
\hline \multicolumn{4}{|c|}{ Sample: Income satisfaction (2004-2018) } \\
\hline Occ./Ind. gender disparity & $\begin{array}{l}-0.013^{* * *} \\
(0.003)\end{array}$ & $\begin{array}{l}-0.015^{* * *} \\
(0.003)\end{array}$ & $\begin{array}{l}-0.009 * * \\
(0.004)\end{array}$ \\
\hline F-statistic & 9.10 & 13.34 & 3.35 \\
\hline $\mathrm{N}$ & 78016 & 39012 & 39004 \\
\hline $\mathrm{P}(\mathrm{WL} \mid \mathrm{PPO})$ & $\begin{array}{l}0.009 * * * \\
(0.003)\end{array}$ & $\begin{array}{l}0.007^{*} \\
(0.004)\end{array}$ & $\begin{array}{l}0.009 * * * \\
(0.004)\end{array}$ \\
\hline F-statistic & 10.59 & 3.66 & 6.68 \\
\hline $\mathrm{N}$ & 66279 & 33104 & 33175 \\
\hline
\end{tabular}

Source: SOEP $(2019) ;$ Bundeagentur für Arbeit $(2016 \mathrm{a}$ b). Own calculations.

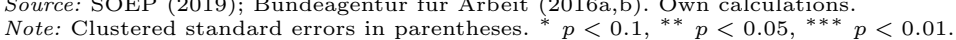

Table S.3: Robustness checks - $t F$ test procedure for weak instrument

\begin{tabular}{|c|c|c|c|c|c|c|c|c|c|c|}
\hline & \multicolumn{2}{|c|}{ Life } & \multicolumn{2}{|c|}{ Work } & \multicolumn{2}{|c|}{ Family } & \multicolumn{2}{|c|}{ Leisure } & \multicolumn{2}{|c|}{ Income } \\
\hline & $\begin{array}{c}\text { IV } 1 \\
(1)\end{array}$ & $\begin{array}{c}\text { IV } 2 \\
(2)\end{array}$ & $\begin{array}{c}\text { IV } 1 \\
(3)\end{array}$ & $\begin{array}{c}\text { IV } 2 \\
(4)\end{array}$ & $\begin{array}{c}\mathrm{IV} 1 \\
(5)\end{array}$ & $\begin{array}{c}\text { IV } 2 \\
(6)\end{array}$ & $\begin{array}{c}\text { IV } 1 \\
(7)\end{array}$ & $\begin{array}{c}\text { IV } 2 \\
(8)\end{array}$ & $\begin{array}{c}\text { IV } 1 \\
(9)\end{array}$ & $\begin{array}{c}\text { IV } 2 \\
(10)\end{array}$ \\
\hline \multicolumn{11}{|l|}{ All } \\
\hline First stage F-statistic & 10.13 & 16.01 & 10.13 & 16.01 & 9.07 & 9.31 & 9.88 & 16.29 & 9.1 & 10.59 \\
\hline $\operatorname{SQRT}(\mathrm{F})$ & 3.2 & 4.0 & 3.2 & 4.0 & 3.0 & 3.1 & 3.1 & 4.0 & 3.0 & 3.3 \\
\hline Critical t & 3.39 & 2.8 & 3.39 & 2.8 & 3.65 & 3.51 & 3.51 & 2.8 & 3.65 & 3.29 \\
\hline $\mathrm{b}$ & 0.397 & 0.441 & 0.412 & 0.408 & 0.221 & 0.279 & 0.003 & 0.026 & 0.847 & 0.792 \\
\hline $\mathrm{tF} 0.05 \mathrm{SE}$ & 0.199 & 0.140 & 0.216 & 0.187 & 0.253 & 0.204 & 0.428 & 0.366 & 0.352 & 0.356 \\
\hline $\mathrm{tF}$ corrected $\mathrm{t}$ & 1.996 & 3.150 & 1.906 & 2.180 & 0.873 & 1.367 & 0.007 & 0.071 & 2.406 & 2.226 \\
\hline \multicolumn{11}{|l|}{ Men } \\
\hline First stage F-statistic & 17.16 & 5.95 & 17.16 & 5.95 & 13.51 & 2.65 & 16.28 & 6.07 & 13.34 & 3.66 \\
\hline Critical t & 1.96 & 5.43 & 1.96 & 5.43 & 2.04 & 18.66 & 1.96 & 5.43 & 2.03 & 18.66 \\
\hline $\mathrm{b}$ & 0.379 & 0.493 & 0.271 & 0.363 & 0.158 & 0.288 & -0.072 & 0.012 & 0.665 & 0.689 \\
\hline $\mathrm{tF} 0.05 \mathrm{SE}$ & 0.151 & 0.291 & 0.241 & 0.518 & 0.167 & 1.114 & 0.259 & 0.684 & 0.190 & 2.285 \\
\hline $\mathrm{tF}$ corrected $\mathrm{t}$ & 2.510 & 1.695 & 1.124 & 0.701 & 0.949 & 0.259 & -0.278 & 0.018 & 3.509 & 0.302 \\
\hline \multicolumn{11}{|l|}{ Women } \\
\hline First stage F-statistic & 1.99 & 11.2 & 1.99 & 11.2 & 3.21 & 6.16 & 2.19 & 11.45 & 3.35 & 6.68 \\
\hline Critical t & 3.19 & 3.11 & 3.19 & 3.11 & 2.71 & 4.92 & 3.11 & 3.11 & 2.63 & 4.25 \\
\hline $\mathrm{b}$ & 0.353 & 0.342 & 0.492 & 0.475 & 0.265 & 0.252 & 0.151 & 0.129 & 1.072 & 0.987 \\
\hline $\mathrm{tF} 0.05 \mathrm{SE}$ & 0.199 & 0.222 & 0.228 & 0.225 & 0.178 & 0.361 & 0.351 & 0.455 & 0.386 & 0.553 \\
\hline $\mathrm{tF}$ corrected $\mathrm{t}$ & 1.778 & 1.540 & 2.159 & 2.108 & 1.486 & 0.697 & 0.431 & 0.283 & 2.774 & 1.785 \\
\hline
\end{tabular}

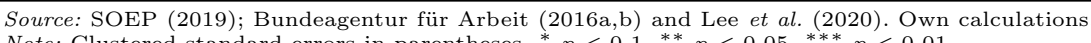

Note: Clustered standard errors in parentheses. $p<0.1, * * \frac{2}{p<0.05, * *} p<0.01$. 
Table S.4: Reduced form estimation - All individuals

\begin{tabular}{|c|c|c|c|c|c|}
\hline $\mathbf{Y}_{i t}$ & $\begin{array}{l}\text { Life } \\
\mathrm{b} / \mathrm{se}\end{array}$ & $\begin{array}{l}\text { Work } \\
\mathrm{b} / \mathrm{se}\end{array}$ & $\begin{array}{l}\text { Family } \\
\text { b / se }\end{array}$ & $\begin{array}{c}\text { Leisure } \\
\text { b / se }\end{array}$ & $\begin{array}{l}\text { Income } \\
\mathrm{b} / \mathrm{se}\end{array}$ \\
\hline Occ./ ind. gender disparity & $\begin{array}{l}-0.001 \\
(0.001)\end{array}$ & $\begin{array}{l}-0.001 \\
(0.001)\end{array}$ & $\begin{array}{l}-0.000 \\
(0.001)\end{array}$ & $\begin{array}{l}0.000 \\
(0.002)\end{array}$ & $\begin{array}{l}-0.003 \\
(0.002)\end{array}$ \\
\hline $\mathrm{N}$ & 122456 & 122456 & 68782 & 111288 & 78016 \\
\hline $\mathrm{P}(\mathrm{WL} \mid \mathrm{PPO})$ & $\begin{array}{l}0.002 \\
(0.001)\end{array}$ & $\begin{array}{l}-0.001 \\
(0.002)\end{array}$ & $\begin{array}{l}0.003^{*} \\
(0.002)\end{array}$ & $\begin{array}{l}-0.001 \\
(0.002)\end{array}$ & $\begin{array}{l}0.002 \\
(0.002)\end{array}$ \\
\hline $\mathrm{N}$ & 98154 & 98154 & 58710 & 89359 & 66278 \\
\hline WL & $\checkmark$ & $\checkmark$ & $\checkmark$ & $\checkmark$ & $\checkmark$ \\
\hline $\mathbf{X}_{i t}$ & $\checkmark$ & $\checkmark$ & $\checkmark$ & $\checkmark$ & $\checkmark$ \\
\hline
\end{tabular}

Source: SOEP $(2019) ;$ Bundeagentur für Arbeit $(2016 \mathrm{a}$ b). Own calculations

Source: SOEP
Note: Clustered standard errors in parentheses. 
Table S.5: Full estimation results - Conditional OLS

\begin{tabular}{|c|c|c|c|c|c|}
\hline & Life & Work & Family & Leisure & Income \\
\hline Work-Linked & $\begin{array}{l}0.083^{*} \\
(0.046)\end{array}$ & $\begin{array}{c}0.060 \\
(0.051)\end{array}$ & $\begin{array}{c}0.003 \\
(0.062)\end{array}$ & $\begin{array}{c}-0.161^{* *} \\
(0.063)\end{array}$ & $\begin{array}{c}0.221^{* * *} \\
(0.063)\end{array}$ \\
\hline \multicolumn{6}{|l|}{ Individual characteristics } \\
\hline Female & $\begin{array}{c}0.011 \\
(0.018)\end{array}$ & $\begin{array}{c}0.022 \\
(0.025)\end{array}$ & $\begin{array}{c}-0.135^{* * *} \\
(0.023)\end{array}$ & $\begin{array}{l}-0.283^{* * *} \\
(0.029)\end{array}$ & $\begin{array}{c}-0.087^{* * *} \\
(0.033)\end{array}$ \\
\hline \multicolumn{6}{|l|}{ Age (Ref.: 25-34 years) } \\
\hline $35-44$ years & $\begin{array}{c}-0.126^{* * *} \\
(0.021)\end{array}$ & $\begin{array}{l}-0.011 \\
(0.025)\end{array}$ & $\begin{array}{c}-0.199^{* * *} \\
(0.031)\end{array}$ & $\begin{array}{l}-0.047 \\
(0.031)\end{array}$ & $\begin{array}{c}0.004 \\
(0.036)\end{array}$ \\
\hline 45-54 years & $\begin{array}{c}-0.240^{* * *} \\
(0.029)\end{array}$ & $\begin{array}{c}-0.074^{* *} \\
(0.033)\end{array}$ & $\begin{array}{c}-0.334^{* * *} \\
(0.040)\end{array}$ & $\begin{array}{r}-0.080^{*} \\
(0.043)\end{array}$ & $\begin{array}{c}-0.148^{* * *} \\
(0.046)\end{array}$ \\
\hline 55-64 years & $\begin{array}{c}-0.228^{* * *} \\
(0.041)\end{array}$ & $\begin{array}{l}-0.023 \\
(0.048)\end{array}$ & $\begin{array}{c}-0.263^{* * *} \\
(0.055)\end{array}$ & $\begin{array}{l}-0.046 \\
(0.058)\end{array}$ & $\begin{array}{c}-0.145^{* *} \\
(0.063)\end{array}$ \\
\hline Years of education & $\begin{array}{c}0.018^{* * *} \\
(0.004)\end{array}$ & $\begin{array}{c}0.003 \\
(0.005)\end{array}$ & $\begin{array}{c}-0.017^{* * *} \\
(0.005)\end{array}$ & $\begin{array}{c}-0.014^{* *} \\
(0.006)\end{array}$ & $\begin{array}{c}0.077^{* * *} \\
(0.006)\end{array}$ \\
\hline Self-employed & $\begin{array}{l}-0.046 \\
(0.035)\end{array}$ & $\begin{array}{c}0.269^{* * *} \\
(0.043)\end{array}$ & $\begin{array}{c}-0.165^{* * *} \\
(0.047)\end{array}$ & $\begin{array}{c}-1.094^{* * *} \\
(0.060)\end{array}$ & $\begin{array}{c}0.335^{* * *} \\
(0.063)\end{array}$ \\
\hline Tenure (in years) & $\begin{array}{c}0.005^{* * *} \\
(0.001)\end{array}$ & $\begin{array}{c}-0.008^{* * *} \\
(0.001)\end{array}$ & $\begin{array}{c}0.002 \\
(0.001)\end{array}$ & $\begin{array}{c}0.012^{* * *} \\
(0.002)\end{array}$ & $\begin{array}{c}0.017^{* * *} \\
(0.002)\end{array}$ \\
\hline $\begin{array}{l}\text { Firm size (Ref.: small, under } 20 \text { em } \\
\text { medium }(20-199)\end{array}$ & $\begin{array}{c}0.030 \\
(0.023)\end{array}$ & $\begin{array}{c}-0.067^{* *} \\
(0.028)\end{array}$ & $\begin{array}{c}-0.051^{*} \\
(0.031)\end{array}$ & $\begin{array}{c}0.028 \\
(0.035)\end{array}$ & $\begin{array}{c}0.219^{* * *} \\
(0.038)\end{array}$ \\
\hline large (200 and more) & $\begin{array}{c}0.050^{* *} \\
(0.024)\end{array}$ & $\begin{array}{l}-0.032 \\
(0.029)\end{array}$ & $\begin{array}{c}-0.051^{*} \\
(0.030)\end{array}$ & $\begin{array}{c}0.009 \\
(0.035)\end{array}$ & $\begin{array}{c}0.500^{* * *} \\
(0.039)\end{array}$ \\
\hline In trained occupation & $\begin{array}{c}0.102^{* * * *} \\
(0.018)\end{array}$ & $\begin{array}{c}0.194^{* * *} \\
(0.023)\end{array}$ & $\begin{array}{c}0.038 \\
(0.024)\end{array}$ & $\begin{array}{c}0.004 \\
(0.027)\end{array}$ & $\begin{array}{c}0.268^{* * *} \\
(0.030)\end{array}$ \\
\hline Fixed-term contract & $\begin{array}{c}-0.140^{* * *} \\
(0.025)\end{array}$ & $\begin{array}{c}-0.122^{* * *} \\
(0.031)\end{array}$ & $\begin{array}{c}-0.071^{* *} \\
(0.031)\end{array}$ & $\begin{array}{c}-0.166^{* * *} \\
(0.036)\end{array}$ & $\begin{array}{c}-0.428^{* * *} \\
(0.042)\end{array}$ \\
\hline Full-time employed & $\begin{array}{c}-0.077^{* * *} \\
(0.022)\end{array}$ & $\begin{array}{l}-0.008 \\
(0.027)\end{array}$ & $\begin{array}{c}-0.099^{* * *} \\
(0.029)\end{array}$ & $\begin{array}{c}-0.562^{* * *} \\
(0.032)\end{array}$ & $\begin{array}{c}0.341^{* * *} \\
(0.036)\end{array}$ \\
\hline \multicolumn{6}{|l|}{ Household characteristics } \\
\hline Married & $\begin{array}{c}0.122^{* * *} \\
(0.032)\end{array}$ & $\begin{array}{c}0.098^{* * *} \\
(0.035)\end{array}$ & $\begin{array}{c}0.298^{* * *} \\
(0.044)\end{array}$ & $\begin{array}{l}-0.025 \\
(0.044)\end{array}$ & $\begin{array}{c}0.063 \\
(0.046)\end{array}$ \\
\hline Number of children in $\mathrm{HH}$ & $\begin{array}{c}0.008 \\
(0.011)\end{array}$ & $\begin{array}{c}0.046^{* * *} \\
(0.012)\end{array}$ & $\begin{array}{c}-0.036^{* *} \\
(0.016)\end{array}$ & $\begin{array}{c}-0.207^{* * *} \\
(0.016)\end{array}$ & $\begin{array}{c}-0.032^{* *} \\
(0.016)\end{array}$ \\
\hline Partnership length & $\begin{array}{c}-0.027^{* * *} \\
(0.002)\end{array}$ & $\begin{array}{c}-0.015^{* * *} \\
(0.002)\end{array}$ & $\begin{array}{c}-0.021^{* * *} \\
(0.002)\end{array}$ & $\begin{array}{c}-0.009^{* * *} \\
(0.003)\end{array}$ & $\begin{array}{c}-0.012^{* * *} \\
(0.003)\end{array}$ \\
\hline Censored partnership length & $\begin{array}{c}0.001 \\
(0.029)\end{array}$ & $\begin{array}{l}0.058^{*} \\
(0.032)\end{array}$ & $\begin{array}{c}0.043 \\
(0.036)\end{array}$ & $\begin{array}{c}0.013 \\
(0.039)\end{array}$ & $\begin{array}{c}0.080^{* *} \\
(0.040)\end{array}$ \\
\hline \multicolumn{6}{|l|}{ Partner characteristics } \\
\hline Years of education & $\begin{array}{c}0.014^{* * *} \\
(0.003)\end{array}$ & $\begin{array}{c}-0.014^{* * *} \\
(0.005)\end{array}$ & $\begin{array}{c}-0.007^{*} \\
(0.004)\end{array}$ & $\begin{array}{c}0.022^{* * *} \\
(0.005)\end{array}$ & $\begin{array}{c}0.022^{* * *} \\
(0.006)\end{array}$ \\
\hline Tenure & $\begin{array}{c}0.005^{* * *} \\
(0.001)\end{array}$ & $\begin{array}{c}-0.001 \\
(0.001)\end{array}$ & $\begin{array}{c}0.003^{* *} \\
(0.001)\end{array}$ & $\begin{array}{c}0.009^{* * *} \\
(0.001)\end{array}$ & $\begin{array}{c}0.002 \\
(0.002)\end{array}$ \\
\hline In trained occupation & $\begin{array}{c}0.075^{* * *} \\
(0.017)\end{array}$ & $\begin{array}{c}0.011 \\
(0.021)\end{array}$ & $\begin{array}{c}0.070^{* * *} \\
(0.023)\end{array}$ & $\begin{array}{c}0.015 \\
(0.026)\end{array}$ & $\begin{array}{c}0.021 \\
(0.028)\end{array}$ \\
\hline Fixed-term contract & $\begin{array}{c}-0.068^{* * *} \\
(0.025)\end{array}$ & $\begin{array}{c}-0.041 \\
(0.030)\end{array}$ & $\begin{array}{l}-0.050 \\
(0.032)\end{array}$ & $\begin{array}{c}-0.038 \\
(0.035)\end{array}$ & $\begin{array}{l}-0.035 \\
(0.038)\end{array}$ \\
\hline Full-time employed & $\begin{array}{l}-0.030 \\
(0.019)\end{array}$ & $\begin{array}{c}-0.080^{* * *} \\
(0.023)\end{array}$ & $\begin{array}{c}-0.047^{*} \\
(0.025)\end{array}$ & $\begin{array}{c}0.020 \\
(0.029)\end{array}$ & $\begin{array}{c}-0.192^{* * *} \\
(0.031)\end{array}$ \\
\hline \multicolumn{6}{|l|}{ Regional characteristics } \\
\hline Rural area & $\begin{array}{l}-0.009 \\
(0.031)\end{array}$ & $\begin{array}{c}0.002 \\
(0.034)\end{array}$ & $\begin{array}{c}0.014 \\
(0.037)\end{array}$ & $\begin{array}{l}-0.002 \\
(0.043)\end{array}$ & $\begin{array}{l}-0.017 \\
(0.044)\end{array}$ \\
\hline \multicolumn{6}{|l|}{ Federal state (Ref.: Schleswig-Holstein) } \\
\hline Hamburg & $\begin{array}{c}-0.173^{*} \\
(0.092)\end{array}$ & $\begin{array}{l}-0.176 \\
(0.120)\end{array}$ & $\begin{array}{c}-0.009 \\
(0.113)\end{array}$ & $\begin{array}{c}-0.055 \\
(0.144)\end{array}$ & $\begin{array}{c}-0.049 \\
(0.142)\end{array}$ \\
\hline Lower Saxony & $\begin{array}{c}-0.295^{* * *} \\
(0.070)\end{array}$ & $\begin{array}{c}-0.127 \\
(0.087)\end{array}$ & $\begin{array}{c}-0.314^{* * *} \\
(0.080)\end{array}$ & $\begin{array}{c}-0.290^{* * *} \\
(0.110)\end{array}$ & $\begin{array}{l}-0.100 \\
(0.106)\end{array}$ \\
\hline Bremen & $\begin{array}{c}-0.337^{* *} \\
(0.171)\end{array}$ & $\begin{array}{c}-0.199 \\
(0.177)\end{array}$ & $\begin{array}{c}0.385^{* * *} \\
(0.145)\end{array}$ & $\begin{array}{c}-0.405^{* *} \\
(0.175)\end{array}$ & $\begin{array}{c}0.036 \\
(0.219)\end{array}$ \\
\hline North Rhine-Westphalia & $\begin{array}{c}-0.337^{* * *} \\
(0.067)\end{array}$ & $\begin{array}{c}-0.213^{* *} \\
(0.083)\end{array}$ & $\begin{array}{c}-0.252^{* * *} \\
(0.077)\end{array}$ & $\begin{array}{c}-0.384^{* * *} \\
(0.106)\end{array}$ & $\begin{array}{l}-0.160 \\
(0.102)\end{array}$ \\
\hline Hesse & $\begin{array}{c}-0.379^{* * *} \\
(0.073)\end{array}$ & $\begin{array}{c}-0.287^{* * *} \\
(0.089)\end{array}$ & $\begin{array}{c}-0.431^{* * *} \\
(0.086)\end{array}$ & $\begin{array}{c}-0.493^{* * *} \\
(0.114)\end{array}$ & $\begin{array}{c}-0.306^{* * *} \\
(0.110)\end{array}$ \\
\hline Rhinel.-Palatinate & $\begin{array}{c}-0.159^{* *} \\
(0.081)\end{array}$ & $\begin{array}{c}0.090 \\
(0.093)\end{array}$ & $\begin{array}{c}-0.192^{* *} \\
(0.096)\end{array}$ & $\begin{array}{c}-0.393^{* * *} \\
(0.124)\end{array}$ & $\begin{array}{c}0.125 \\
(0.117)\end{array}$ \\
\hline Baden-Wuerttemberg & $\begin{array}{c}-0.301^{* * *} \\
(0.070)\end{array}$ & $\begin{array}{c}-0.210^{* *} \\
(0.085)\end{array}$ & $\begin{array}{c}-0.342^{* * *} \\
(0.079)\end{array}$ & $\begin{array}{c}-0.568^{* * *} \\
(0.110)\end{array}$ & $\begin{array}{c}-0.195^{*} \\
(0.106)\end{array}$ \\
\hline Bavaria & $\begin{array}{c}-0.340^{* * *} \\
(0.068)\end{array}$ & $\begin{array}{c}-0.175^{* *} \\
(0.083)\end{array}$ & $\begin{array}{c}-0.321^{* * *} \\
(0.075)\end{array}$ & $\begin{array}{c}-0.253^{* *} \\
(0.106)\end{array}$ & $\begin{array}{l}-0.120 \\
(0.101)\end{array}$ \\
\hline Saarland & $\begin{array}{c}-0.388^{* *} \\
(0.156)\end{array}$ & $\begin{array}{c}-0.325^{*} \\
(0.184)\end{array}$ & $\begin{array}{c}-0.381^{*} \\
(0.208)\end{array}$ & $\begin{array}{c}-0.397^{*} \\
(0.210)\end{array}$ & $\begin{array}{l}-0.303 \\
(0.243)\end{array}$ \\
\hline Berlin & $\begin{array}{c}-0.597^{* * *} \\
(0.094)\end{array}$ & $\begin{array}{c}-0.552^{* * *} \\
(0.108)\end{array}$ & $\begin{array}{c}-0.533^{* * *} \\
(0.121)\end{array}$ & $\begin{array}{c}-0.474^{* * *} \\
(0.135)\end{array}$ & $\begin{array}{c}-0.593^{* * *} \\
(0.135)\end{array}$ \\
\hline Brandenburg & $\begin{array}{c}-0.750^{* * *} \\
(0.087)\end{array}$ & $\begin{array}{c}-0.451^{* * *} \\
(0.097)\end{array}$ & $\begin{array}{c}-0.397^{* * *} \\
(0.099)\end{array}$ & $\begin{array}{c}-0.676^{* * *} \\
(0.125)\end{array}$ & $\begin{array}{c}-0.518^{* * *} \\
(0.124)\end{array}$ \\
\hline Mecklenburg-Western Pomerania & $\begin{array}{c}-0.519^{* * *} \\
(0.093)\end{array}$ & $\begin{array}{c}-0.226^{*} \\
(0.116)\end{array}$ & $\begin{array}{c}-0.143 \\
(0.106)\end{array}$ & $\begin{array}{c}-0.406^{* * *} \\
(0.141)\end{array}$ & $\begin{array}{c}-0.165 \\
(0.150)\end{array}$ \\
\hline Saxony & $\begin{array}{c}-0.593^{* * *} \\
(0.076)\end{array}$ & $\begin{array}{c}-0.174^{* *} \\
(0.088)\end{array}$ & $\begin{array}{c}-0.323^{* * *} \\
(0.086)\end{array}$ & $\begin{array}{c}-0.581^{* * *} \\
(0.117)\end{array}$ & $\begin{array}{c}-0.467^{* * *} \\
(0.112)\end{array}$ \\
\hline Saxony-Anhalt & $\begin{array}{c}-0.759^{* * *} \\
(0.088)\end{array}$ & $\begin{array}{c}-0.388^{* * *} \\
(0.103)\end{array}$ & $\begin{array}{c}-0.330^{* * *} \\
(0.108)\end{array}$ & $\begin{array}{c}-0.776^{* * *} \\
(0.132)\end{array}$ & $\begin{array}{c}-0.542^{* * *} \\
(0.131)\end{array}$ \\
\hline Thuringia & $\begin{array}{c}-0.673^{* * *} \\
(0.084)\end{array}$ & $\begin{array}{c}-0.539^{* * *} \\
(0.101)\end{array}$ & $\begin{array}{c}-0.342^{* * *} \\
(0.098)\end{array}$ & $\begin{array}{c}-0.812^{* * *} \\
(0.130)\end{array}$ & $\begin{array}{c}-0.679^{* * *} \\
(0.130)\end{array}$ \\
\hline
\end{tabular}


Table S.5: Full Estimation Results - Conditional OLS (ctd.)

\begin{tabular}{|c|c|c|c|c|c|}
\hline & Life & Work & Family & Leisure & Income \\
\hline \multicolumn{6}{|l|}{ Kldb92 occupation (Ref.: Agricultural occupations) } \\
\hline Mining occupations & $\begin{array}{l}-0.150 \\
(0.319)\end{array}$ & $\begin{array}{c}-0.761^{* *} \\
(0.340)\end{array}$ & $\begin{array}{c}-0.012 \\
(0.385)\end{array}$ & $\begin{array}{c}0.465 \\
(0.354)\end{array}$ & $\begin{array}{c}-0.387 \\
(0.750)\end{array}$ \\
\hline Stone processors and construction material manufacturers & $\begin{array}{c}0.215 \\
(0.219)\end{array}$ & $\begin{array}{c}0.062 \\
(0.440)\end{array}$ & $\begin{array}{c}0.277 \\
(0.227)\end{array}$ & $\begin{array}{c}0.252 \\
(0.298)\end{array}$ & $\begin{array}{c}0.359 \\
(0.448)\end{array}$ \\
\hline Ceramists and glass manufacturing/processing & $\begin{array}{c}0.398^{* *} \\
(0.200)\end{array}$ & $\begin{array}{c}0.023 \\
(0.251)\end{array}$ & $\begin{array}{c}0.554^{* *} \\
(0.258)\end{array}$ & $\begin{array}{l}0.521^{*} \\
(0.292)\end{array}$ & $\begin{array}{c}-0.037 \\
(0.420)\end{array}$ \\
\hline Chemistry and synthetic materials & $\begin{array}{c}0.148 \\
(0.132)\end{array}$ & $\begin{array}{l}-0.063 \\
(0.152)\end{array}$ & $\begin{array}{c}0.373^{* *} \\
(0.172)\end{array}$ & $\begin{array}{c}0.252 \\
(0.179)\end{array}$ & $\begin{array}{c}0.054 \\
(0.210)\end{array}$ \\
\hline Paper manufacturing/processing and print & $\begin{array}{c}0.036 \\
(0.130)\end{array}$ & $\begin{array}{c}-0.308^{*} \\
(0.168)\end{array}$ & $\begin{array}{c}0.217 \\
(0.191)\end{array}$ & $\begin{array}{c}0.189 \\
(0.201)\end{array}$ & $\begin{array}{c}-0.414^{*} \\
(0.220)\end{array}$ \\
\hline Wood processing, wood/woven goods manufacturing & $\begin{array}{c}0.292 \\
(0.220)\end{array}$ & $\begin{array}{l}-0.175 \\
(0.382)\end{array}$ & $\begin{array}{c}0.298 \\
(0.239)\end{array}$ & $\begin{array}{c}0.649^{* *} \\
(0.316)\end{array}$ & $\begin{array}{c}-1.065^{* * *} \\
(0.401)\end{array}$ \\
\hline Metal manufacturing and processing & $\begin{array}{c}0.191 \\
(0.119)\end{array}$ & $\begin{array}{c}0.041 \\
(0.140)\end{array}$ & $\begin{array}{l}0.299^{*} \\
(0.159)\end{array}$ & $\begin{array}{c}0.257 \\
(0.164)\end{array}$ & $\begin{array}{l}-0.113 \\
(0.212)\end{array}$ \\
\hline Metal and plant engineering and related & $\begin{array}{c}0.050 \\
(0.096)\end{array}$ & $\begin{array}{c}-0.111 \\
(0.109)\end{array}$ & $\begin{array}{c}0.156 \\
(0.122)\end{array}$ & $\begin{array}{l}-0.015 \\
(0.146)\end{array}$ & $\begin{array}{c}-0.206 \\
(0.159)\end{array}$ \\
\hline Electrical prof. & $\begin{array}{c}0.149 \\
(0.109)\end{array}$ & $\begin{array}{c}0.006 \\
(0.123)\end{array}$ & $\begin{array}{c}0.163 \\
(0.141)\end{array}$ & $\begin{array}{c}0.087 \\
(0.167)\end{array}$ & $\begin{array}{c}-0.238 \\
(0.179)\end{array}$ \\
\hline Installation and other metal prof. & $\begin{array}{l}0.224^{*} \\
(0.116)\end{array}$ & $\begin{array}{c}0.143 \\
(0.128)\end{array}$ & $\begin{array}{c}0.180 \\
(0.185)\end{array}$ & $\begin{array}{c}0.149 \\
(0.180)\end{array}$ & $\begin{array}{c}-0.224 \\
(0.204)\end{array}$ \\
\hline Textil manufacturing and processing & $\begin{array}{c}0.045 \\
(0.161)\end{array}$ & $\begin{array}{c}-0.450^{* *} \\
(0.196)\end{array}$ & $\begin{array}{c}0.246 \\
(0.246)\end{array}$ & $\begin{array}{c}-0.011 \\
(0.234)\end{array}$ & $\begin{array}{c}-0.495 \\
(0.316)\end{array}$ \\
\hline Leather manufacturing/ processing & $\begin{array}{c}0.251 \\
(0.201)\end{array}$ & $\begin{array}{l}0.363^{*} \\
(0.186)\end{array}$ & $\begin{array}{c}0.070 \\
(0.248)\end{array}$ & $\begin{array}{c}0.212 \\
(0.439)\end{array}$ & $\begin{array}{c}0.092 \\
(0.276)\end{array}$ \\
\hline Food manufacturing and processing & $\begin{array}{c}0.021 \\
(0.102)\end{array}$ & $\begin{array}{c}-0.196 \\
(0.121)\end{array}$ & $\begin{array}{l}0.227^{*} \\
(0.134)\end{array}$ & $\begin{array}{l}-0.196 \\
(0.163)\end{array}$ & $\begin{array}{c}-0.122 \\
(0.167)\end{array}$ \\
\hline Structural and civil engineering & $\begin{array}{l}-0.081 \\
(0.113)\end{array}$ & $\begin{array}{c}-0.181 \\
(0.127)\end{array}$ & $\begin{array}{l}-0.038 \\
(0.156)\end{array}$ & $\begin{array}{c}-0.177 \\
(0.169)\end{array}$ & $\begin{array}{c}-0.286 \\
(0.195)\end{array}$ \\
\hline Extension building professions and interior decorators & $\begin{array}{c}0.019 \\
(0.127)\end{array}$ & $\begin{array}{l}-0.058 \\
(0.145)\end{array}$ & $\begin{array}{c}0.156 \\
(0.167)\end{array}$ & $\begin{array}{c}0.033 \\
(0.193)\end{array}$ & $\begin{array}{l}-0.114 \\
(0.217)\end{array}$ \\
\hline Wood and synthetic materials processing & $\begin{array}{c}0.078 \\
(0.126)\end{array}$ & $\begin{array}{l}-0.122 \\
(0.146)\end{array}$ & $\begin{array}{c}0.220 \\
(0.169)\end{array}$ & $\begin{array}{c}0.044 \\
(0.192)\end{array}$ & $\begin{array}{c}-0.469^{* *} \\
(0.215)\end{array}$ \\
\hline Painters, varnishers and related & $\begin{array}{c}0.124 \\
(0.174)\end{array}$ & $\begin{array}{c}-0.062 \\
(0.225)\end{array}$ & $\begin{array}{c}0.088 \\
(0.226)\end{array}$ & $\begin{array}{l}-0.217 \\
(0.256)\end{array}$ & $\begin{array}{c}-0.442 \\
(0.307)\end{array}$ \\
\hline Goods inspectors, dispatch workers & $\begin{array}{l}0.209^{*} \\
(0.114)\end{array}$ & $\begin{array}{c}-0.076 \\
(0.135)\end{array}$ & $\begin{array}{c}0.226 \\
(0.141)\end{array}$ & $\begin{array}{c}0.047 \\
(0.167)\end{array}$ & $\begin{array}{l}-0.217 \\
(0.203)\end{array}$ \\
\hline Unskilled workers & $\begin{array}{c}0.047 \\
(0.129)\end{array}$ & $\begin{array}{c}-0.283^{*} \\
(0.148)\end{array}$ & $\begin{array}{c}-0.014 \\
(0.176)\end{array}$ & $\begin{array}{c}-0.186 \\
(0.169)\end{array}$ & $\begin{array}{c}-0.594^{* * *} \\
(0.219)\end{array}$ \\
\hline Machine, plant operators and machine setters & $\begin{array}{c}0.186 \\
(0.113)\end{array}$ & $\begin{array}{c}-0.024 \\
(0.142)\end{array}$ & $\begin{array}{c}0.323^{* *} \\
(0.144)\end{array}$ & $\begin{array}{l}-0.068 \\
(0.173)\end{array}$ & $\begin{array}{c}0.046 \\
(0.181)\end{array}$ \\
\hline Engineers, chemists, physicists, mathematicians & $\begin{array}{c}0.228^{* *} \\
(0.097)\end{array}$ & $\begin{array}{c}0.095 \\
(0.109)\end{array}$ & $\begin{array}{c}0.124 \\
(0.123)\end{array}$ & $\begin{array}{l}-0.029 \\
(0.147)\end{array}$ & $\begin{array}{l}0.297^{*} \\
(0.158)\end{array}$ \\
\hline Technicians and technical specialists & $\begin{array}{c}0.221^{* *} \\
(0.096)\end{array}$ & $\begin{array}{c}0.083 \\
(0.110)\end{array}$ & $\begin{array}{c}0.196 \\
(0.121)\end{array}$ & $\begin{array}{c}0.160 \\
(0.145)\end{array}$ & $\begin{array}{c}0.137 \\
(0.160)\end{array}$ \\
\hline Sales staff & $\begin{array}{l}0.153^{*} \\
(0.093)\end{array}$ & $\begin{array}{c}0.053 \\
(0.104)\end{array}$ & $\begin{array}{c}0.177 \\
(0.118)\end{array}$ & $\begin{array}{c}-0.055 \\
(0.144)\end{array}$ & $\begin{array}{c}0.087 \\
(0.155)\end{array}$ \\
\hline Bank/building society/insurance specialists & $\begin{array}{c}0.246^{* *} \\
(0.097)\end{array}$ & $\begin{array}{c}0.112 \\
(0.108)\end{array}$ & $\begin{array}{l}0.226^{*} \\
(0.123)\end{array}$ & $\begin{array}{c}0.187 \\
(0.148)\end{array}$ & $\begin{array}{c}0.368^{* *} \\
(0.161)\end{array}$ \\
\hline Transport prof. & $\begin{array}{c}0.103 \\
(0.096)\end{array}$ & $\begin{array}{l}-0.037 \\
(0.108)\end{array}$ & $\begin{array}{c}0.164 \\
(0.122)\end{array}$ & $\begin{array}{l}-0.071 \\
(0.144)\end{array}$ & $\begin{array}{l}-0.253 \\
(0.157)\end{array}$ \\
\hline Management, consultancy, administration, other office prof. & $\begin{array}{c}0.243^{* * *} \\
(0.089)\end{array}$ & $\begin{array}{l}0.192^{*} \\
(0.098)\end{array}$ & $\begin{array}{c}0.159 \\
(0.113)\end{array}$ & $\begin{array}{c}0.077 \\
(0.137)\end{array}$ & $\begin{array}{c}0.487^{* * *} \\
(0.147)\end{array}$ \\
\hline Guard/Security services and law and enforcement & $\begin{array}{c}0.261^{* * * *} \\
(0.098)\end{array}$ & $\begin{array}{c}0.221^{* *} \\
(0.111)\end{array}$ & $\begin{array}{c}0.254^{* *} \\
(0.126)\end{array}$ & $\begin{array}{c}0.149 \\
(0.150)\end{array}$ & $\begin{array}{c}0.343^{* *} \\
(0.155)\end{array}$ \\
\hline Journalism, translation, artistic and related & $\begin{array}{c}0.274^{* *} \\
(0.107)\end{array}$ & $\begin{array}{c}0.058 \\
(0.119)\end{array}$ & $\begin{array}{c}0.195 \\
(0.137)\end{array}$ & $\begin{array}{l}0.299^{*} \\
(0.159)\end{array}$ & $\begin{array}{l}-0.054 \\
(0.180)\end{array}$ \\
\hline Health care professions & $\begin{array}{c}0.201^{* *} \\
(0.096)\end{array}$ & $\begin{array}{c}0.093 \\
(0.106)\end{array}$ & $\begin{array}{c}0.183 \\
(0.120)\end{array}$ & $\begin{array}{l}-0.053 \\
(0.145)\end{array}$ & $\begin{array}{c}0.214 \\
(0.157)\end{array}$ \\
\hline Social welfare and teaching & $\begin{array}{c}0.264^{* * *} \\
(0.094)\end{array}$ & $\begin{array}{c}0.231^{* *} \\
(0.104)\end{array}$ & $\begin{array}{c}0.244^{* *} \\
(0.119)\end{array}$ & $\begin{array}{c}0.041 \\
(0.141)\end{array}$ & $\begin{array}{c}0.358^{* *} \\
(0.152)\end{array}$ \\
\hline Arts and natural science & $\begin{array}{c}0.334^{* * *} \\
(0.114)\end{array}$ & $\begin{array}{c}0.275^{* *} \\
(0.125)\end{array}$ & $\begin{array}{c}0.372^{* * *} \\
(0.143)\end{array}$ & $\begin{array}{c}0.224 \\
(0.170)\end{array}$ & $\begin{array}{c}0.464^{* * *} \\
(0.178)\end{array}$ \\
\hline Other service prof. & $\begin{array}{c}0.127 \\
(0.094)\end{array}$ & $\begin{array}{l}-0.156 \\
(0.106)\end{array}$ & $\begin{array}{l}0.221^{*} \\
(0.120)\end{array}$ & $\begin{array}{l}-0.176 \\
(0.144)\end{array}$ & $\begin{array}{l}-0.069 \\
(0.158)\end{array}$ \\
\hline \multicolumn{6}{|l|}{ Industry (Ref.: Agriculture) } \\
\hline Mining, quarrying, energy, water & $\begin{array}{c}0.039 \\
(0.108)\end{array}$ & $\begin{array}{c}-0.082 \\
(0.129)\end{array}$ & $\begin{array}{l}-0.139 \\
(0.123)\end{array}$ & $\begin{array}{c}0.389^{* *} \\
(0.156)\end{array}$ & $\begin{array}{c}0.654^{* * *} \\
(0.180)\end{array}$ \\
\hline Manufacturing & $\begin{array}{c}0.059 \\
(0.088)\end{array}$ & $\begin{array}{l}-0.081 \\
(0.102)\end{array}$ & $\begin{array}{c}-0.018 \\
(0.099)\end{array}$ & $\begin{array}{l}0.226^{*} \\
(0.132)\end{array}$ & $\begin{array}{c}0.578^{* * *} \\
(0.160)\end{array}$ \\
\hline Chemicals/pulp/paper & $\begin{array}{c}0.090 \\
(0.094)\end{array}$ & $\begin{array}{c}-0.027 \\
(0.110)\end{array}$ & $\begin{array}{l}-0.062 \\
(0.110)\end{array}$ & $\begin{array}{c}0.214 \\
(0.143)\end{array}$ & $\begin{array}{c}0.642^{* * *} \\
(0.171)\end{array}$ \\
\hline Construction & $\begin{array}{c}0.073 \\
(0.092)\end{array}$ & $\begin{array}{l}-0.176 \\
(0.107)\end{array}$ & $\begin{array}{l}-0.043 \\
(0.106)\end{array}$ & $\begin{array}{c}0.214 \\
(0.140)\end{array}$ & $\begin{array}{c}0.526^{* * *} \\
(0.167)\end{array}$ \\
\hline Iron/steel & $\begin{array}{l}-0.011 \\
(0.094)\end{array}$ & $\begin{array}{c}-0.241^{* *} \\
(0.112)\end{array}$ & $\begin{array}{c}-0.031 \\
(0.108)\end{array}$ & $\begin{array}{c}0.225 \\
(0.140)\end{array}$ & $\begin{array}{c}0.531^{* * *} \\
(0.171)\end{array}$ \\
\hline Textile/apparel & $\begin{array}{c}0.203 \\
(0.130)\end{array}$ & $\begin{array}{c}0.123 \\
(0.141)\end{array}$ & $\begin{array}{l}-0.099 \\
(0.185)\end{array}$ & $\begin{array}{c}0.403^{* *} \\
(0.185)\end{array}$ & $\begin{array}{c}0.526^{* *} \\
(0.224)\end{array}$ \\
\hline Wholesale/retail & $\begin{array}{l}-0.033 \\
(0.088)\end{array}$ & $\begin{array}{c}-0.241^{* *} \\
(0.103)\end{array}$ & $\begin{array}{l}-0.068 \\
(0.099)\end{array}$ & $\begin{array}{c}0.096 \\
(0.135)\end{array}$ & $\begin{array}{c}0.168 \\
(0.160)\end{array}$ \\
\hline Transport/communication & $\begin{array}{l}-0.088 \\
(0.094)\end{array}$ & $\begin{array}{c}-0.268^{* *} \\
(0.111)\end{array}$ & $\begin{array}{l}-0.078 \\
(0.109)\end{array}$ & $\begin{array}{c}0.081 \\
(0.141)\end{array}$ & $\begin{array}{c}0.400^{* *} \\
(0.167)\end{array}$ \\
\hline Public service & $\begin{array}{c}0.004 \\
(0.087)\end{array}$ & $\begin{array}{c}-0.046 \\
(0.101)\end{array}$ & $\begin{array}{l}-0.081 \\
(0.098)\end{array}$ & $\begin{array}{c}0.276^{* *} \\
(0.130)\end{array}$ & $\begin{array}{c}0.356^{* *} \\
(0.158)\end{array}$ \\
\hline Financial/private services & $\begin{array}{c}-0.005 \\
(0.087)\end{array}$ & $\begin{array}{c}-0.187^{*} \\
(0.101)\end{array}$ & $\begin{array}{l}-0.093 \\
(0.098)\end{array}$ & $\begin{array}{c}0.099 \\
(0.133)\end{array}$ & $\begin{array}{l}0.288^{*} \\
(0.159)\end{array}$ \\
\hline
\end{tabular}


Table S.5: Full Estimation Results - Conditional OLS (ctd.)

\begin{tabular}{|c|c|c|c|c|c|}
\hline & Life & Work & Family & Leisure & Income \\
\hline Not categorized & $\begin{array}{c}0.057 \\
(0.094)\end{array}$ & $\begin{array}{c}0.082 \\
(0.109)\end{array}$ & $\begin{array}{l}-0.003 \\
(0.109)\end{array}$ & $\begin{array}{c}0.363^{* * *} \\
(0.140)\end{array}$ & $\begin{array}{c}0.347^{* *} \\
(0.170)\end{array}$ \\
\hline Constant & $\begin{array}{c}7.575^{* * *} \\
(0.138)\end{array}$ & $\begin{array}{c}7.599^{* * *} \\
(0.148)\end{array}$ & $\begin{array}{c}8.947^{* * *} \\
(0.166)\end{array}$ & $\begin{array}{c}7.572^{* * *} \\
(0.211)\end{array}$ & $\begin{array}{c}4.598^{* * *} \\
(0.211)\end{array}$ \\
\hline $\mathrm{N}$ & 122456 & 122456 & 68782 & 111288 & 78016 \\
\hline Year FE & $\checkmark$ & $\checkmark$ & $\checkmark$ & $\checkmark$ & $\checkmark$ \\
\hline
\end{tabular}

Note: Clustered standard errors in parentheses. ${ }^{2} p<0.1,{ }^{* *} p<0.05,{ }^{* * *} p<0.01$.

Table S.6: Full estimation results - Instrumental variables

\begin{tabular}{|c|c|c|c|c|c|c|c|c|c|c|}
\hline & \multicolumn{2}{|c|}{ Life } & \multicolumn{2}{|c|}{ Work } & \multicolumn{2}{|c|}{ Family } & \multicolumn{2}{|c|}{ Leisure } & \multicolumn{2}{|c|}{ Income } \\
\hline & IV1 & IV2 & IV1 & IV2 & IV1 & IV2 & IV1 & IV2 & IV1 & IV2 \\
\hline Work-linked & $\begin{array}{c}0.397^{* * *} \\
(0.115)\end{array}$ & $\begin{array}{c}0.441^{* * *} \\
(0.098)\end{array}$ & $\begin{array}{c}0.412^{* * *} \\
(0.125)\end{array}$ & $\begin{array}{c}0.408^{* * *} \\
(0.131)\end{array}$ & $\begin{array}{c}0.221 \\
(0.136)\end{array}$ & $\begin{array}{c}0.279^{* *} \\
(0.114)\end{array}$ & $\begin{array}{c}0.003 \\
(0.239)\end{array}$ & $\begin{array}{c}0.026 \\
(0.256)\end{array}$ & $\begin{array}{c}0.847^{* * *} \\
(0.189)\end{array}$ & $\begin{array}{c}0.792^{* * *} \\
(0.212)\end{array}$ \\
\hline \multicolumn{11}{|l|}{ Individual characteristics } \\
\hline Female & $\begin{array}{c}0.010 \\
(0.023)\end{array}$ & $\begin{array}{c}0.013 \\
(0.022)\end{array}$ & $\begin{array}{c}0.021 \\
(0.028)\end{array}$ & $\begin{array}{c}0.033 \\
(0.029)\end{array}$ & $\begin{array}{c}-0.136^{* * *} \\
(0.031)\end{array}$ & $\begin{array}{c}-0.137^{* * *} \\
(0.027)\end{array}$ & $\begin{array}{c}-0.284^{* * *} \\
(0.036)\end{array}$ & $\begin{array}{c}-0.255^{* * *} \\
(0.034)\end{array}$ & $\begin{array}{c}-0.089^{* *} \\
(0.039)\end{array}$ & $\begin{array}{c}-0.105^{* * *} \\
(0.037)\end{array}$ \\
\hline \multicolumn{11}{|l|}{ Age (Ref.: 25-34 years) } \\
\hline $35-44$ years & $\begin{array}{c}-0.123^{* * *} \\
(0.017)\end{array}$ & $\begin{array}{c}-0.131^{* * *} \\
(0.023)\end{array}$ & $\begin{array}{l}-0.007 \\
(0.021)\end{array}$ & $\begin{array}{l}-0.007 \\
(0.028)\end{array}$ & $\begin{array}{c}-0.199^{* * *} \\
(0.025)\end{array}$ & $\begin{array}{c}-0.192^{* * *} \\
(0.033)\end{array}$ & $\begin{array}{c}-0.045^{*} \\
(0.025)\end{array}$ & $\begin{array}{l}-0.043 \\
(0.035)\end{array}$ & $\begin{array}{c}0.006 \\
(0.035)\end{array}$ & $\begin{array}{l}-0.001 \\
(0.039)\end{array}$ \\
\hline $45-54$ years & $\begin{array}{c}-0.234^{* * *} \\
(0.022)\end{array}$ & $\begin{array}{c}-0.249^{* * *} \\
(0.032)\end{array}$ & $\begin{array}{c}-0.068^{* *} \\
(0.028)\end{array}$ & $\begin{array}{c}-0.071^{*} \\
(0.037)\end{array}$ & $\begin{array}{c}-0.331^{* * *} \\
(0.032)\end{array}$ & $\begin{array}{c}-0.342^{* * *} \\
(0.042)\end{array}$ & $\begin{array}{c}-0.077^{* * *} \\
(0.029)\end{array}$ & $\begin{array}{c}-0.078^{*} \\
(0.047)\end{array}$ & $\begin{array}{c}-0.141^{* * *} \\
(0.045)\end{array}$ & $\begin{array}{c}-0.137^{* * *} \\
(0.050)\end{array}$ \\
\hline $55-64$ years & $\begin{array}{c}-0.226^{* * *} \\
(0.034)\end{array}$ & $\begin{array}{c}-0.238^{* * *} \\
(0.046)\end{array}$ & $\begin{array}{l}-0.021 \\
(0.041)\end{array}$ & $\begin{array}{l}-0.008 \\
(0.054)\end{array}$ & $\begin{array}{c}-0.262^{* * *} \\
(0.046)\end{array}$ & $\begin{array}{c}-0.265^{* * *} \\
(0.059)\end{array}$ & $\begin{array}{l}-0.045 \\
(0.044)\end{array}$ & $\begin{array}{l}-0.069 \\
(0.064)\end{array}$ & $\begin{array}{c}-0.142^{* *} \\
(0.058)\end{array}$ & $\begin{array}{c}-0.121^{*} \\
(0.069)\end{array}$ \\
\hline \multicolumn{11}{|l|}{ Regional characteristics } \\
\hline Rural Area & $\begin{array}{l}-0.011 \\
(0.020)\end{array}$ & $\begin{array}{c}-0.116^{* * *} \\
(0.027)\end{array}$ & $\begin{array}{c}0.000 \\
(0.026)\end{array}$ & $\begin{array}{l}-0.030 \\
(0.030)\end{array}$ & $\begin{array}{c}0.012 \\
(0.024)\end{array}$ & $\begin{array}{c}0.010 \\
(0.033)\end{array}$ & $\begin{array}{c}-0.003 \\
(0.028)\end{array}$ & $\begin{array}{c}-0.099^{* *} \\
(0.039)\end{array}$ & $\begin{array}{l}-0.020 \\
(0.032)\end{array}$ & $\begin{array}{c}-0.096^{* *} \\
(0.038)\end{array}$ \\
\hline \multicolumn{11}{|l|}{ Federal state (Ref.: Schleswig-Holstein) } \\
\hline Hamburg & $\begin{array}{c}-0.169^{* *} \\
(0.071)\end{array}$ & & $\begin{array}{c}-0.171^{*} \\
(0.098)\end{array}$ & & $\begin{array}{l}-0.002 \\
(0.082)\end{array}$ & & $\begin{array}{l}-0.052 \\
(0.114)\end{array}$ & & $\begin{array}{l}-0.032 \\
(0.117)\end{array}$ & \\
\hline Lower Saxony & $\begin{array}{c}-0.292^{* * *} \\
(0.051)\end{array}$ & & $\begin{array}{c}-0.122^{*} \\
(0.064)\end{array}$ & & $\begin{array}{c}-0.311^{* * *} \\
(0.064)\end{array}$ & & $\begin{array}{c}-0.288^{* * *} \\
(0.079)\end{array}$ & & $\begin{array}{l}-0.092 \\
(0.076)\end{array}$ & \\
\hline Bremen & $\begin{array}{c}-0.342^{* * *} \\
(0.112)\end{array}$ & & $\begin{array}{l}-0.205 \\
(0.134)\end{array}$ & & $\begin{array}{c}0.385^{* * *} \\
(0.110)\end{array}$ & & $\begin{array}{c}-0.407^{* * *} \\
(0.137)\end{array}$ & & $\begin{array}{c}0.030 \\
(0.164)\end{array}$ & \\
\hline North Rhine-Westphalia & $\begin{array}{c}-0.336^{* * *} \\
(0.045)\end{array}$ & & $\begin{array}{c}-0.212^{* * *} \\
(0.062)\end{array}$ & & $\begin{array}{c}-0.248^{* * *} \\
(0.058)\end{array}$ & & $\begin{array}{c}-0.384^{* * *} \\
(0.077)\end{array}$ & & $\begin{array}{c}-0.151^{* *} \\
(0.074)\end{array}$ & \\
\hline Hesse & $\begin{array}{c}-0.375^{* * *} \\
(0.053)\end{array}$ & & $\begin{array}{c}-0.282^{* * *} \\
(0.071)\end{array}$ & & $\begin{array}{c}-0.426^{* * *} \\
(0.069)\end{array}$ & & $\begin{array}{c}-0.491^{* * *} \\
(0.089)\end{array}$ & & $\begin{array}{c}-0.291^{* * *} \\
(0.080)\end{array}$ & \\
\hline Rhinel.-Palatinate & $\begin{array}{c}-0.159^{* * *} \\
(0.057)\end{array}$ & & $\begin{array}{c}0.090 \\
(0.066)\end{array}$ & & $\begin{array}{c}-0.190^{* * *} \\
(0.069)\end{array}$ & & $\begin{array}{c}-0.393^{* * *} \\
(0.086)\end{array}$ & & $\begin{array}{c}0.131 \\
(0.083)\end{array}$ & \\
\hline Baden-Wuerttemberg & $\begin{array}{c}-0.302^{* * *} \\
(0.046)\end{array}$ & & $\begin{array}{c}-0.210^{* * *} \\
(0.066)\end{array}$ & & $\begin{array}{c}-0.339^{* * *} \\
(0.061)\end{array}$ & & $\begin{array}{c}-0.568^{* * *} \\
(0.082)\end{array}$ & & $\begin{array}{c}-0.187^{* *} \\
(0.076)\end{array}$ & \\
\hline Bavaria & $\begin{array}{c}-0.344^{* * *} \\
(0.049)\end{array}$ & & $\begin{array}{c}-0.179^{* * *} \\
(0.066)\end{array}$ & & $\begin{array}{c}-0.320^{* * *} \\
(0.057)\end{array}$ & & $\begin{array}{c}-0.255^{* * *} \\
(0.084)\end{array}$ & & $\begin{array}{l}-0.119 \\
(0.074)\end{array}$ & \\
\hline Saarland & $\begin{array}{c}-0.382^{* * *} \\
(0.098)\end{array}$ & & $\begin{array}{c}-0.318^{* *} \\
(0.140)\end{array}$ & & $\begin{array}{c}-0.373^{* *} \\
(0.156)\end{array}$ & & $\begin{array}{c}-0.393^{* *} \\
(0.159)\end{array}$ & & $\begin{array}{c}-0.283^{*} \\
(0.153)\end{array}$ & \\
\hline Berlin & $\begin{array}{c}-0.601^{* * *} \\
(0.060)\end{array}$ & & $\begin{array}{c}-0.557^{* * *} \\
(0.078)\end{array}$ & & $\begin{array}{c}-0.533^{* * *} \\
(0.083)\end{array}$ & & $\begin{array}{c}-0.476^{* * *} \\
(0.099)\end{array}$ & & $\begin{array}{c}-0.597^{* * *} \\
(0.097)\end{array}$ & \\
\hline Brandenburg & $\begin{array}{c}-0.745^{* * *} \\
(0.053)\end{array}$ & & $\begin{array}{c}-0.444^{* * *} \\
(0.074)\end{array}$ & & $\begin{array}{c}-0.393^{* * *} \\
(0.066)\end{array}$ & & $\begin{array}{c}-0.673^{* * *} \\
(0.095)\end{array}$ & & $\begin{array}{c}-0.508^{* * *} \\
(0.091)\end{array}$ & \\
\hline Mecklenburg-Western Pomerania & $\begin{array}{c}-0.521^{* * *} \\
(0.070)\end{array}$ & & $\begin{array}{c}-0.228^{* *} \\
(0.090)\end{array}$ & & $\begin{array}{l}-0.145 \\
(0.089)\end{array}$ & & $\begin{array}{c}-0.408^{* * *} \\
(0.090)\end{array}$ & & $\begin{array}{l}-0.171 \\
(0.107)\end{array}$ & \\
\hline Saxony & $\begin{array}{c}-0.588^{* * *} \\
(0.052)\end{array}$ & & $\begin{array}{c}-0.168^{* *} \\
(0.069)\end{array}$ & & $\begin{array}{c}-0.320^{* * *} \\
(0.066)\end{array}$ & & $\begin{array}{c}-0.578^{* * *} \\
(0.095)\end{array}$ & & $\begin{array}{c}-0.457^{* * *} \\
(0.079)\end{array}$ & \\
\hline Saxony-Anhalt & $\begin{array}{c}-0.754^{* * *} \\
(0.061)\end{array}$ & & $\begin{array}{c}-0.383^{* * *} \\
(0.076)\end{array}$ & & $\begin{array}{c}-0.327^{* * *} \\
(0.084)\end{array}$ & & $\begin{array}{c}-0.774^{* * *} \\
(0.090)\end{array}$ & & $\begin{array}{c}-0.532^{* * *} \\
(0.092)\end{array}$ & \\
\hline Thuringia & $\begin{array}{c}-0.678^{* * *} \\
(0.051)\end{array}$ & & $\begin{array}{c}-0.544^{* * *} \\
(0.071)\end{array}$ & & $\begin{array}{c}-0.346^{* * *} \\
(0.065)\end{array}$ & & $\begin{array}{c}-0.815^{* * *} \\
(0.095)\end{array}$ & & $\begin{array}{c}-0.691^{* * *} \\
(0.090)\end{array}$ & \\
\hline Years of education & $\begin{array}{c}0.017^{* * * *} \\
(0.005)\end{array}$ & $\begin{array}{c}0.010^{* *} \\
(0.004)\end{array}$ & $\begin{array}{c}0.002 \\
(0.006)\end{array}$ & $\begin{array}{l}-0.004 \\
(0.006)\end{array}$ & $\begin{array}{c}-0.018^{* * *} \\
(0.005)\end{array}$ & $\begin{array}{c}-0.016^{* * *} \\
(0.006)\end{array}$ & $\begin{array}{c}-0.015^{* *} \\
(0.006)\end{array}$ & $\begin{array}{c}-0.019^{* * *} \\
(0.007)\end{array}$ & $\begin{array}{c}0.074^{* * *} \\
(0.009)\end{array}$ & $\begin{array}{c}0.066^{* * *} \\
(0.007)\end{array}$ \\
\hline \multicolumn{11}{|l|}{ Household characteristics } \\
\hline Married & $\begin{array}{c}0.126^{* * *} \\
(0.024)\end{array}$ & $\begin{array}{c}0.155^{* * *} \\
(0.035)\end{array}$ & $\begin{array}{c}0.103^{* * *} \\
(0.025)\end{array}$ & $\begin{array}{c}0.117^{* * *} \\
(0.038)\end{array}$ & $\begin{array}{c}0.302^{* * *} \\
(0.029)\end{array}$ & $\begin{array}{c}0.332^{* * *} \\
(0.045)\end{array}$ & $\begin{array}{l}-0.023 \\
(0.036)\end{array}$ & $\begin{array}{c}-0.034 \\
(0.046)\end{array}$ & $\begin{array}{r}0.072^{* *} \\
(0.036)\end{array}$ & $\begin{array}{c}0.102^{* *} \\
(0.049)\end{array}$ \\
\hline Number of children in $\mathrm{HH}$ & $\begin{array}{c}0.007 \\
(0.009)\end{array}$ & $\begin{array}{c}0.006 \\
(0.012)\end{array}$ & $\begin{array}{c}0.045^{* * *} \\
(0.009)\end{array}$ & $\begin{array}{c}0.043^{* * *} \\
(0.013)\end{array}$ & $\begin{array}{c}-0.037^{* * *} \\
(0.011)\end{array}$ & $\begin{array}{c}-0.043^{* *} \\
(0.017)\end{array}$ & $\begin{array}{c}-0.208^{* * *} \\
(0.012)\end{array}$ & $\begin{array}{c}-0.203^{* * *} \\
(0.017)\end{array}$ & $\begin{array}{c}-0.034^{* *} \\
(0.015)\end{array}$ & $\begin{array}{l}-0.028 \\
(0.017)\end{array}$ \\
\hline Parntership length & $\begin{array}{c}-0.026^{* * *} \\
(0.001)\end{array}$ & $\begin{array}{c}-0.029^{* * *} \\
(0.002)\end{array}$ & $\begin{array}{c}-0.014^{* * *} \\
(0.002)\end{array}$ & $\begin{array}{c}-0.015^{* * *} \\
(0.002)\end{array}$ & $\begin{array}{c}-0.021^{* * *} \\
(0.002)\end{array}$ & $\begin{array}{c}-0.023^{* * *} \\
(0.003)\end{array}$ & $\begin{array}{c}-0.008^{* * *} \\
(0.002)\end{array}$ & $\begin{array}{c}-0.008^{* * *} \\
(0.003)\end{array}$ & $\begin{array}{c}-0.011^{* * *} \\
(0.002)\end{array}$ & $\begin{array}{c}-0.014^{* * *} \\
(0.003)\end{array}$ \\
\hline Censored partnership length & $\begin{array}{c}0.002 \\
(0.018)\end{array}$ & $\begin{array}{l}-0.030 \\
(0.031)\end{array}$ & $\begin{array}{c}0.059^{* * *} \\
(0.022)\end{array}$ & $\begin{array}{c}0.032 \\
(0.035)\end{array}$ & $\begin{array}{l}0.044^{*} \\
(0.024)\end{array}$ & $\begin{array}{c}0.029 \\
(0.039)\end{array}$ & $\begin{array}{c}0.014 \\
(0.029)\end{array}$ & $\begin{array}{l}-0.002 \\
(0.043)\end{array}$ & $\begin{array}{c}0.084^{* * *} \\
(0.030)\end{array}$ & $\begin{array}{c}0.069 \\
(0.044)\end{array}$ \\
\hline Self-employed & $\begin{array}{c}-0.063^{*} \\
(0.036)\end{array}$ & $\begin{array}{c}-0.078^{* *} \\
(0.039)\end{array}$ & $\begin{array}{c}0.250^{* * *} \\
(0.043)\end{array}$ & $\begin{array}{c}0.245^{* * *} \\
(0.049)\end{array}$ & $\begin{array}{c}-0.172^{* * *} \\
(0.049)\end{array}$ & $\begin{array}{c}-0.188^{* * *} \\
(0.053)\end{array}$ & $\begin{array}{c}-1.104^{* * *} \\
(0.090)\end{array}$ & $\begin{array}{c}-1.083^{* * *} \\
(0.067)\end{array}$ & $\begin{array}{c}0.315^{* * *} \\
(0.066)\end{array}$ & $\begin{array}{c}0.261^{* * *} * \\
(0.070)\end{array}$ \\
\hline Tenure (in years) & $\begin{array}{c}0.005^{* * *} \\
(0.001)\end{array}$ & $\begin{array}{c}0.005^{* * *} \\
(0.001)\end{array}$ & $\begin{array}{c}-0.008^{* * *} \\
(0.001)\end{array}$ & $\begin{array}{c}-0.007^{* * *} \\
(0.002)\end{array}$ & $\begin{array}{c}0.002 \\
(0.001)\end{array}$ & $\begin{array}{c}0.002 \\
(0.002)\end{array}$ & $\begin{array}{c}0.011^{* * *} \\
(0.001)\end{array}$ & $\begin{array}{c}0.012^{* * *} \\
(0.002)\end{array}$ & $\begin{array}{c}0.017^{* * *} \\
(0.002)\end{array}$ & $\begin{array}{c}0.017^{* * *} \\
(0.002)\end{array}$ \\
\hline \multicolumn{11}{|c|}{ Firm size (Ref.: small, under 20 employees) } \\
\hline medium (20-199) & $\begin{array}{c}0.028 \\
(0.020)\end{array}$ & $\begin{array}{c}0.018 \\
(0.026)\end{array}$ & $\begin{array}{c}-0.069^{* * *} \\
(0.026)\end{array}$ & $\begin{array}{c}-0.096^{* * *} \\
(0.032)\end{array}$ & $\begin{array}{c}-0.053^{*} \\
(0.030)\end{array}$ & $\begin{array}{l}-0.054 \\
(0.033)\end{array}$ & $\begin{array}{c}0.027 \\
(0.037)\end{array}$ & $\begin{array}{c}0.017 \\
(0.038)\end{array}$ & $\begin{array}{c}0.213^{* * *} \\
(0.036)\end{array}$ & $\begin{array}{c}0.180^{* * *} \\
(0.042)\end{array}$ \\
\hline large (200 and more) & $\begin{array}{c}0.044^{* *} \\
(0.022)\end{array}$ & $\begin{array}{c}0.063^{* *} \\
(0.027)\end{array}$ & $\begin{array}{l}-0.038 \\
(0.028)\end{array}$ & $\begin{array}{c}-0.046 \\
(0.033)\end{array}$ & $\begin{array}{c}-0.055^{*} \\
(0.029)\end{array}$ & $\begin{array}{c}-0.065^{* *} \\
(0.033)\end{array}$ & $\begin{array}{c}0.006 \\
(0.037)\end{array}$ & $\begin{array}{c}0.009 \\
(0.039)\end{array}$ & $\begin{array}{c}0.487^{* * *} \\
(0.038)\end{array}$ & $\begin{array}{c}0.490^{* * *} \\
(0.042)\end{array}$ \\
\hline In trained occupation & $\begin{array}{c}0.100^{* * * *} \\
(0.018)\end{array}$ & $\begin{array}{c}0.098^{* * *} \\
(0.021)\end{array}$ & $\begin{array}{c}0.192^{* * *} \\
(0.022)\end{array}$ & $\begin{array}{c}0.193^{* * *} \\
(0.026)\end{array}$ & $\begin{array}{c}0.035 \\
(0.022)\end{array}$ & $\begin{array}{c}0.038 \\
(0.026)\end{array}$ & $\begin{array}{c}0.004 \\
(0.026)\end{array}$ & $\begin{array}{c}0.002 \\
(0.030)\end{array}$ & $\begin{array}{c}0.259^{* * *} \\
(0.034)\end{array}$ & $\begin{array}{c}0.260^{* * *} \\
(0.033)\end{array}$ \\
\hline Fixed-term contract & $-0.144^{* * *}$ & $-0.153^{* * *}$ & $-0.126^{* * *}$ & $-0.096^{* * *}$ & $-0.074^{* * *}$ & $-0.082^{* *}$ & $-0.167^{* * *}$ & $-0.169^{* * *}$ & $-0.436^{* * *}$ & $-0.450^{* * *}$ \\
\hline
\end{tabular}


Table S.6: Full Estimation Results - Instrumental Variables (ctd.)

\begin{tabular}{|c|c|c|c|c|c|c|c|c|c|c|}
\hline & \multicolumn{2}{|c|}{ Life } & \multicolumn{2}{|c|}{ Work } & \multicolumn{2}{|c|}{ Family } & \multicolumn{2}{|c|}{ Leisure } & \multicolumn{2}{|c|}{ Income } \\
\hline & IV1 & IV2 & IV1 & IV2 & IV1 & IV2 & IV1 & IV2 & IV1 & IV2 \\
\hline Full-time employed & $\begin{array}{c}(0.025) \\
-0.083^{* * *} \\
(0.020)\end{array}$ & $\begin{array}{c}(0.027) \\
-0.119^{* * *} \\
(0.025)\end{array}$ & $\begin{array}{c}(0.032) \\
-0.014 \\
(0.024)\end{array}$ & $\begin{array}{l}(0.035) \\
-0.034 \\
(0.030)\end{array}$ & $\begin{array}{c}(0.028) \\
-0.101^{* * *} \\
(0.026)\end{array}$ & $\begin{array}{c}(0.034) \\
-0.102^{* * *} \\
(0.032)\end{array}$ & $\begin{array}{c}(0.036) \\
-0.565^{* * *} \\
(0.039)\end{array}$ & $\begin{array}{c}(0.040) \\
-0.593^{* * *} \\
(0.036)\end{array}$ & $\begin{array}{c}(0.053) \\
0.334^{* * *} \\
(0.036)\end{array}$ & $\begin{array}{c}(0.046) \\
0.295^{* * *} \\
(0.038)\end{array}$ \\
\hline \multicolumn{11}{|l|}{ Partner characteristics } \\
\hline Years of Education & $\begin{array}{c}0.013^{* * *} \\
(0.003)\end{array}$ & $\begin{array}{l}0.007^{*} \\
(0.004)\end{array}$ & $\begin{array}{c}-0.016^{* * *} \\
(0.004)\end{array}$ & $\begin{array}{c}-0.017^{* * *} \\
(0.005)\end{array}$ & $\begin{array}{c}-0.009^{*} \\
(0.004)\end{array}$ & $\begin{array}{c}-0.011^{* *} \\
(0.005)\end{array}$ & $\begin{array}{c}0.021^{* * *} \\
(0.006)\end{array}$ & $\begin{array}{l}0.011^{*} \\
(0.006)\end{array}$ & $\begin{array}{c}0.019^{* * *} \\
(0.006)\end{array}$ & $\begin{array}{c}0.014^{* *} \\
(0.006)\end{array}$ \\
\hline Tenure & $\begin{array}{c}0.004^{* * *} \\
(0.001)\end{array}$ & $\begin{array}{c}0.005^{* * *} \\
(0.001)\end{array}$ & $\begin{array}{l}-0.001 \\
(0.001)\end{array}$ & $\begin{array}{l}-0.001 \\
(0.001)\end{array}$ & $\begin{array}{c}0.003^{* *} \\
(0.001)\end{array}$ & $\begin{array}{c}0.003^{* *} \\
(0.001)\end{array}$ & $\begin{array}{c}0.009^{* * *} \\
(0.001)\end{array}$ & $\begin{array}{c}0.010^{* * *} \\
(0.002)\end{array}$ & $\begin{array}{c}0.001 \\
(0.002)\end{array}$ & $\begin{array}{c}0.002 \\
(0.002)\end{array}$ \\
\hline In trained occupation & $\begin{array}{c}0.074^{* * *} \\
(0.014)\end{array}$ & $\begin{array}{c}0.089^{* * *} \\
(0.019)\end{array}$ & $\begin{array}{c}0.010 \\
(0.017)\end{array}$ & $\begin{array}{c}0.029 \\
(0.024)\end{array}$ & $\begin{array}{c}0.068^{* * *} \\
(0.021)\end{array}$ & $\begin{array}{c}0.071^{* * *} \\
(0.025)\end{array}$ & $\begin{array}{c}0.015 \\
(0.020)\end{array}$ & $\begin{array}{l}-0.007 \\
(0.029)\end{array}$ & $\begin{array}{c}0.015 \\
(0.024)\end{array}$ & $\begin{array}{c}0.011 \\
(0.031)\end{array}$ \\
\hline Fixed-term contract & $\begin{array}{c}-0.071^{* * *} \\
(0.023)\end{array}$ & $\begin{array}{c}-0.046^{*} \\
(0.026)\end{array}$ & $\begin{array}{c}-0.044 \\
(0.030)\end{array}$ & $\begin{array}{l}-0.036 \\
(0.034)\end{array}$ & $\begin{array}{c}-0.053^{*} \\
(0.029)\end{array}$ & $\begin{array}{l}-0.039 \\
(0.035)\end{array}$ & $\begin{array}{l}-0.040 \\
(0.033)\end{array}$ & $\begin{array}{l}-0.042 \\
(0.038)\end{array}$ & $\begin{array}{l}-0.042 \\
(0.036)\end{array}$ & $\begin{array}{l}-0.030 \\
(0.042)\end{array}$ \\
\hline Full-time employed & $\begin{array}{c}-0.031^{*} \\
(0.017)\end{array}$ & $\begin{array}{c}-0.091^{* * *} \\
(0.021)\end{array}$ & $\begin{array}{c}-0.081^{* * *} \\
(0.020)\end{array}$ & $\begin{array}{c}-0.125^{* * *} \\
(0.026)\end{array}$ & $\begin{array}{c}-0.048^{* *} \\
(0.023)\end{array}$ & $\begin{array}{c}-0.058^{* *} \\
(0.027)\end{array}$ & $\begin{array}{c}0.019 \\
(0.028)\end{array}$ & $\begin{array}{l}-0.051 \\
(0.032)\end{array}$ & $\begin{array}{c}-0.194 * * * \\
(0.027)\end{array}$ & $\begin{array}{c}-0.231^{* * *} \\
(0.033)\end{array}$ \\
\hline \multicolumn{11}{|c|}{ Kldb92 occupation (Ref.: Agricultural occupations) } \\
\hline Mining occupations & $\begin{array}{c}-0.148 \\
(0.261)\end{array}$ & $\begin{array}{c}-0.029 \\
(0.291)\end{array}$ & $\begin{array}{c}-0.759^{* * *} \\
(0.211)\end{array}$ & $\begin{array}{c}-0.921^{*} \\
(0.560)\end{array}$ & $\begin{array}{l}-0.010 \\
(0.307)\end{array}$ & $\begin{array}{c}0.048 \\
(0.521)\end{array}$ & $\begin{array}{c}0.467 \\
(0.309)\end{array}$ & $\begin{array}{c}-0.086 \\
(0.460)\end{array}$ & $\begin{array}{l}-0.383 \\
(0.528)\end{array}$ & $\begin{array}{c}-1.258^{*} \\
(0.708)\end{array}$ \\
\hline Stone proc. and construction material manuf. & $\begin{array}{c}0.215 \\
(0.184)\end{array}$ & $\begin{array}{l}-0.121 \\
(0.183)\end{array}$ & $\begin{array}{c}0.063 \\
(0.605)\end{array}$ & $\begin{array}{l}-0.392 \\
(0.511)\end{array}$ & $\begin{array}{c}0.279 \\
(0.265)\end{array}$ & $\begin{array}{c}0.348 \\
(0.250)\end{array}$ & $\begin{array}{c}0.252 \\
(0.167)\end{array}$ & $\begin{array}{c}0.017 \\
(0.349)\end{array}$ & $\begin{array}{c}0.362 \\
(0.235)\end{array}$ & $\begin{array}{c}0.149 \\
(0.464)\end{array}$ \\
\hline Ceramists and glass manufacturing/processing & $\begin{array}{c}0.397^{* *} \\
(0.171)\end{array}$ & $\begin{array}{c}0.399^{* *} \\
(0.203)\end{array}$ & $\begin{array}{c}0.022 \\
(0.314)\end{array}$ & $\begin{array}{c}0.031 \\
(0.313)\end{array}$ & $\begin{array}{c}0.556^{* * *} \\
(0.137)\end{array}$ & $\begin{array}{c}0.661^{* *} \\
(0.299)\end{array}$ & $\begin{array}{c}0.520^{* * *} \\
(0.172)\end{array}$ & $\begin{array}{l}0.623^{*} \\
(0.372)\end{array}$ & $\begin{array}{l}-0.037 \\
(0.421)\end{array}$ & $\begin{array}{l}-0.062 \\
(0.589)\end{array}$ \\
\hline Chemistry and synthetic materials & $\begin{array}{c}0.147 \\
(0.122)\end{array}$ & $\begin{array}{c}0.179 \\
(0.160)\end{array}$ & $\begin{array}{l}-0.064 \\
(0.127)\end{array}$ & $\begin{array}{c}0.094 \\
(0.176)\end{array}$ & $\begin{array}{c}0.372^{* * *} \\
(0.121)\end{array}$ & $\begin{array}{c}0.538^{* * *} \\
(0.179)\end{array}$ & $\begin{array}{c}0.251 \\
(0.174)\end{array}$ & $\begin{array}{l}0.400^{*} \\
(0.220)\end{array}$ & $\begin{array}{c}0.053 \\
(0.207)\end{array}$ & $\begin{array}{c}0.213 \\
(0.237)\end{array}$ \\
\hline Paper manufacturing/processing and print & $\begin{array}{c}0.034 \\
(0.139)\end{array}$ & $\begin{array}{l}-0.032 \\
(0.149)\end{array}$ & $\begin{array}{l}-0.311 \\
(0.198)\end{array}$ & $\begin{array}{l}-0.249 \\
(0.189)\end{array}$ & $\begin{array}{c}0.215 \\
(0.156)\end{array}$ & $\begin{array}{c}0.165 \\
(0.214)\end{array}$ & $\begin{array}{c}0.187 \\
(0.193)\end{array}$ & $\begin{array}{c}0.233 \\
(0.234)\end{array}$ & $\begin{array}{c}-0.421^{* *} \\
(0.210)\end{array}$ & $\begin{array}{l}-0.331 \\
(0.259)\end{array}$ \\
\hline Wood processing, wood/woven goods manufacturing & $\begin{array}{c}0.295^{* * *} \\
(0.108)\end{array}$ & $\begin{array}{l}-0.036 \\
(0.206)\end{array}$ & $\begin{array}{l}-0.172 \\
(0.282)\end{array}$ & $\begin{array}{c}-0.809^{* *} \\
(0.328)\end{array}$ & $\begin{array}{c}0.298^{* *} \\
(0.133)\end{array}$ & $\begin{array}{c}0.398 \\
(0.243)\end{array}$ & $\begin{array}{c}0.651^{* * *} \\
(0.157)\end{array}$ & $\begin{array}{c}0.452 \\
(0.322)\end{array}$ & $\begin{array}{c}-1.065^{* * *} \\
(0.290)\end{array}$ & $\begin{array}{c}-1.377^{* * *} \\
(0.419)\end{array}$ \\
\hline Metal manufacturing and processing & $\begin{array}{l}0.194^{*} \\
(0.114)\end{array}$ & $\begin{array}{c}0.061 \\
(0.143)\end{array}$ & $\begin{array}{c}0.043 \\
(0.128)\end{array}$ & $\begin{array}{l}-0.113 \\
(0.172)\end{array}$ & $\begin{array}{c}0.298^{* *} \\
(0.132)\end{array}$ & $\begin{array}{l}0.330^{*} \\
(0.179)\end{array}$ & $\begin{array}{l}0.258^{*} \\
(0.154)\end{array}$ & $\begin{array}{c}0.221 \\
(0.194)\end{array}$ & $\begin{array}{l}-0.114 \\
(0.190)\end{array}$ & $\begin{array}{c}-0.007 \\
(0.227)\end{array}$ \\
\hline Metal and plant engineering and related & $\begin{array}{c}0.053 \\
(0.100)\end{array}$ & $\begin{array}{l}-0.059 \\
(0.108)\end{array}$ & $\begin{array}{l}-0.107 \\
(0.109)\end{array}$ & $\begin{array}{c}-0.228^{*} \\
(0.121)\end{array}$ & $\begin{array}{l}0.158^{*} \\
(0.092)\end{array}$ & $\begin{array}{c}0.154 \\
(0.134)\end{array}$ & $\begin{array}{l}-0.014 \\
(0.134)\end{array}$ & $\begin{array}{l}-0.129 \\
(0.174)\end{array}$ & $\begin{array}{l}-0.202 \\
(0.151)\end{array}$ & $\begin{array}{l}-0.237 \\
(0.179)\end{array}$ \\
\hline Electrical prof. & $\begin{array}{c}0.153 \\
(0.107)\end{array}$ & $\begin{array}{l}-0.016 \\
(0.123)\end{array}$ & $\begin{array}{c}0.011 \\
(0.119)\end{array}$ & $\begin{array}{l}-0.153 \\
(0.138)\end{array}$ & $\begin{array}{c}0.166 \\
(0.104)\end{array}$ & $\begin{array}{c}0.131 \\
(0.155)\end{array}$ & $\begin{array}{c}0.090 \\
(0.151)\end{array}$ & $\begin{array}{l}-0.049 \\
(0.199)\end{array}$ & $\begin{array}{l}-0.231 \\
(0.157)\end{array}$ & $\begin{array}{l}-0.281 \\
(0.200)\end{array}$ \\
\hline Installation and other metal prof. & $\begin{array}{l}0.231^{*} \\
(0.134)\end{array}$ & $\begin{array}{c}0.130 \\
(0.142)\end{array}$ & $\begin{array}{c}0.150 \\
(0.114)\end{array}$ & $\begin{array}{l}-0.078 \\
(0.161)\end{array}$ & $\begin{array}{c}0.182 \\
(0.136)\end{array}$ & $\begin{array}{c}0.239 \\
(0.220)\end{array}$ & $\begin{array}{c}0.153 \\
(0.211)\end{array}$ & $\begin{array}{c}0.198 \\
(0.219)\end{array}$ & $\begin{array}{l}-0.217 \\
(0.183)\end{array}$ & $\begin{array}{l}-0.185 \\
(0.238)\end{array}$ \\
\hline Textil manufacturing and processing & $\begin{array}{c}0.042 \\
(0.142)\end{array}$ & $\begin{array}{c}0.044 \\
(0.195)\end{array}$ & $\begin{array}{c}-0.453^{* *} \\
(0.196)\end{array}$ & $\begin{array}{l}-0.297 \\
(0.210)\end{array}$ & $\begin{array}{c}0.245 \\
(0.182)\end{array}$ & $\begin{array}{c}0.237 \\
(0.275)\end{array}$ & $\begin{array}{l}-0.013 \\
(0.216)\end{array}$ & $\begin{array}{c}0.134 \\
(0.285)\end{array}$ & $\begin{array}{l}-0.500 \\
(0.322)\end{array}$ & $\begin{array}{l}-0.544 \\
(0.343)\end{array}$ \\
\hline Leather manufacturing/ processing & $\begin{array}{c}0.245 \\
(0.173)\end{array}$ & $\begin{array}{c}0.171 \\
(0.221)\end{array}$ & $\begin{array}{c}0.357^{* *} \\
(0.180)\end{array}$ & $\begin{array}{c}0.251 \\
(0.220)\end{array}$ & $\begin{array}{c}0.066 \\
(0.125)\end{array}$ & $\begin{array}{l}-0.195 \\
(0.282)\end{array}$ & $\begin{array}{c}0.209 \\
(0.431)\end{array}$ & $\begin{array}{l}-0.084 \\
(0.545)\end{array}$ & $\begin{array}{c}0.079 \\
(0.215)\end{array}$ & $\begin{array}{l}-0.070 \\
(0.285)\end{array}$ \\
\hline Food manufacturing and processing & $\begin{array}{c}0.016 \\
(0.104)\end{array}$ & $\begin{array}{l}-0.075 \\
(0.117)\end{array}$ & $\begin{array}{c}-0.202^{*} \\
(0.111)\end{array}$ & $\begin{array}{c}-0.302^{* *} \\
(0.145)\end{array}$ & $\begin{array}{l}0.223^{*} \\
(0.114)\end{array}$ & $\begin{array}{c}0.237 \\
(0.148)\end{array}$ & $\begin{array}{l}-0.199 \\
(0.156)\end{array}$ & $\begin{array}{l}-0.144 \\
(0.191)\end{array}$ & $\begin{array}{l}-0.134 \\
(0.165)\end{array}$ & $\begin{array}{l}-0.130 \\
(0.190)\end{array}$ \\
\hline Structural and civil engineering & $\begin{array}{l}-0.080 \\
(0.110)\end{array}$ & $\begin{array}{c}-0.213^{*} \\
(0.129)\end{array}$ & $\begin{array}{l}-0.180 \\
(0.122)\end{array}$ & $\begin{array}{c}-0.280^{*} \\
(0.146)\end{array}$ & $\begin{array}{c}-0.038 \\
(0.117)\end{array}$ & $\begin{array}{l}-0.004 \\
(0.171)\end{array}$ & $\begin{array}{c}-0.177 \\
(0.142)\end{array}$ & $\begin{array}{l}-0.271 \\
(0.202)\end{array}$ & $\begin{array}{l}-0.287 \\
(0.186)\end{array}$ & $\begin{array}{l}-0.361 \\
(0.222)\end{array}$ \\
\hline Extension building professions and interior decorators & $\begin{array}{c}0.022 \\
(0.112)\end{array}$ & $\begin{array}{l}-0.107 \\
(0.146)\end{array}$ & $\begin{array}{l}-0.056 \\
(0.121)\end{array}$ & $\begin{array}{l}-0.176 \\
(0.165)\end{array}$ & $\begin{array}{c}0.157 \\
(0.155)\end{array}$ & $\begin{array}{c}0.208 \\
(0.181)\end{array}$ & $\begin{array}{c}0.035 \\
(0.155)\end{array}$ & $\begin{array}{l}-0.022 \\
(0.230)\end{array}$ & $\begin{array}{l}-0.112 \\
(0.229)\end{array}$ & $\begin{array}{l}-0.205 \\
(0.243)\end{array}$ \\
\hline Wood and synthetic materials processing & $\begin{array}{c}0.084 \\
(0.108)\end{array}$ & $\begin{array}{l}-0.011 \\
(0.144)\end{array}$ & $\begin{array}{l}-0.115 \\
(0.131)\end{array}$ & $\begin{array}{c}-0.277^{*} \\
(0.160)\end{array}$ & $\begin{array}{c}0.223 \\
(0.139)\end{array}$ & $\begin{array}{l}0.311^{*} \\
(0.177)\end{array}$ & $\begin{array}{c}0.047 \\
(0.144)\end{array}$ & $\begin{array}{l}-0.074 \\
(0.220)\end{array}$ & $\begin{array}{c}-0.460^{* *} \\
(0.208)\end{array}$ & $\begin{array}{c}-0.480^{* *} \\
(0.241)\end{array}$ \\
\hline Painters, varnishers and related & $\begin{array}{c}0.125 \\
(0.130)\end{array}$ & $\begin{array}{c}0.074 \\
(0.212)\end{array}$ & $\begin{array}{l}-0.061 \\
(0.155)\end{array}$ & $\begin{array}{l}-0.170 \\
(0.273)\end{array}$ & $\begin{array}{c}0.090 \\
(0.103)\end{array}$ & $\begin{array}{c}0.037 \\
(0.268)\end{array}$ & $\begin{array}{l}-0.216 \\
(0.196)\end{array}$ & $\begin{array}{l}-0.290 \\
(0.328)\end{array}$ & $\begin{array}{c}-0.441^{*} \\
(0.248)\end{array}$ & $\begin{array}{c}-0.605^{*} \\
(0.351)\end{array}$ \\
\hline Goods inspectors, dispatch workers & $\begin{array}{l}0.208^{*} \\
(0.115)\end{array}$ & $\begin{array}{c}0.143 \\
(0.135)\end{array}$ & $\begin{array}{l}-0.077 \\
(0.137)\end{array}$ & $\begin{array}{l}-0.110 \\
(0.164)\end{array}$ & $\begin{array}{c}0.225^{* *} \\
(0.106)\end{array}$ & $\begin{array}{l}0.266^{*} \\
(0.160)\end{array}$ & $\begin{array}{c}0.046 \\
(0.153)\end{array}$ & $\begin{array}{c}0.248 \\
(0.198)\end{array}$ & $\begin{array}{l}-0.221 \\
(0.194)\end{array}$ & $\begin{array}{l}-0.281 \\
(0.233)\end{array}$ \\
\hline Unskilled workers & $\begin{array}{c}0.047 \\
(0.123)\end{array}$ & $\begin{array}{c}-0.318^{* *} \\
(0.152)\end{array}$ & $\begin{array}{c}-0.283^{* *} \\
(0.135)\end{array}$ & $\begin{array}{c}-0.484^{* * *} \\
(0.172)\end{array}$ & $\begin{array}{l}-0.016 \\
(0.171)\end{array}$ & $\begin{array}{l}-0.082 \\
(0.203)\end{array}$ & $\begin{array}{c}-0.186 \\
(0.158)\end{array}$ & $\begin{array}{c}-0.392^{*} \\
(0.208)\end{array}$ & $\begin{array}{c}-0.599^{* *} \\
(0.249)\end{array}$ & $\begin{array}{c}-0.494^{* *} \\
(0.244)\end{array}$ \\
\hline Machine, plant operators and machine setters & $\begin{array}{c}0.188 \\
(0.124)\end{array}$ & $\begin{array}{c}0.032 \\
(0.133)\end{array}$ & $\begin{array}{l}-0.022 \\
(0.153)\end{array}$ & $\begin{array}{l}-0.097 \\
(0.167)\end{array}$ & $\begin{array}{c}0.323^{* * *} \\
(0.112)\end{array}$ & $\begin{array}{c}0.335^{* *} \\
(0.163)\end{array}$ & $\begin{array}{l}-0.067 \\
(0.199)\end{array}$ & $\begin{array}{l}-0.071 \\
(0.210)\end{array}$ & $\begin{array}{c}0.046 \\
(0.173)\end{array}$ & $\begin{array}{c}0.120 \\
(0.200)\end{array}$ \\
\hline Engineers, Chemists, physicists, mathematicians & $\begin{array}{c}0.232^{* *} \\
(0.101)\end{array}$ & $\begin{array}{c}0.160 \\
(0.107)\end{array}$ & $\begin{array}{c}0.100 \\
(0.112)\end{array}$ & $\begin{array}{l}-0.000 \\
(0.119)\end{array}$ & $\begin{array}{c}0.128 \\
(0.091)\end{array}$ & $\begin{array}{c}0.109 \\
(0.135)\end{array}$ & $\begin{array}{l}-0.027 \\
(0.130)\end{array}$ & $\begin{array}{l}-0.060 \\
(0.173)\end{array}$ & $\begin{array}{c}0.306^{* *} \\
(0.154)\end{array}$ & $\begin{array}{l}0.307^{*} \\
(0.176)\end{array}$ \\
\hline Technicians and technical specialists & $\begin{array}{c}0.222^{* *} \\
(0.100)\end{array}$ & $\begin{array}{c}0.139 \\
(0.107)\end{array}$ & $\begin{array}{c}0.084 \\
(0.111)\end{array}$ & $\begin{array}{l}-0.006 \\
(0.120)\end{array}$ & $\begin{array}{c}0.197^{* *} \\
(0.092)\end{array}$ & $\begin{array}{l}0.225^{*} \\
(0.133)\end{array}$ & $\begin{array}{c}0.161 \\
(0.130)\end{array}$ & $\begin{array}{c}0.103 \\
(0.172)\end{array}$ & $\begin{array}{c}0.138 \\
(0.152)\end{array}$ & $\begin{array}{c}0.129 \\
(0.178)\end{array}$ \\
\hline Sales staff & $\begin{array}{c}0.151 \\
(0.102)\end{array}$ & $\begin{array}{c}0.062 \\
(0.104)\end{array}$ & $\begin{array}{c}0.051 \\
(0.108)\end{array}$ & $\begin{array}{l}-0.012 \\
(0.115)\end{array}$ & $\begin{array}{c}0.176^{* *} \\
(0.087)\end{array}$ & $\begin{array}{l}0.226^{*} \\
(0.129)\end{array}$ & $\begin{array}{c}-0.057 \\
(0.134)\end{array}$ & $\begin{array}{l}-0.048 \\
(0.172)\end{array}$ & $\begin{array}{c}0.082 \\
(0.152)\end{array}$ & $\begin{array}{c}0.100 \\
(0.173)\end{array}$ \\
\hline Bank/building society/insurance specialists & $\begin{array}{c}0.240^{* *} \\
(0.101)\end{array}$ & $\begin{array}{c}0.172 \\
(0.107)\end{array}$ & $\begin{array}{c}0.104 \\
(0.114)\end{array}$ & $\begin{array}{c}0.044 \\
(0.119)\end{array}$ & $\begin{array}{c}0.221^{* *} \\
(0.095)\end{array}$ & $\begin{array}{l}0.261^{*} \\
(0.134)\end{array}$ & $\begin{array}{c}0.184 \\
(0.136)\end{array}$ & $\begin{array}{c}0.163 \\
(0.175)\end{array}$ & $\begin{array}{c}0.353^{* *} \\
(0.159)\end{array}$ & $\begin{array}{c}0.412^{* *} \\
(0.179)\end{array}$ \\
\hline Transport prof. & $\begin{array}{c}0.102 \\
(0.102)\end{array}$ & $\begin{array}{c}0.007 \\
(0.108)\end{array}$ & $\begin{array}{l}-0.039 \\
(0.114)\end{array}$ & $\begin{array}{l}-0.152 \\
(0.120)\end{array}$ & $\begin{array}{l}0.162^{*} \\
(0.093)\end{array}$ & $\begin{array}{c}0.178 \\
(0.135)\end{array}$ & $\begin{array}{l}-0.072 \\
(0.140)\end{array}$ & $\begin{array}{l}-0.099 \\
(0.172)\end{array}$ & $\begin{array}{c}-0.259^{*} \\
(0.157)\end{array}$ & $\begin{array}{c}-0.245 \\
(0.176)\end{array}$ \\
\hline Management, administration, other office prof. & $\begin{array}{c}0.241^{* *} \\
(0.096)\end{array}$ & $\begin{array}{l}0.180^{*} \\
(0.099)\end{array}$ & $\begin{array}{l}0.190^{*} \\
(0.103)\end{array}$ & $\begin{array}{c}0.119 \\
(0.108)\end{array}$ & $\begin{array}{l}0.157^{*} \\
(0.084)\end{array}$ & $\begin{array}{c}0.194 \\
(0.124)\end{array}$ & $\begin{array}{c}0.076 \\
(0.121)\end{array}$ & $\begin{array}{c}0.059 \\
(0.163)\end{array}$ & $\begin{array}{c}0.482^{* * *} \\
(0.143)\end{array}$ & $\begin{array}{c}0.521^{* * *} \\
(0.165)\end{array}$ \\
\hline Guard/Security services and Law and enforcement & $\begin{array}{c}0.255^{* *} \\
(0.103)\end{array}$ & $\begin{array}{c}0.214^{* *} \\
(0.109)\end{array}$ & $\begin{array}{l}0.214^{*} \\
(0.113)\end{array}$ & $\begin{array}{c}0.192 \\
(0.122)\end{array}$ & $\begin{array}{c}0.248^{* *} \\
(0.100)\end{array}$ & $\begin{array}{c}0.322^{* *} \\
(0.138)\end{array}$ & $\begin{array}{c}0.146 \\
(0.150)\end{array}$ & $\begin{array}{c}0.129 \\
(0.176)\end{array}$ & $\begin{array}{c}0.327^{* *} \\
(0.153)\end{array}$ & $\begin{array}{c}0.350^{* *} \\
(0.174)\end{array}$ \\
\hline Journalism, translation, artistic and related & $\begin{array}{c}0.266^{* *} \\
(0.111)\end{array}$ & $\begin{array}{l}0.221^{*} \\
(0.118)\end{array}$ & $\begin{array}{c}0.048 \\
(0.120)\end{array}$ & $\begin{array}{c}-0.028 \\
(0.132)\end{array}$ & $\begin{array}{c}0.188 \\
(0.117)\end{array}$ & $\begin{array}{l}0.264^{*} \\
(0.150)\end{array}$ & $\begin{array}{c}0.294^{* *} \\
(0.145)\end{array}$ & $\begin{array}{c}0.273 \\
(0.186)\end{array}$ & $\begin{array}{l}-0.073 \\
(0.172)\end{array}$ & $\begin{array}{l}-0.045 \\
(0.196)\end{array}$ \\
\hline Health care professions & $\begin{array}{l}0.205^{*} \\
(0.112)\end{array}$ & $\begin{array}{c}0.107 \\
(0.108)\end{array}$ & $\begin{array}{c}0.097 \\
(0.118)\end{array}$ & $\begin{array}{c}0.000 \\
(0.117)\end{array}$ & $\begin{array}{c}0.186^{* *} \\
(0.092)\end{array}$ & $\begin{array}{c}0.198 \\
(0.132)\end{array}$ & $\begin{array}{l}-0.052 \\
(0.147)\end{array}$ & $\begin{array}{l}-0.124 \\
(0.172)\end{array}$ & $\begin{array}{c}0.223 \\
(0.188)\end{array}$ & $\begin{array}{c}0.146 \\
(0.175)\end{array}$ \\
\hline Social welfare and teaching & $\begin{array}{c}0.265^{* *} \\
(0.107)\end{array}$ & $\begin{array}{l}0.201^{*} \\
(0.105)\end{array}$ & $\begin{array}{l}0.232^{*} \\
(0.119)\end{array}$ & $\begin{array}{c}0.163 \\
(0.114)\end{array}$ & $\begin{array}{c}0.245^{* * *} \\
(0.092)\end{array}$ & $\begin{array}{c}0.304^{* *} \\
(0.131)\end{array}$ & $\begin{array}{c}0.042 \\
(0.137)\end{array}$ & $\begin{array}{c}0.036 \\
(0.168)\end{array}$ & $\begin{array}{c}0.360^{* *} \\
(0.166)\end{array}$ & $\begin{array}{c}0.376^{* *} \\
(0.170)\end{array}$ \\
\hline Arts and natural science & $\begin{array}{c}0.330^{* * * *} \\
(0.122)\end{array}$ & $\begin{array}{c}0.282^{* *} \\
(0.126)\end{array}$ & $\begin{array}{c}0.270^{* *} \\
(0.129)\end{array}$ & $\begin{array}{c}0.193 \\
(0.138)\end{array}$ & $\begin{array}{c}0.369^{* * *} \\
(0.129)\end{array}$ & $\begin{array}{c}0.396^{* *} \\
(0.155)\end{array}$ & $\begin{array}{c}0.222 \\
(0.161)\end{array}$ & $\begin{array}{c}0.198 \\
(0.195)\end{array}$ & $\begin{array}{c}0.454^{* *} \\
(0.180)\end{array}$ & $\begin{array}{c}0.528^{* * *} \\
(0.197)\end{array}$ \\
\hline Other service prof. & $\begin{array}{c}0.128 \\
(0.101)\end{array}$ & $\begin{array}{c}0.068 \\
(0.104)\end{array}$ & $\begin{array}{c}-0.156 \\
(0.115)\end{array}$ & $\begin{array}{l}-0.145 \\
(0.117)\end{array}$ & $\begin{array}{c}0.221^{* *} \\
(0.095)\end{array}$ & $\begin{array}{l}0.238^{*} \\
(0.132)\end{array}$ & $\begin{array}{c}-0.176 \\
(0.174)\end{array}$ & $\begin{array}{l}-0.126 \\
(0.171)\end{array}$ & $\begin{array}{c}-0.069 \\
(0.160)\end{array}$ & $\begin{array}{c}-0.054 \\
(0.177)\end{array}$ \\
\hline \multicolumn{11}{|l|}{ Industry (Ref.: Agriculture) } \\
\hline Mining, quarring, energy, water & $\begin{array}{c}0.040 \\
(0.102)\end{array}$ & $\begin{array}{c}0.024 \\
(0.121)\end{array}$ & $\begin{array}{l}-0.081 \\
(0.125)\end{array}$ & $\begin{array}{l}-0.066 \\
(0.138)\end{array}$ & $\begin{array}{l}-0.139 \\
(0.103)\end{array}$ & $\begin{array}{l}-0.183 \\
(0.133)\end{array}$ & $\begin{array}{c}0.389^{* * *} \\
(0.145)\end{array}$ & $\begin{array}{c}0.479^{* * *} \\
(0.178)\end{array}$ & $\begin{array}{c}0.654^{* * *} \\
(0.175)\end{array}$ & $\begin{array}{c}0.526^{* * *} \\
(0.191)\end{array}$ \\
\hline Manufacturing & $\begin{array}{c}0.060 \\
(0.090)\end{array}$ & $\begin{array}{c}0.138 \\
(0.099)\end{array}$ & $\begin{array}{l}-0.079 \\
(0.108)\end{array}$ & $\begin{array}{c}0.005 \\
(0.111)\end{array}$ & $\begin{array}{l}-0.017 \\
(0.085)\end{array}$ & $\begin{array}{c}0.027 \\
(0.106)\end{array}$ & $\begin{array}{l}0.227^{*} \\
(0.126)\end{array}$ & $\begin{array}{c}0.378^{* *} \\
(0.152)\end{array}$ & $\begin{array}{c}0.578^{* * *} \\
(0.164)\end{array}$ & $\begin{array}{c}0.570^{* * *} \\
(0.169)\end{array}$ \\
\hline Chemicals/pulp/paper & 0.090 & 0.167 & -0.028 & 0.028 & -0.064 & 0.012 & 0.213 & $0.320^{*}$ & $0.638^{* * *}$ & $0.623^{* * *}$ \\
\hline
\end{tabular}


Table S.6: Full Estimation Results - Instrumental Variables (ctd.)

\begin{tabular}{|c|c|c|c|c|c|c|c|c|c|c|}
\hline & \multicolumn{2}{|c|}{ Life } & \multicolumn{2}{|c|}{ Work } & \multicolumn{2}{|c|}{ Family } & \multicolumn{2}{|c|}{ Leisure } & \multicolumn{2}{|c|}{ Income } \\
\hline & IV1 & IV2 & IV1 & IV2 & IV1 & IV2 & IV1 & IV2 & IV1 & IV2 \\
\hline & $(0.096)$ & $(0.106)$ & $(0.116)$ & $(0.120)$ & $(0.093)$ & $(0.118)$ & $(0.138)$ & $(0.165)$ & $(0.172)$ & $(0.181)$ \\
\hline Construction & $\begin{array}{c}0.074 \\
(0.093)\end{array}$ & $\begin{array}{c}0.100 \\
(0.104)\end{array}$ & $\begin{array}{l}-0.174 \\
(0.112)\end{array}$ & $\begin{array}{c}-0.120 \\
(0.117)\end{array}$ & $\begin{array}{c}-0.043 \\
(0.095)\end{array}$ & $\begin{array}{c}-0.024 \\
(0.114)\end{array}$ & $\begin{array}{c}0.215 \\
(0.134)\end{array}$ & $\begin{array}{l}0.303^{*} \\
(0.160)\end{array}$ & $\begin{array}{c}0.527^{* * *} \\
(0.171)\end{array}$ & $\begin{array}{c}0.497^{* * *} \\
(0.176)\end{array}$ \\
\hline Iron/steel & $\begin{array}{l}-0.009 \\
(0.095)\end{array}$ & $\begin{array}{c}0.032 \\
(0.107)\end{array}$ & $\begin{array}{c}-0.239^{* *} \\
(0.114)\end{array}$ & $\begin{array}{l}-0.148 \\
(0.123)\end{array}$ & $\begin{array}{l}-0.031 \\
(0.098)\end{array}$ & $\begin{array}{c}0.028 \\
(0.117)\end{array}$ & $\begin{array}{l}0.226^{*} \\
(0.134)\end{array}$ & $\begin{array}{c}0.360^{* *} \\
(0.161)\end{array}$ & $\begin{array}{c}0.531^{* * *} \\
(0.172)\end{array}$ & $\begin{array}{c}0.462^{* *} \\
(0.183)\end{array}$ \\
\hline Textile/apparel & $\begin{array}{c}0.201 \\
(0.125)\end{array}$ & $\begin{array}{c}0.316^{* *} \\
(0.160)\end{array}$ & $\begin{array}{c}0.122 \\
(0.139)\end{array}$ & $\begin{array}{c}0.243 \\
(0.157)\end{array}$ & $\begin{array}{l}-0.101 \\
(0.148)\end{array}$ & $\begin{array}{l}-0.092 \\
(0.210)\end{array}$ & $\begin{array}{c}0.403^{* *} \\
(0.177)\end{array}$ & $\begin{array}{c}0.511^{* *} \\
(0.222)\end{array}$ & $\begin{array}{c}0.518^{* *} \\
(0.219)\end{array}$ & $\begin{array}{c}0.640^{* * *} \\
(0.245)\end{array}$ \\
\hline Wholesale/retail & $\begin{array}{l}-0.034 \\
(0.095)\end{array}$ & $\begin{array}{c}0.033 \\
(0.099)\end{array}$ & $\begin{array}{c}-0.242^{* *} \\
(0.112)\end{array}$ & $\begin{array}{c}-0.183^{*} \\
(0.111)\end{array}$ & $\begin{array}{l}-0.070 \\
(0.085)\end{array}$ & $\begin{array}{l}-0.016 \\
(0.106)\end{array}$ & $\begin{array}{c}0.096 \\
(0.129)\end{array}$ & $\begin{array}{c}0.197 \\
(0.156)\end{array}$ & $\begin{array}{c}0.164 \\
(0.167)\end{array}$ & $\begin{array}{c}0.143 \\
(0.169)\end{array}$ \\
\hline Transport/communication & $\begin{array}{l}-0.087 \\
(0.095)\end{array}$ & $\begin{array}{l}-0.045 \\
(0.106)\end{array}$ & $\begin{array}{c}-0.267^{* *} \\
(0.115)\end{array}$ & $\begin{array}{c}-0.259^{* *} \\
(0.120)\end{array}$ & $\begin{array}{l}-0.078 \\
(0.089)\end{array}$ & $\begin{array}{l}-0.065 \\
(0.118)\end{array}$ & $\begin{array}{c}0.082 \\
(0.150)\end{array}$ & $\begin{array}{c}0.181 \\
(0.161)\end{array}$ & $\begin{array}{c}0.400^{* *} \\
(0.172)\end{array}$ & $\begin{array}{l}0.297^{*} \\
(0.176)\end{array}$ \\
\hline Public service & $\begin{array}{c}0.003 \\
(0.089)\end{array}$ & $\begin{array}{c}0.073 \\
(0.098)\end{array}$ & $\begin{array}{l}-0.048 \\
(0.108)\end{array}$ & $\begin{array}{c}0.018 \\
(0.110)\end{array}$ & $\begin{array}{l}-0.083 \\
(0.085)\end{array}$ & $\begin{array}{l}-0.043 \\
(0.105)\end{array}$ & $\begin{array}{c}0.275^{* *} \\
(0.124)\end{array}$ & $\begin{array}{c}0.425^{* * *} \\
(0.150)\end{array}$ & $\begin{array}{c}0.351^{* *} \\
(0.163)\end{array}$ & $\begin{array}{c}0.346^{* *} \\
(0.166)\end{array}$ \\
\hline Financials/private services & $\begin{array}{l}-0.008 \\
(0.091)\end{array}$ & $\begin{array}{c}0.075 \\
(0.098)\end{array}$ & $\begin{array}{c}-0.191^{*} \\
(0.110)\end{array}$ & $\begin{array}{l}-0.122 \\
(0.110)\end{array}$ & $\begin{array}{l}-0.097 \\
(0.088)\end{array}$ & $\begin{array}{l}-0.039 \\
(0.105)\end{array}$ & $\begin{array}{c}0.098 \\
(0.136)\end{array}$ & $\begin{array}{l}0.268^{*} \\
(0.153)\end{array}$ & $\begin{array}{l}0.279^{*} \\
(0.167)\end{array}$ & $\begin{array}{c}0.247 \\
(0.168)\end{array}$ \\
\hline Not Caregorized & $\begin{array}{c}0.056 \\
(0.094)\end{array}$ & $\begin{array}{c}0.074 \\
(0.107)\end{array}$ & $\begin{array}{c}0.080 \\
(0.118)\end{array}$ & $\begin{array}{c}0.103 \\
(0.119)\end{array}$ & $\begin{array}{l}-0.005 \\
(0.095)\end{array}$ & $\begin{array}{c}0.028 \\
(0.117)\end{array}$ & $\begin{array}{c}0.362^{* * *} \\
(0.134)\end{array}$ & $\begin{array}{c}0.457^{* * *} \\
(0.161)\end{array}$ & $\begin{array}{l}0.339^{*} \\
(0.182)\end{array}$ & $\begin{array}{c}0.259 \\
(0.180)\end{array}$ \\
\hline Constant & $\begin{array}{c}7.600^{* * *} \\
(0.102)\end{array}$ & $\begin{array}{c}7.455^{* * *} \\
(0.137)\end{array}$ & $\begin{array}{c}7.627^{* * *} \\
(0.148)\end{array}$ & $\begin{array}{c}7.564^{* * *} \\
(0.143)\end{array}$ & $\begin{array}{c}8.976^{* * *} \\
(0.119)\end{array}$ & $\begin{array}{c}8.651^{* * *} \\
(0.165)\end{array}$ & $\begin{array}{c}7.586^{* * *} \\
(0.204)\end{array}$ & $\begin{array}{c}7.338^{* * *} \\
(0.212)\end{array}$ & $\begin{array}{c}4.678^{* * *} \\
(0.201)\end{array}$ & $\begin{array}{c}4.703^{* * *} \\
(0.197)\end{array}$ \\
\hline \multicolumn{11}{|l|}{ First Stage ( $Y_{i t}:$ Work-linked) } \\
\hline Occ./ind. gender disparity & $\begin{array}{c}-0.011^{* * *} \\
(0.003)\end{array}$ & & $\begin{array}{c}-0.011^{* * *} \\
(0.003)\end{array}$ & & $\begin{array}{c}-0.013^{* * *} \\
(0.003)\end{array}$ & & $\begin{array}{c}-0.011^{* * *} \\
(0.003)\end{array}$ & & $\begin{array}{c}-0.013^{* * *} \\
(0.003)\end{array}$ & \\
\hline $\mathrm{P}(\mathrm{WL} \mid \mathrm{PPO})$ & & $\begin{array}{c}0.010^{* * *} \\
(0.002)\end{array}$ & & $\begin{array}{c}0.010^{* * *} \\
(0.002)\end{array}$ & & $\begin{array}{c}0.009^{* * *} \\
(0.003)\end{array}$ & & $\begin{array}{c}0.010^{* * *} \\
(0.002)\end{array}$ & & $\begin{array}{c}0.009^{* * *} \\
(0.003)\end{array}$ \\
\hline \multicolumn{11}{|l|}{ Individual characteristics } \\
\hline Female & $\begin{array}{c}0.022 \\
(0.054)\end{array}$ & $\begin{array}{c}0.068^{* * *} \\
(0.018)\end{array}$ & $\begin{array}{c}0.021 \\
(0.054)\end{array}$ & $\begin{array}{c}0.067^{* * *} \\
(0.018)\end{array}$ & $\begin{array}{c}0.006 \\
(0.052)\end{array}$ & $\begin{array}{c}0.077^{* * *} \\
(0.021)\end{array}$ & $\begin{array}{c}0.026 \\
(0.054)\end{array}$ & $\begin{array}{c}0.071^{* * *} \\
(0.019)\end{array}$ & $\begin{array}{c}0.004 \\
(0.053)\end{array}$ & $\begin{array}{c}0.074^{* * *} \\
(0.021)\end{array}$ \\
\hline \multicolumn{11}{|l|}{ Age (Ref.: 25-34 years) } \\
\hline $35-44$ years & $\begin{array}{c}-0.108^{* *} \\
(0.046)\end{array}$ & $\begin{array}{c}-0.118^{* * *} \\
(0.043)\end{array}$ & $\begin{array}{c}-0.108^{* *} \\
(0.046)\end{array}$ & $\begin{array}{c}-0.119^{* * *} \\
(0.043)\end{array}$ & $\begin{array}{l}-0.027 \\
(0.068)\end{array}$ & $\begin{array}{l}-0.029 \\
(0.056)\end{array}$ & $\begin{array}{c}-0.111^{* *} \\
(0.047)\end{array}$ & $\begin{array}{c}-0.121^{* * *} \\
(0.046)\end{array}$ & $\begin{array}{l}-0.032 \\
(0.062)\end{array}$ & $\begin{array}{l}-0.038 \\
(0.054)\end{array}$ \\
\hline 45-54 years & $\begin{array}{c}-0.191^{* * *} \\
(0.070)\end{array}$ & $\begin{array}{c}-0.230^{* * *} \\
(0.066)\end{array}$ & $\begin{array}{c}-0.191^{* * *} \\
(0.070)\end{array}$ & $\begin{array}{c}-0.230^{* * *} \\
(0.066)\end{array}$ & $\begin{array}{l}-0.117 \\
(0.096)\end{array}$ & $\begin{array}{l}-0.124 \\
(0.077)\end{array}$ & $\begin{array}{c}-0.197^{* * *} \\
(0.071)\end{array}$ & $\begin{array}{c}-0.237^{* * *} \\
(0.069)\end{array}$ & $\begin{array}{l}-0.126 \\
(0.094)\end{array}$ & $\begin{array}{c}-0.138^{*} \\
(0.076)\end{array}$ \\
\hline $55-64$ years & $\begin{array}{c}-0.098 \\
(0.099)\end{array}$ & $\begin{array}{c}-0.159^{*} \\
(0.087)\end{array}$ & $\begin{array}{c}-0.099 \\
(0.099)\end{array}$ & $\begin{array}{c}-0.162^{*} \\
(0.087)\end{array}$ & $\begin{array}{l}-0.058 \\
(0.135)\end{array}$ & $\begin{array}{l}-0.090 \\
(0.099)\end{array}$ & $\begin{array}{c}-0.111 \\
(0.100)\end{array}$ & $\begin{array}{c}-0.173^{*} \\
(0.090)\end{array}$ & $\begin{array}{c}-0.074 \\
(0.132)\end{array}$ & $\begin{array}{l}-0.104 \\
(0.098)\end{array}$ \\
\hline \multicolumn{11}{|l|}{ Regional characteristics } \\
\hline Rural Area & $\begin{array}{c}0.047 \\
(0.050)\end{array}$ & $\begin{array}{c}0.068 \\
(0.049)\end{array}$ & $\begin{array}{c}0.044 \\
(0.050)\end{array}$ & $\begin{array}{c}0.065 \\
(0.049)\end{array}$ & $\begin{array}{c}0.076 \\
(0.061)\end{array}$ & $\begin{array}{c}0.136^{* *} \\
(0.056)\end{array}$ & $\begin{array}{c}0.041 \\
(0.051)\end{array}$ & $\begin{array}{c}0.067 \\
(0.051)\end{array}$ & $\begin{array}{c}0.056 \\
(0.060)\end{array}$ & $\begin{array}{l}0.108^{*} \\
(0.055)\end{array}$ \\
\hline Lower Saxony & $\begin{array}{l}-0.116 \\
(0.148)\end{array}$ & & $\begin{array}{c}-0.116 \\
(0.149)\end{array}$ & & $\begin{array}{l}-0.158 \\
(0.148)\end{array}$ & & $\begin{array}{c}-0.131 \\
(0.153)\end{array}$ & & $\begin{array}{l}-0.121 \\
(0.145)\end{array}$ & \\
\hline Bremen & $\begin{array}{c}0.101 \\
(0.254)\end{array}$ & & $\begin{array}{c}0.097 \\
(0.255)\end{array}$ & & $\begin{array}{l}-0.097 \\
(0.334)\end{array}$ & & $\begin{array}{c}0.068 \\
(0.253)\end{array}$ & & $\begin{array}{c}-0.004 \\
(0.300)\end{array}$ & \\
\hline North Rhine-Westphalia & $\begin{array}{l}-0.000 \\
(0.162)\end{array}$ & & $\begin{array}{c}0.001 \\
(0.163)\end{array}$ & & $\begin{array}{l}-0.164 \\
(0.173)\end{array}$ & & $\begin{array}{c}-0.018 \\
(0.163)\end{array}$ & & $\begin{array}{l}-0.133 \\
(0.161)\end{array}$ & \\
\hline Hesse & $\begin{array}{l}-0.108 \\
(0.167)\end{array}$ & & $\begin{array}{l}-0.107 \\
(0.168)\end{array}$ & & $\begin{array}{l}-0.217 \\
(0.167)\end{array}$ & & $\begin{array}{c}-0.110 \\
(0.176)\end{array}$ & & $\begin{array}{l}-0.195 \\
(0.161)\end{array}$ & \\
\hline Rhinel.-Palatinate & $\begin{array}{c}0.045 \\
(0.160)\end{array}$ & & $\begin{array}{c}0.048 \\
(0.160)\end{array}$ & & $\begin{array}{l}-0.048 \\
(0.165)\end{array}$ & & $\begin{array}{c}0.017 \\
(0.166)\end{array}$ & & $\begin{array}{c}-0.037 \\
(0.160)\end{array}$ & \\
\hline Baden-Wuerttemberg & $\begin{array}{c}0.029 \\
(0.154)\end{array}$ & & $\begin{array}{c}0.030 \\
(0.155)\end{array}$ & & $\begin{array}{l}-0.141 \\
(0.172)\end{array}$ & & $\begin{array}{c}0.020 \\
(0.156)\end{array}$ & & $\begin{array}{l}-0.120 \\
(0.163)\end{array}$ & \\
\hline Bavaria & $\begin{array}{c}0.121 \\
(0.143)\end{array}$ & & $\begin{array}{c}0.123 \\
(0.144)\end{array}$ & & $\begin{array}{c}-0.032 \\
(0.159)\end{array}$ & & $\begin{array}{c}0.109 \\
(0.143)\end{array}$ & & $\begin{array}{c}0.005 \\
(0.148)\end{array}$ & \\
\hline Saarland & $\begin{array}{l}-0.265 \\
(0.217)\end{array}$ & & $\begin{array}{c}-0.274 \\
(0.218)\end{array}$ & & $\begin{array}{r}-0.616^{*} \\
(0.350)\end{array}$ & & $\begin{array}{l}-0.306 \\
(0.215)\end{array}$ & & $\begin{array}{c}-0.500^{*} \\
(0.268)\end{array}$ & \\
\hline Berlin & $\begin{array}{c}0.108 \\
(0.163)\end{array}$ & & $\begin{array}{c}0.110 \\
(0.164)\end{array}$ & & $\begin{array}{l}-0.020 \\
(0.194)\end{array}$ & & $\begin{array}{c}0.099 \\
(0.167)\end{array}$ & & $\begin{array}{c}0.029 \\
(0.185)\end{array}$ & \\
\hline Brandenburg & $\begin{array}{c}-0.123 \\
(0.165)\end{array}$ & & $\begin{array}{c}-0.122 \\
(0.165)\end{array}$ & & $\begin{array}{l}-0.089 \\
(0.170)\end{array}$ & & $\begin{array}{l}-0.137 \\
(0.171)\end{array}$ & & $\begin{array}{l}-0.077 \\
(0.165)\end{array}$ & \\
\hline Mecklenburg-Western Pomerania & $\begin{array}{c}0.109 \\
(0.227)\end{array}$ & & $\begin{array}{c}0.106 \\
(0.227)\end{array}$ & & $\begin{array}{c}0.138 \\
(0.233)\end{array}$ & & $\begin{array}{c}0.136 \\
(0.230)\end{array}$ & & $\begin{array}{c}0.161 \\
(0.230)\end{array}$ & \\
\hline Saxony & $\begin{array}{l}-0.121 \\
(0.152)\end{array}$ & & $\begin{array}{l}-0.122 \\
(0.153)\end{array}$ & & $\begin{array}{l}-0.135 \\
(0.160)\end{array}$ & & $\begin{array}{c}-0.156 \\
(0.162)\end{array}$ & & $\begin{array}{l}-0.115 \\
(0.154)\end{array}$ & \\
\hline Saxony-Anhalt & $\begin{array}{l}-0.090 \\
(0.175)\end{array}$ & & $\begin{array}{l}-0.087 \\
(0.176)\end{array}$ & & $\begin{array}{c}-0.084 \\
(0.197)\end{array}$ & & $\begin{array}{c}-0.094 \\
(0.175)\end{array}$ & & $\begin{array}{l}-0.097 \\
(0.200)\end{array}$ & \\
\hline Thuringia & $\begin{array}{c}0.172 \\
(0.150)\end{array}$ & & $\begin{array}{c}0.172 \\
(0.150)\end{array}$ & & $\begin{array}{c}0.161 \\
(0.156)\end{array}$ & & $\begin{array}{c}0.174 \\
(0.152)\end{array}$ & & $\begin{array}{c}0.192 \\
(0.150)\end{array}$ & \\
\hline Years of education & $\begin{array}{c}0.021^{* *} \\
(0.009)\end{array}$ & $\begin{array}{c}0.037^{* * *} \\
(0.006)\end{array}$ & $\begin{array}{c}0.021^{* *} \\
(0.009)\end{array}$ & $\begin{array}{c}0.037^{* * *} \\
(0.006)\end{array}$ & $\begin{array}{c}0.035^{* * *} \\
(0.010)\end{array}$ & $\begin{array}{c}0.045^{* * *} \\
(0.007)\end{array}$ & $\begin{array}{c}0.021^{* *} \\
(0.009)\end{array}$ & $\begin{array}{c}0.038^{* * *} \\
(0.006)\end{array}$ & $\begin{array}{c}0.033^{* * *} \\
(0.010)\end{array}$ & $\begin{array}{c}0.043^{* * *} \\
(0.006)\end{array}$ \\
\hline \multicolumn{11}{|l|}{ Household characteristics } \\
\hline Married & $\begin{array}{c}-0.115^{* *} \\
(0.051)\end{array}$ & $\begin{array}{c}-0.145^{* *} \\
(0.062)\end{array}$ & $\begin{array}{c}-0.115^{* *} \\
(0.051)\end{array}$ & $\begin{array}{c}-0.146^{* *} \\
(0.062)\end{array}$ & $\begin{array}{c}-0.139^{* * *} \\
(0.052)\end{array}$ & $\begin{array}{c}-0.164^{* *} \\
(0.071)\end{array}$ & $\begin{array}{c}-0.113^{* *} \\
(0.052)\end{array}$ & $\begin{array}{c}-0.140^{* *} \\
(0.063)\end{array}$ & $\begin{array}{c}-0.130^{* * *} \\
(0.049)\end{array}$ & $\begin{array}{c}-0.156^{* *} \\
(0.069)\end{array}$ \\
\hline Number of children in $\mathrm{HH}$ & $\begin{array}{l}0.039^{*} \\
(0.021)\end{array}$ & $\begin{array}{c}0.029 \\
(0.022)\end{array}$ & $\begin{array}{l}0.040^{*} \\
(0.021)\end{array}$ & $\begin{array}{c}0.030 \\
(0.022)\end{array}$ & $\begin{array}{c}0.016 \\
(0.026)\end{array}$ & $\begin{array}{c}0.016 \\
(0.028)\end{array}$ & $\begin{array}{c}0.048^{* *} \\
(0.024)\end{array}$ & $\begin{array}{c}0.034 \\
(0.024)\end{array}$ & $\begin{array}{c}0.027 \\
(0.024)\end{array}$ & $\begin{array}{c}0.025 \\
(0.027)\end{array}$ \\
\hline Parntership length & $\begin{array}{c}-0.016^{* * *} \\
(0.003)\end{array}$ & $\begin{array}{c}-0.016^{* * *} \\
(0.004)\end{array}$ & $\begin{array}{c}-0.016^{* * *} \\
(0.003)\end{array}$ & $\begin{array}{c}-0.016^{* * *} \\
(0.004)\end{array}$ & $\begin{array}{c}-0.016^{* * *} \\
(0.004)\end{array}$ & $\begin{array}{c}-0.016^{* * *} \\
(0.004)\end{array}$ & $\begin{array}{c}-0.017^{* * *} \\
(0.003)\end{array}$ & $\begin{array}{c}-0.016^{* * *} \\
(0.004)\end{array}$ & $\begin{array}{c}-0.016^{* * *} \\
(0.004)\end{array}$ & $\begin{array}{c}-0.016^{* * *} \\
(0.004)\end{array}$ \\
\hline Censored partnership length & $\begin{array}{l}-0.040 \\
(0.051)\end{array}$ & $\begin{array}{c}-0.084 \\
(0.059)\end{array}$ & $\begin{array}{c}-0.039 \\
(0.052)\end{array}$ & $\begin{array}{c}-0.083 \\
(0.059)\end{array}$ & $\begin{array}{l}-0.047 \\
(0.070)\end{array}$ & $\begin{array}{l}-0.073 \\
(0.067)\end{array}$ & $\begin{array}{c}-0.036 \\
(0.054)\end{array}$ & $\begin{array}{l}-0.079 \\
(0.060)\end{array}$ & $\begin{array}{c}-0.080 \\
(0.067)\end{array}$ & $\begin{array}{c}-0.103 \\
(0.065)\end{array}$ \\
\hline
\end{tabular}


Table S.6: Full Estimation Results - Instrumental Variables (ctd.)

\begin{tabular}{|c|c|c|c|c|c|c|c|c|c|c|}
\hline & \multicolumn{2}{|c|}{ Life } & \multicolumn{2}{|c|}{ Work } & \multicolumn{2}{|c|}{ Family } & \multicolumn{2}{|c|}{ Leisure } & \multicolumn{2}{|c|}{ Income } \\
\hline & IV1 & IV2 & IV1 & IV2 & IV1 & IV2 & IV1 & IV2 & IV1 & IV2 \\
\hline \multicolumn{11}{|c|}{ Firm size (Ref.: small, under 20 employees) } \\
\hline medium (20-199) & $\begin{array}{c}0.065 \\
(0.059)\end{array}$ & $\begin{array}{c}0.104^{* *} \\
(0.049)\end{array}$ & $\begin{array}{c}0.064 \\
(0.060)\end{array}$ & $\begin{array}{c}0.104^{* *} \\
(0.049)\end{array}$ & $\begin{array}{l}0.120^{*} \\
(0.071)\end{array}$ & $\begin{array}{c}0.144^{* *} \\
(0.059)\end{array}$ & $\begin{array}{c}0.044 \\
(0.060)\end{array}$ & $\begin{array}{l}0.086^{*} \\
(0.051)\end{array}$ & $\begin{array}{c}0.144^{* *} \\
(0.069)\end{array}$ & $\begin{array}{c}0.173^{* * * *} \\
(0.057)\end{array}$ \\
\hline large (200 and more) & $\begin{array}{c}0.191^{* * *} \\
(0.067)\end{array}$ & $\begin{array}{c}0.273^{* * *} \\
(0.048)\end{array}$ & $\begin{array}{c}0.189^{* * *} \\
(0.067)\end{array}$ & $\begin{array}{c}0.272^{* * *} \\
(0.048)\end{array}$ & $\begin{array}{c}0.221^{* * *} \\
(0.065)\end{array}$ & $\begin{array}{c}0.293^{* * *} \\
(0.055)\end{array}$ & $\begin{array}{c}0.175^{* *} \\
(0.068)\end{array}$ & $\begin{array}{c}0.263^{* * *} \\
(0.050)\end{array}$ & $\begin{array}{c}0.236^{* * *} \\
(0.066)\end{array}$ & $\begin{array}{c}0.318^{* * *} \\
(0.054)\end{array}$ \\
\hline In trained occupation & $\begin{array}{c}0.043 \\
(0.043)\end{array}$ & $\begin{array}{c}0.089^{* * *} \\
(0.034)\end{array}$ & $\begin{array}{c}0.043 \\
(0.043)\end{array}$ & $\begin{array}{c}0.089^{* * *} \\
(0.034)\end{array}$ & $\begin{array}{c}0.125^{* * *} \\
(0.046)\end{array}$ & $\begin{array}{c}0.113^{* * *} \\
(0.041)\end{array}$ & $\begin{array}{c}0.048 \\
(0.044)\end{array}$ & $\begin{array}{c}0.085^{* *} \\
(0.034)\end{array}$ & $\begin{array}{c}0.130^{* * *} \\
(0.044)\end{array}$ & $\begin{array}{c}0.119^{* * *} \\
(0.040)\end{array}$ \\
\hline Fixed-term contract & $\begin{array}{c}0.085 \\
(0.099)\end{array}$ & $\begin{array}{c}0.067 \\
(0.047)\end{array}$ & $\begin{array}{c}0.086 \\
(0.099)\end{array}$ & $\begin{array}{c}0.068 \\
(0.047)\end{array}$ & $\begin{array}{c}0.102 \\
(0.103)\end{array}$ & $\begin{array}{l}0.105^{*} \\
(0.058)\end{array}$ & $\begin{array}{c}0.096 \\
(0.104)\end{array}$ & $\begin{array}{c}0.076 \\
(0.050)\end{array}$ & $\begin{array}{c}0.104 \\
(0.104)\end{array}$ & $\begin{array}{l}0.104^{*} \\
(0.057)\end{array}$ \\
\hline Full-time employed & $\begin{array}{c}0.174^{* * *} \\
(0.050)\end{array}$ & $\begin{array}{c}0.121^{* * *} \\
(0.042)\end{array}$ & $\begin{array}{c}0.174^{* * *} \\
(0.050)\end{array}$ & $\begin{array}{c}0.120^{* * * *} \\
(0.042)\end{array}$ & $\begin{array}{c}0.098^{* *} \\
(0.046)\end{array}$ & $\begin{array}{c}0.110^{* *} \\
(0.050)\end{array}$ & $\begin{array}{c}0.189^{* * * *} \\
(0.051)\end{array}$ & $\begin{array}{c}0.138^{* * *} \\
(0.044)\end{array}$ & $\begin{array}{c}0.101^{* *} \\
(0.047)\end{array}$ & $\begin{array}{c}0.107^{* *} \\
(0.049)\end{array}$ \\
\hline \multicolumn{11}{|l|}{ Partner characteristics } \\
\hline Years of Education & $\begin{array}{c}0.035^{* *} \\
(0.014)\end{array}$ & $\begin{array}{c}0.043^{* * *} \\
(0.005)\end{array}$ & $\begin{array}{c}0.035^{* *} \\
(0.014)\end{array}$ & $\begin{array}{c}0.043^{* * *} \\
(0.005)\end{array}$ & $\begin{array}{c}0.050^{* * *} \\
(0.015)\end{array}$ & $\begin{array}{c}0.052^{* * *} \\
(0.006)\end{array}$ & $\begin{array}{c}0.036^{* * *} \\
(0.014)\end{array}$ & $\begin{array}{c}0.043^{* * *} \\
(0.006)\end{array}$ & $\begin{array}{c}0.048^{* * *} \\
(0.014)\end{array}$ & $\begin{array}{c}0.050^{* * *} \\
(0.006)\end{array}$ \\
\hline Tenure & $\begin{array}{c}0.013^{* * *} \\
(0.003)\end{array}$ & $\begin{array}{c}0.014^{* * *} \\
(0.002)\end{array}$ & $\begin{array}{c}0.013^{* * *} \\
(0.003)\end{array}$ & $\begin{array}{c}0.014^{* * *} \\
(0.002)\end{array}$ & $\begin{array}{c}0.014^{* * *} \\
(0.004)\end{array}$ & $\begin{array}{c}0.015^{* * *} \\
(0.002)\end{array}$ & $\begin{array}{c}0.013^{* * *} \\
(0.003)\end{array}$ & $\begin{array}{c}0.014^{* * *} \\
(0.002)\end{array}$ & $\begin{array}{c}0.014^{* * *} \\
(0.004)\end{array}$ & $\begin{array}{c}0.015^{* * *} \\
(0.002)\end{array}$ \\
\hline In trained occupation & $\begin{array}{c}0.018 \\
(0.059)\end{array}$ & $\begin{array}{c}0.096^{* * *} \\
(0.034)\end{array}$ & $\begin{array}{c}0.018 \\
(0.059)\end{array}$ & $\begin{array}{c}0.095^{* * *} \\
(0.034)\end{array}$ & $\begin{array}{c}0.101 \\
(0.063)\end{array}$ & $\begin{array}{c}0.117^{* * *} \\
(0.041)\end{array}$ & $\begin{array}{c}0.024 \\
(0.059)\end{array}$ & $\begin{array}{c}0.097^{* * *} \\
(0.035)\end{array}$ & $\begin{array}{l}0.100^{*} \\
(0.061)\end{array}$ & $\begin{array}{c}0.123^{* * *} \\
(0.040)\end{array}$ \\
\hline Fixed-term contract & $\begin{array}{c}0.068 \\
(0.106)\end{array}$ & $\begin{array}{c}0.066 \\
(0.046)\end{array}$ & $\begin{array}{c}0.067 \\
(0.106)\end{array}$ & $\begin{array}{c}0.064 \\
(0.046)\end{array}$ & $\begin{array}{c}0.110 \\
(0.112)\end{array}$ & $\begin{array}{l}0.100^{*} \\
(0.059)\end{array}$ & $\begin{array}{c}0.074 \\
(0.109)\end{array}$ & $\begin{array}{c}0.073 \\
(0.049)\end{array}$ & $\begin{array}{c}0.106 \\
(0.113)\end{array}$ & $\begin{array}{l}0.095^{*} \\
(0.056)\end{array}$ \\
\hline Full-time employed & $\begin{array}{c}0.033 \\
(0.063)\end{array}$ & $\begin{array}{c}0.012 \\
(0.038)\end{array}$ & $\begin{array}{c}0.034 \\
(0.063)\end{array}$ & $\begin{array}{c}0.012 \\
(0.038)\end{array}$ & $\begin{array}{c}0.025 \\
(0.058)\end{array}$ & $\begin{array}{c}0.038 \\
(0.045)\end{array}$ & $\begin{array}{c}0.037 \\
(0.064)\end{array}$ & $\begin{array}{c}0.016 \\
(0.039)\end{array}$ & $\begin{array}{c}0.025 \\
(0.060)\end{array}$ & $\begin{array}{c}0.031 \\
(0.045)\end{array}$ \\
\hline Constant & $\begin{array}{c}-2.373^{* * *} \\
(0.432)\end{array}$ & $\begin{array}{c}-3.155^{* * *} \\
(0.165)\end{array}$ & $\begin{array}{c}-2.376^{* * *} \\
(0.433)\end{array}$ & $\begin{array}{c}-3.153^{* * *} \\
(0.165)\end{array}$ & $\begin{array}{c}-2.755^{* * *} \\
(0.502)\end{array}$ & $\begin{array}{c}-3.551^{* * *} \\
(0.198)\end{array}$ & $\begin{array}{c}-2.398^{* * *} \\
(0.432)\end{array}$ & $\begin{array}{c}-3.194^{* * *} \\
(0.170)\end{array}$ & $\begin{array}{c}-2.746^{* * *} \\
(0.489)\end{array}$ & $\begin{array}{c}-3.508^{* * *} \\
(0.193)\end{array}$ \\
\hline athrho & $\begin{array}{c}-0.103^{* * *} \\
(0.031)\end{array}$ & $\begin{array}{c}-0.118^{* * *} \\
(0.024)\end{array}$ & $\begin{array}{c}-0.090^{* * *} \\
(0.028)\end{array}$ & $\begin{array}{c}-0.091^{* * *} \\
(0.028)\end{array}$ & $\begin{array}{c}-0.068^{* *} \\
(0.032)\end{array}$ & $\begin{array}{c}-0.087^{* * *} \\
(0.024)\end{array}$ & $\begin{array}{c}-0.038 \\
(0.046)\end{array}$ & $\begin{array}{c}-0.029 \\
(0.054)\end{array}$ & $\begin{array}{c}-0.158^{* * *} \\
(0.042)\end{array}$ & $\begin{array}{c}-0.144^{* * *} \\
(0.048)\end{array}$ \\
\hline lnsigma & $\begin{array}{c}0.394^{* * * *} \\
(0.006)\end{array}$ & $\begin{array}{c}0.380^{* * *} \\
(0.006)\end{array}$ & $\begin{array}{c}0.644^{* * *} \\
(0.006)\end{array}$ & $\begin{array}{c}0.639^{* * * *} \\
(0.005)\end{array}$ & $\begin{array}{c}0.458^{* * *} \\
(0.006)\end{array}$ & $\begin{array}{c}0.457^{* * * *} \\
(0.008)\end{array}$ & $\begin{array}{c}0.739^{* * *} \\
(0.006)\end{array}$ & $\begin{array}{c}0.728^{* * * *} \\
(0.005)\end{array}$ & $\begin{array}{c}0.677^{* * * *} \\
(0.008)\end{array}$ & $\begin{array}{c}0.674^{* * *} \\
(0.006)\end{array}$ \\
\hline $\mathrm{N}$ & 122456 & 98152 & 122456 & 98152 & 68782 & 58713 & 111288 & 89355 & 78016 & 66281 \\
\hline Year FE & $\checkmark$ & $\checkmark$ & $\checkmark$ & $\checkmark$ & $\checkmark$ & $\checkmark$ & $\checkmark$ & $\checkmark$ & $\checkmark$ & $\checkmark$ \\
\hline
\end{tabular}

Source: SOEP [2019]; Bundeagentur für Arbeit $\overline{2016 \mathrm{a}}$ b). Own calculations.

Note: Clustered standard errors in parentheses. ${ }^{*} p<0.1,{ }^{* *} p<0.05,{ }^{* * *} p<0.01$ 
Table S.7: Robustness checks - Link type

\begin{tabular}{|c|c|c|c|c|c|}
\hline & Life & Work & Family & Leisure & Income \\
\hline \multicolumn{6}{|c|}{ Explanatory variable - Occupational work link } \\
\hline Conditional OLS & $\begin{array}{c}0.055 \\
(0.042)\end{array}$ & $\begin{array}{c}0.042 \\
(0.046)\end{array}$ & $\begin{array}{c}-0.008 \\
(0.058)\end{array}$ & $\begin{array}{c}-0.146^{* *} \\
(0.058)\end{array}$ & $\begin{array}{c}0.154^{* * *} \\
(0.057)\end{array}$ \\
\hline $\mathrm{N}$ & 122456 & 122456 & 68782 & 111288 & 78016 \\
\hline $\mathbf{X}_{i t}$ & $\checkmark$ & $\checkmark$ & $\checkmark$ & $\checkmark$ & $\checkmark$ \\
\hline IV 1 - Occ./ind. gender disparity & $\begin{array}{c}0.373^{* * *} \\
(0.103)\end{array}$ & $\begin{array}{c}0.369^{* * *} \\
(0.116)\end{array}$ & $\begin{array}{c}0.209^{*} \\
(0.112)\end{array}$ & $\begin{array}{c}0.112 \\
(0.208)\end{array}$ & $\begin{array}{c}0.812^{* * * *} \\
(0.166)\end{array}$ \\
\hline $\mathrm{N}$ & 122456 & 122456 & 68782 & 111288 & 78016 \\
\hline FS F-stat & 15.2 & 15.2 & 14.37 & 14.25 & 13.15 \\
\hline $\mathbf{X}_{i t}$ & $\checkmark$ & $\checkmark$ & $\checkmark$ & $\checkmark$ & $\checkmark$ \\
\hline IV2 - P(WL | PPO) & $\begin{array}{c}0.431^{* * *} \\
(0.091)\end{array}$ & $\begin{array}{c}0.383^{* * *} \\
(0.126)\end{array}$ & $\begin{array}{c}0.259^{* *} \\
(0.105)\end{array}$ & $\begin{array}{l}-0.113 \\
(0.553)\end{array}$ & $\begin{array}{c}0.785^{* * *} \\
(0.176)\end{array}$ \\
\hline $\mathrm{N}$ & 98153 & 98153 & 58711 & 89357 & 66279 \\
\hline FS F-stat & 14.76 & 14.76 & 15.16 & 7.4 & 9.49 \\
\hline $\mathbf{X}_{i t}$ & $\mathfrak{S}^{1}$ & $\mathfrak{J}^{1}$ & $\mathfrak{J}^{1}$ & $\mathfrak{J}^{2}$ & $\mathfrak{S}^{1}$ \\
\hline \multicolumn{6}{|c|}{ Explanatory variable - Industrial work link } \\
\hline Conditional OLS & $\begin{array}{c}0.083^{* * *} \\
(0.028)\end{array}$ & $\begin{array}{c}0.083^{* * *} \\
(0.031)\end{array}$ & $\begin{array}{c}0.075^{* *} \\
(0.036)\end{array}$ & $\begin{array}{c}-0.078^{*} \\
(0.040)\end{array}$ & $\begin{array}{c}0.193^{* * *} \\
(0.041)\end{array}$ \\
\hline $\mathrm{N}$ & 122456 & 122456 & 68782 & 111288 & 78016 \\
\hline $\mathbf{X}_{i t}$ & $\checkmark$ & $\checkmark$ & $\checkmark$ & $\checkmark$ & $\checkmark$ \\
\hline IV 1 - Occ./ind. gender disparity & $\begin{array}{c}0.204^{* *} \\
(0.102)\end{array}$ & $\begin{array}{c}0.319^{* * *} \\
(0.101)\end{array}$ & $\begin{array}{c}0.187^{* *} \\
(0.085)\end{array}$ & $\begin{array}{l}-0.053 \\
(0.813)\end{array}$ & $\begin{array}{c}0.652^{* * *} \\
(0.117)\end{array}$ \\
\hline $\mathrm{N}$ & 122456 & 122456 & 68782 & 111288 & 78016 \\
\hline FS F-stat & 31.83 & 31.83 & 31.56 & 38.29 & 39.68 \\
\hline $\mathbf{X}_{i t}$ & $\checkmark$ & $\checkmark$ & $\checkmark$ & $\mathfrak{V}^{2}$ & $\checkmark$ \\
\hline IV2 - P(WL - PPO $)$ & $\begin{array}{c}0.247^{* * *} \\
(0.085)\end{array}$ & $\begin{array}{c}0.343^{* * *} \\
(0.101)\end{array}$ & $\begin{array}{c}0.245^{* * *} \\
(0.082)\end{array}$ & $\begin{array}{l}-0.089 \\
(0.307)\end{array}$ & $\begin{array}{c}0.582^{* * *} \\
(0.141)\end{array}$ \\
\hline $\mathrm{N}$ & 98153 & 98153 & 58711 & 89357 & 66279 \\
\hline FS F-stat & 8.34 & 8.34 & 8.49 & 8.04 & 6.34 \\
\hline $\mathbf{X}_{i t}$ & $\mathcal{J}^{1}$ & $\mathcal{S}^{1}$ & $\mathcal{S}^{1}$ & $\checkmark^{2}$ & $\mathfrak{J}^{1}$ \\
\hline
\end{tabular}




\section{Controlling for personality traits}

In the SOEP, the big five personality traits are surveyed using self-reported assessments of a list of 15 items Gerlitz and Schupp (2005). The resulting factors are constructed using a simple average over the corresponding three items for each factor. Controlling for personality, however, comes at the cost of a loss of observations, as the Big Five traits were elicited in three SOEP waves only (2005, 2009, 2013). To keep a reasonably sized sample, the missing values (other waves) are imputed by the withinindividual average over all available observations of the traits. In the same way, we control for people's risk preference (single item on people's risk attitude, measured in 2004, 2006 and annually since 2008), time preference (single item on people's patience, measured in 2008, 2013, 2018), and optimism (single item measured in 1999, 2005, 2010, 2014). For the locus of control eight items measured in 1999, 2005, 2010, 2015 are used to construct a unidimensional factor following Hennecke (2020). The following table displays the results for the reduced sample with and without controlling for traits.

Table S.8: Robustness checks - Controls for personality traits

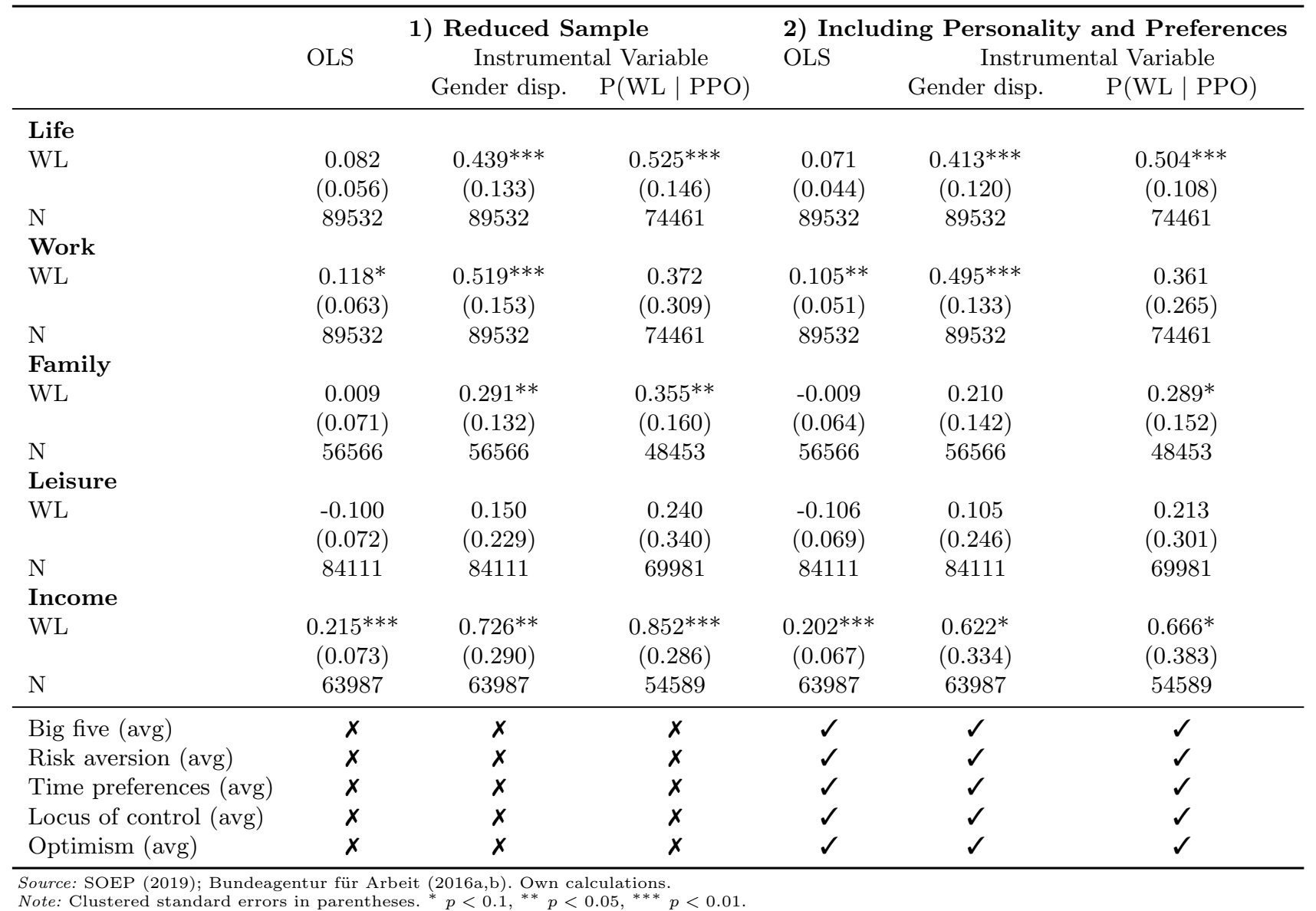

\section{References}

Bundeagentur Für ARBeit (2016a). Beschäftigte nach Berufen (KldB 2010) (Quartalszahlen) Deutschland. https://statistik.arbeitsagentur.de/DE/Navigation/Statistiken/Themen-im-Fokus/Berufe/ Berufe-Nav.html, as of March 31, 2016.

Bundeagentur Für ARBeit (2016b). Beschäftigte nach Wirtschaftszweigen (WZ 2008) (Quartalszahlen) Deutschland. https://statistik.arbeitsagentur.de/DE/Navigation/Statistiken/Themen-im-Fokus/ Wirtschaftszweige/Wirtschaftszweige-Nav.html, as of March 31, 2016.

Gerlitz, J.-Y. and Schupp, J. (2005). Zur Erhebung der Big-Five-basierten Persönlichkeitsmerkmale im SOEP. DIW Berlin Research Notes 2005(4).

Hennecke, J. (2020). The Independent Woman - Locus of Control and Female Labor Force Participation The Independent Woman - Locus of Control and Female Labor Force Participation. AUT Economics Working Paper Series 2020/03. 
Lee, D. L., McCrary, J., Moreira, M. J. and Porter, J. (2020). Valid t-ratio Inference for IV.

SOEP (2019). Socio Economic Panel Data: Data for years 1984-2018, version 35, Doi: 10.5684/soep-core.v35. 